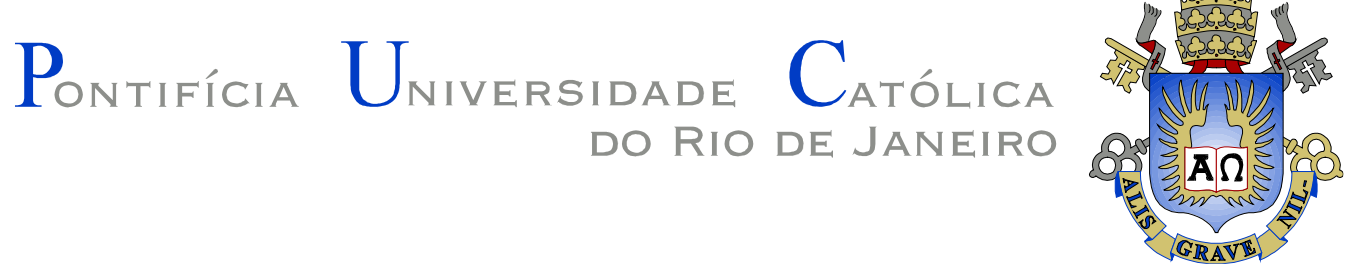

Maria de Lourdes da Fonseca Freire Norberto

Uma teologia de fronteira: a missão da Companhia de Jesus junto aos migrantes e refugiados

Dissertação de Mestrado

Dissertação apresentada ao Programa de Pós-graduação em Teologia da PUC-Rio como requisito parcial para obtenção do grau de Mestre em Teologia.

Orientadora: Prof ${ }^{\mathrm{a}}$ Maria Clara Lucchetti Bingemer 


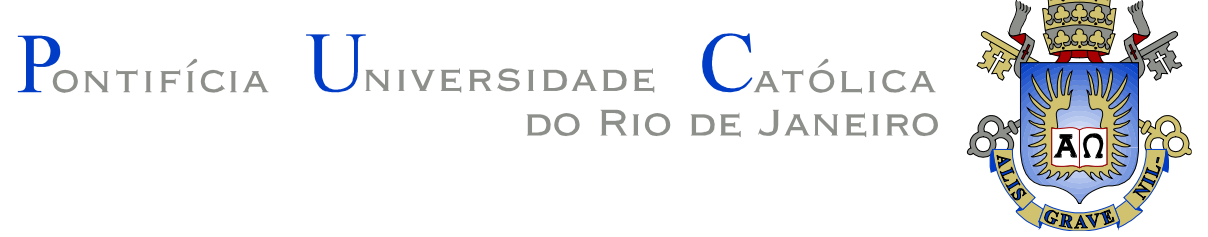

Maria de Lourdes da Fonseca Freire Norberto

\title{
Uma teologia de fronteira: a missão da Companhia de Jesus junto aos migrantes e refugiados
}

Dissertação apresentada como requisito parcial para obtenção do grau de Mestre pelo Programa de Pós-graduação em Teologia do Departamento de Teologia do Centro de Teologia e Ciências Humanas da PUC-Rio. Aprovada pela Comissão Examinadora abaixo assinada.

\author{
Profa. Maria Clara Lucchetti Bingemer \\ Orientadora \\ Departamento de Teologia - PUC-Rio \\ Prof. Paulo Fernando Carneiro de Andrade \\ Departamento de Teologia - PUC-Rio
}

Prof. Alex Villas Boas Oliveira Mariano

PUC/PR

Prof ${ }^{a}$ Monah Winograd

Coordenadora Setorial de Pós Graduação e Pesquisa do Centro de

Teologia e Ciências Humanas - PUC-Rio 
Todos os direitos reservados. É proibida a reprodução total ou parcial do trabalho sem a autorização da universidade, da autora e do orientador.

Maria de Lourdes da Fonseca Freire Norberto

Graduada em Letras, pela PUC-Rio, graduada em Comunicação Social e em Teologia pela PUCRio e com Mestrado na Faculdade de Teologia da PUC-Rio, concluído em 2018.

Ficha Catalográfica

Norberto, Maria de Lourdes da
Fonseca Freire
Uma teologia de fronteira: a missão da
Companhia de Jesus junto aos migrantes e
refugiados / Maria de Lourdes da Fonseca
Freire Norberto; orientadora: Maria Clara
Lucchetti Bingemer. - 2018.
128 f. ; $30 \mathrm{~cm}$
Dissertação (mestrado) - Pontifícia
Universidade Catolica do Rio de Janeiro,
Departamento de Teologia, 2018.
Inclui bibliografia
1. Teologia - Teses. 2. Companhia
de Jesus. 3. Missão inaciana. 4. Migrantes e
refugiados. 5. Fronteiras. I. Bingemer, Maria
Clara Lucchetti. II. Pontifícia Universidade
Católica do Rio de Janeiro. Departamento de
Teologia. III. Título.

CDD: 200 
A meu pai José (in memoriam) e a minha mãe Maria Luiza, por uma vida de amor e dedicação a nós cinco. 


\section{Agradecimentos}

A meus filhos Camila, Beatriz e André pelo amor, apoio incondicional e pela fé que depositaram em mim. Sua compreensão, incentivo e carinho foram fundamentais para que eu chegasse ao fim desta jornada.

A Maria Eduarda, minha neta muito amada, pela luz e alegria que trouxe para as nossas vidas.

A meus irmãos José Luis, Alice Maria, Camilo e Francisco José e também minhas cunhadas Maria Alice e Regina Lucia, pela presença, pelo apoio nas horas difíceis e por nunca terem deixado de acreditar em mim.

A Letícia, minha sobrinha e afilhada, por existir e ser tão querida.

A minha orientadora e professora Maria Clara Lucchetti Bingemer, não só por ter me acompanhado nesta dissertação, mas também por ter sido presença marcante e decisiva em toda a minha caminhada acadêmica desde a graduação. Sua presença e incentivo foram determinantes nos momentos de desânimo.

Aos jesuítas Alfonso Carlos Laurrari Palacio, Francisco Ivern Simó, Luis González Quevedo Tejerina e Luiz Fernando Klein pela atenção e disponibilidade em me ajudar a encontrar a bibliografia necessária para o bom êxito desta dissertação.

Aos professores e funcionários do Departamento de Teologia (Puc-Rio), pelos ensinamentos, respeito e incentivo.

A todos os amigos e colegas que, de alguma forma, me estimularam e ajudaram.

A CAPES pela concessão da bolsa durante o mestrado. 


\section{Resumo}

Norberto, Maria de Lourdes da Fonseca Freire; Bingemer, Maria Clara Lucchetti. Uma teologia de fronteira: a missão da Companhiade Jesus junto aos migrantes e refugiados. Rio de Janeiro, 2018. 128p. Dissertação de Mestrado - Departamento de Teologia, Pontifícia Universidade Católica do Rio de Janeiro.

Em "Uma teologia de fronteira: a missão da Companhia de Jesus junto aos migrantes e refugiados", procuramos mostrar a evolução do conceito de missão na fronteira dentro da Companhia de Jesus e como ela enxerga hoje essa missão. Inicialmente, fizemos um trajeto pela história das Congregações Gerais da Companhia, desde o Vaticano II, para, em seguida, analisarmos a eclesiologia do papa Francisco, jesuíta, a fim de mostrar nela a influência da visão inaciana de missão. A partir daí, estabelecemos um paralelo entre as opções missionárias do papa e as da Companhia. Devido à urgência do tema, analisamos apenas a fronteira caracterizada pelo drama dos migrantes e refugiados. Francisco trouxe a questão dos migrantes e refugiados para o centro do pensamento da Igreja e a Companhia de Jesus tem priorizado a ação junto a esta fronteira, através do Serviço Jesuíta aos Refugiados, fundado pelo padre Arrupe em 1980. Para o papa, não existe crise de refugiados e sim uma crise de solidariedade, de recusa de homens e mulheres em abrir suas portas a estes irmãos necessitados. Por isso, ele nos conclama a acolher, proteger, promover e integrar estas pessoas, através de uma "cultura do encontro" no lugar da globalização, da indiferença e das políticas de "rejeição e medo". Da mesma forma, a Companhia de Jesus entende hoje sua missão junto a esta fronteira através do SJR como uma oferta de esperança para as pessoas em total desemparo, como resposta a Jesus Cristo, que disse: "Eu era estrangeiro e vós me acolhestes (Mt 25,35)". Para concluir, fizemos uma leitura teológica do percurso por nós empreendido, buscando responder à pergunta de Deus em Gênesis 4,9: “Onde está o seu irmão?”

\section{Palavras-chave}

Companhia de Jesus; missão inaciana; migrantes e refugiados; fronteiras; 


\section{Abstract}

Norberto, Maria de Lourdes da Fonseca Freire; Bingemer, Maria Clara Lucchetti (Advisor). A theology of frontier: the Society of Jesus mission towards migrants and refugees. Rio de Janeiro, 2018. 128p. Dissertação de Mestrado - Departamento de Teologia, Pontifícia Universidade Católica do Rio de Janeiro.

In "A theology of frontier: the Society of Jesus mission towards migrants and refugees", we intend to discuss how the Jesuit concept of frontiers of mission evolved over time and how the Society of Jesus understands it nowadays. First, we studied the history of its General Congregations since Vatican II. Then, we analyzed how Pope Francis's vision of mission, as a Jesuit, influences his ecclesiology. From this point on, we established a parallel between the pope's missionary choices and those of the Society of Jesus. Due to the urgency of the matter, we focused our analysis only on the work of Jesuits with migrants and refugees, their most dramatic frontier. Pope Francis brought the issue of migrants and refugees to the center of the Church concerns and the Society of Jesus has put special emphasis on their actions with this frontier through the work of the Jesuit Refugee Service (JRS), founded by Father Pedro Arrupe in 1980. For the pope, there is no such thing as a refugee crisis. Actually, according to him, the world is facing a solidarity crisis when men and women refuse to open their doors to their brothers in need. That is why he urges all of us to welcome, protect, promote, and integrate those in need and by doing this replace the globalization of indifference and the politics of rejection and fear by the culture of encounter. Similarly, today, the Society of Jesus understands his mission in this frontier, by means of the work of the JRS, as an offer of hope for those who have been abandoned by all, as an answer to Jesus Christ words "I was a stranger and you welcomed me (Mt 25, 35). As a conclusion, we look at the path we have covered in this work from a theological perspective as we try to answer God's question in Genesis 4, 9, "Where is your brother?"

\section{Keywords}

Society of Jesus; Ignatian mission; migrants and refugees; frontiers. 


\title{
Sumário
}

\author{
1 Introdução
}

2 A Missão dos jesuítas junto às fronteiras e como ela se atualiza na história da Companhia de Jesus

2.1 A Companhia de Jesus e sua índole apostólica

2.2 As Congregações Gerais da Companhia de Jesus

e o Concílio Vaticano II

2.2.1 $31^{\text {a }}$ Congregação Geral e a missão na fronteira do ateísmo e do ecumenismo

2.2.2 32 ${ }^{\text {a }}$ Congregação Geral e a fronteira do serviço da fé e da promoção da justiça

2.2.3 33aㅡ Congregação Geral e a confirmação da missão na fronteira da fé e da justiça

2.2.4 34ํㅡㄹ Congregação Geral e a missão nas fronteiras da justiça, da cultura e do diálogo

2.2.5 35ํㅡㄹ Congregação Geral e a missão nas novas fronteiras da fé e justiça

2.2.6 36 ${ }^{\text {a }}$ Congregação Geral e a missão na fronteira da reconciliação e da justiça

3 Francisco, o primeiro papa jesuíta da história da Igreja, sua eclesiologia e seu comprometimento com a missão nas fronteiras

3.1 A pós-modernidade e a eleição de Francisco

3.2 Francisco, o papa jesuíta

3.3 A herança inaciana na eclesiologia de Francisco 57

3.3.1 Uma Igreja missionária 58

3.3.2 Um Igreja em diálogo com o mundo e com a sociedade 62

3.3.3 Uma Igreja que promove a liberdade cristã 68

$\begin{array}{ll}\text { 3.3.4 Uma Igreja voltada para os pobres } & 71\end{array}$

3.3.5 Uma Igreja que vive sua fé $\quad 76$

3.4 Considerações finais do 3ํㅗítulo $\quad 80$ 
4 A fronteira dos migrantes e refugiados e a Companhia de Jesus $\quad 83$

4.1 A questão dos migrantes e refugiados 83

4.2 O papa e os refugiados $\quad 88$

4.3 A Companhia de Jesus e a fronteira dos migrantes e refugiados 98

4.3.1 Padre Pedro Arrupe SJ e Serviço Jesuíta aos Refugiados 98

4.3.2 O Serviço Jesuíta aos Refugiados hoje 104

4.3.3 As Congregações Gerais e a SJR 109

4.4 Considerações finais do $4^{\mathrm{a}}$ capítulo 114

5 Conclusão 117

6 Referências bibliográficas 122 
Tomai, Senhor, e recebei toda a minha liberdade, a minha memória também. O meu entendimento e toda a minha vontade. Tudo o que tenho e possuo, vós me destes com amor. Todos os dons que me destes, com gratidão vos devolvo. Disponde deles, Senhor, segundo a vossa vontade. Dai-me, somente, o vosso amor, vossa graça. Isto me basta. Nada mais quero pedir. Santo Inácio de Loyola 


\section{1 \\ Introdução}

A Companhia de Jesus é uma ordem religiosa fundada, em 1534, por um grupo de estudantes da Universidade de Paris, sob a liderança do basco Inácio de Loyola, batizado com o nome de Iñigo López de Loyola. A aprovação oficial da Ordem foi declarada em 27 de setembro de 1540 pela bula Regimini Militantes Ecclesiae, assinada pelo papa Paulo III.

Em 1541, Inácio foi eleito o primeiro Superior Geral da Ordem, cargo que manteve até sua morte, em 31 de julho de 1556, em Roma, sendo canonizado em 12 de março de 1922 pelo papa Gregório XV. ${ }^{1}$

Desde o início, Inácio pensou a Companhia não como um empreendimento humano, mas sim como uma iniciativa divina, com a missão de, no seguimento de Jesus Cristo, levar sua mensagem de salvação a todos os homens.

Hoje, quando o mundo enfrenta um momento conturbado de mudança de época, chamado por muitos de pós-modernidade, a Companhia de Jesus enxerga sua missão, em fidelidade aos princípios estabelecidos por Santo Inácio, como serviço da fé e promoção da justiça. Para tal, busca, através do diálogo, restaurar a integridade e a dignidade do ser humano, reincorporando-o à sociedade e estabelecendo relações justas com Deus, uns com os outros e com a Criação.

No atual mundo, extremamente globalizado, as forças sociais, econômicas e políticas fomentaram relações construtivas entre os diversos grupos humanos, mas também criaram divisões que aumentaram drasticamente a pobreza e a exclusão, a falta de equidade e debilitaram as soberanias nacionais, empurrando milhões de pessoas para a periferia da sociedade em situação de profunda injustiça. ${ }^{2}$

A Companhia de Jesus sempre esteve comprometida com as fronteiras da sociedade, sejam elas geográficas ou existenciais, e faz parte do seu carisma ir ao encontro destas pessoas em situação de marginalização, oferecendo esperança, cuidado e solidariedade.

\footnotetext{
1 Cf. disponível em: http://www.jesuitasbrasil.com/newportal/institucional/santo-inacio-de-loyola/. Acesso em: 11 jan 2018.

2 Disponível em: http://www.itaici.org.br/companhia-de-jesus. Acesso em: 8 jan 2018.
} 
Esta dissertação tem como objetivo pesquisar a evolução do conceito de missão na fronteira, dentro da Companhia de Jesus, e como este se atualiza na contemporaneidade.

No segundo capítulo, procuramos determinar a evolução deste conceito, a partir do estudo dos decretos das Congregações Gerais da Companhia de Jesus que aconteceram após a convocação do Concílio Vaticano II, feita pelo papa João XXIII, em 25 de janeiro de 1959.

A $31^{a}$ Congregação Geral, convocada ainda durante o Concílio, já foi influenciada pelo que acontecia em Roma e coube a ela inciar o processo de adequação da Companhia e sua missão ao aggiornamento proposto pelo Vaticano II, que seria, aos longo dos anos, aperfeiçoado pelas demais congregações. Aggiornamento é um termo italiano que significa "atualização" e foi a orientação chave dada como objetivo para o Concílio. Depois da $31^{\mathrm{a}} \mathrm{CG}^{3}$, houve mais cinco congregações até a presente data, sendo que a última, a $36^{\mathrm{a}} \mathrm{CG}$, aconteceu no final de 2016, em Roma, já durante o pontificado de Francisco.

No terceiro capítulo desta dissertação, buscamos entender até que ponto a espiritualidade inaciana e o carisma da Companhia de Jesus têm influenciado a eclesiologia de Francisco, o primeiro papa jesuíta, e o que isto representa de novo para a Igreja. Para tanto, fizemos um breve relato das condições do mundo no momento em que Francisco foi eleito e elencamos algumas características próprias, oriundas de sua formação como jesuíta, que trouxe como novidade para o seu pontificado.

Em um outro momento do mesmo capítulo, a partir de um artigo de Mário de França Miranda, também jesuíta, desenvolvemos cinco elementos bem determinantes da eclesiologia de Francisco, a saber: o caráter missionário; o diálogo com o mundo; a promoção da liberdade cristã; a centralidade dos pobres; e a fé como vida. Procuramos demonstrar, através dos documentos da Companhia, como tais marcas sempre estiveram presentes na vida e no carisma da Companhia de Jesus e são determinantes, também, na vida de um jesuíta.

No quarto e último capítulo, desenvolvemos o tema da missão na fronteira dos migrantes e refugiados. Escolhemos esta fronteira como objeto de atenção especial da nossa pesquisa por vários motivos. Primeiramente, este é um tema extremamente atual, de relevância mundial que urge solução diante do sofrimento

${ }^{3}$ Nesta dissertação, usaremos CG como abreviatura para Congregação Geral. 
imposto a milhões de pessoas que não tem sequer para onde ir e nenhuma perspectiva de vida digna. Em segundo, a missão junto aos migrantes e refugiados é prioritária dentro da Companhia de Jesus, também objeto de nosso pesquisa. Além disto, esta é uma temática trazida para o centro da discussão pelo papa Francisco, não só para dentro dos muros da Igreja mas para a sociedade em geral. Desde os primeiros meses de seu pontificado, o papa está continuamente chamando a atenção para o tema e cobrando uma atitude de todos os cristãos e pessoas de boa-vontade, no sentido de se envolverem com a causa.

Começamos o capítulo 4 traçando um breve relato sobre o tema das migrações e a problemática dos migrantes e refugiados para, em seguida, tratar da ação efetiva do papa junto a esta fronteira. No momento seguinte, nos debruçamos sobre a atuação da Companhia de Jesus, através do Serviço Jesuíta ao Refugiados, fazendo uma breve retrospectiva da conjuntura política mundial desde a criação do serviço até os dias de hoje.

O Serviço Jesuíta aos Refugiados foi criado em 1980 e está intimamente ligado à figura de seu fundador, padre Pedro Arrupe, na época Superior Geral da Companhia, possuidor de carisma impressionante, que deixou uma marca indelével na história e no espírito da Companhia de Jesus. Parte deste capítulo é dedicada a ele.

Para encerrar o último capítulo, retornamos aos decretos das seis últimas Congregações Gerais, para definir como o tema específico da missão junto à fronteira dos migrantes e refugiados foi tratado por cada uma delas.

Na conclusão, procuramos estabelecer algumas raízes bíblicas presentes nas intuições de Inácio de Loyola e de tantos jesuítas que marcaram a história e o pensamento da Companhia de Jesus. A Biblia é fundamental na vida de um jesuíta e de todos que seguem a espiritualidade inaciana pois é com base na graça encontrada na Palavra de Deus, através dos Exercícios Espirituais de Santo Inácio, que é possível se traçar um caminho de oração e discernimento que permita ao exercitante configurar sua vida a de Jesus Cristo e encontrar o seu modo próprio de amar e servir a Deus no mundo.

Nosso objetivo ao fazermos esta pesquisa é chamar a atenção para o drama destas pessoas em situação de refúgio, migração e mesmo de deslocamento interno, vivendo em condições sub-humanas. Esta é uma temática atual e relevante, à qual a sociedade não pode mais se eximir de responsabilidade. É 
também objetivo nosso divulgar o trabalho da Companhia de Jesus que, dentro de suas fraquezas e limitações humanas, procura viver o ideal de Santo Inácio e, no seguimento de Jesus Cristo, levar a mensagem do Reino e a esperança cristã a todos, tentando chegar a todas as fronteiras onde o Espírito os quer levar. 


\section{2 \\ A missão dos jesuítas junto às fronteiras e como ela se atualiza na história da Companhia de Jesus}

\section{1 \\ A Companhia de Jesus e sua índole apostólica}

A Companhia de Jesus sempre se viu como uma ordem apostólica. ${ }^{4}$ De acordo com suas Constituições, discernidas por Inácio de Loyola e seus companheiros e, mais tarde, aprovadas e confirmadas pelos papas Paulo III e Júlio III em 1540 e 1550, respectivamente, a missão primeira recebida de Deus, do papa e de seus superiores é “ajudar as almas próprias e as do próximo a atingir o fim último para o qual foram criadas" ${ }^{5}$. Mais recentemente, o padre Pedro Arrupe, $28^{\circ}$ Superior Geral da Companhia, definiu os jesuítas como "homens para os outros"6, expressão repetida pelo papa Francisco em seu discurso de abertura da $36^{\mathrm{a}}$ Congregação Geral, em outubro de 2016: "O serviço do bom espírito e do discernimento torna-nos homens da Igreja - não clericalistas, mas eclesiais homens 'para os demais, sem nada próprio que isole, mas com todo o nosso ser posto em comunhão e a serviço."7

No entanto, esta missão primeira não impede que, a partir dos sinais do tempo e da história, tais missões possam ser atualizadas e novas missões possam ser discernidas, no intuito de fazer com que a Companhia tenha clareza acerca de onde seu apostolado é mais necessário ${ }^{8}$ e como ele deve ser posto em ação.

Nas últimas décadas, a sociedade e o mundo têm passado por profundas mudanças em todos os níveis da convivência humana. A partir desta nova configuração da sociedade, sempre em constante mutação, os jesuítas sentiram a necessidade de questionar as suas fronteiras tradicionais da missão, visando perceber as novas fronteiras onde são hoje instados a servir. As fronteiras da missão da Companhia não se referem somente a limites geográficos, mas incluem também as periferias existenciais. Estas fronteiras estão onde se encontra a pessoa que sofre, vítima da pobreza, da solidão, do desamparo e da degradação humana,

\footnotetext{
${ }^{4}$ Cf. BARRY e DOHERTY, Contemplativos na ação: o caminho do jesuíta, p.40.

${ }^{5}$ Constituições da Companhia de Jesus e normas complementares, Parte IV, Proêmio, n.1, p.115.

${ }^{6}$ Disponível em: https://www.biografiasyvidas.com/biografia/a/arrupe.htm Acesso em: 30 jun 2017.

7 Disponível em: http://www.jesuitasbrasil.com/newportal/2016/12/15/discurso-do-papa-franciscoaos-membros-da-36a-cg/ Acesso em: 30 jun 2017.

8 KLEIN, Jesuítas: carisma e missão. Itaici: revista de espiritualidade inaciana, n.105, 2016, p.35.
} 
que está à margem da sociedade e precisa que o cuidado, a solidariedade e a esperança cheguem a ela. E é justamente aí, nessas fronteiras, que Jesus Cristo está mais presente, convidando os jesuítas, assim como cada cristão, a colaborar no processo de renovação do mundo, ainda que dentro de suas limitações, como um espaço de justiça, igualdade, liberdade, misericórdia e perdão.

Embora a missão junto às fronteiras, sejam elas geográficas ou existenciais, tenha estado sempre presente no carisma inaciana, o termo "fronteira" só aparece nos decretos a partir da $35^{\circ}$ Congregação Geral, ocorrida em 2008, onde o tema passa a ter relevância especial.

A natureza e o carisma da Companhia de Jesus se originam e se baseiam nos Exercícios Espirituais praticados por Santo Inácio e seus companheiros. Foi sob esta forte experiência espiritual que estes homens abriram mão de sua vida anterior e formaram um grupo apostólico fundado na vivência da caridade e da pobreza que os enviou ao mundo inteiro, "para a defesa da propagação da fé e o progresso do próximo na vida e na doutrina cristã’9. Assim, é também a partir da vivência desta espiritualidade que a Companhia procura estar sempre aprofundando o conhecimento de sua própria natureza e missão se mantendo fiel à vocação inicial dos primeiros jesuítas e atenta às exigências da Igreja e às necessidades de adaptação aos sinais dos tempos, assim como às necessidades do mundo contemporâneo.

\section{2}

\section{As Congregações Gerais da Companhia de Jesus e o Concílio Vaticano II}

As Congregações Gerais são reuniões de todo o corpo da Companhia, dispersa pelo mundo inteiro, por um determinado espaço de tempo. Logicamente, não é possível que todos os jesuítas participem diretamente delas e, por isso, são escolhidos alguns para representar todos os membros do corpo. Entre estes representantes, alguns são convocados em função do cargo que ocupam e outros são eleitos por cada uma das Províncias da Companhia Universal. ${ }^{10}$

\footnotetext{
9 Constituições da Companhia de Jesus e normas complementares, Proêmio, Seção I, n.2, §1, p.233.

${ }_{10} \mathrm{Cf}$. Editorial. As Congregações Gerais e a vida, espiritualidade e missão da Companhia de Jesus. Itaici: revista de espiritualidade inaciana, n.105, 2016, p.3-4.
} 
A Congregação Geral é a instância mais alta de governo da Companhia de Jesus. Quando está em sessão, supera até a do próprio Superior Geral. Ela se reúne por dois motivos principais: a eleição do Superior Geral, em caso de doença, morte ou renúncia, e para tratar de assuntos importantes para a vida e missão da Companhia, como atestam as Constituições. ${ }^{11}$

Através do estudo dos decretos de cada uma das Congregações Gerais da Companhia de Jesus, desde a convocação do Concílio Vaticano II, podemos entender a evolução do seu projeto missionário, definindo novas fronteiras de missão ou atualizando outras nas quais os jesuítas já atuavam, sempre com o intuito de responder às necessidades de cada momento histórico. Ao percorrer este trajeto, neste segundo capítulo, é possível se perceber em que fronteiras Deus vem inspirando a Companhia, em sua caminhada histórica, a realizar sua missão apostólica.

A $31^{a}$ Congregação Geral se iniciou ainda durante o Concílio Vaticano II. De acordo com Alfonso Carlos L. Palacio, SJ, nela fez-se "a transição do pré ao pós-Concílio, i.e., realizar a renovação e adequação da missão da Companhia aos novos tempos da Igreja do Concílio e da realidade social e cultural do mundo moderno" $"$.

Para esse autor, as cinco Congregações Gerais que vieram na esteira da $31^{\mathrm{a}}$ foram imbuídas de uma mesma preocupação de expressar a vida e a missão dos jesuítas de maneira atual sem abrir mão de seu carisma específico, de sua identidade. Em consonância com as circunstâncias de seu tempo, aos poucos, essas Congregações foram gerando uma transformação de mentalidade entre os membros da Companhia, no sentido de compreender a evolução de seu conceito próprio de missão. Apesar desta unidade temática inequívoca, cada uma, principalmente no que tange às cinco últimas, acontecidas já no pós-concílio, pode ser considerada como um evento único que traz em si as marcas indeléveis do seu momento histórico. ${ }^{13}$

11 Cf. Constituições da Companhia de Jesus e normas complementares, Capítulo II n.667-681, p.193-4; n.774, p.214; n.782, p.215. Apud Editorial. As Congregações Gerais e a vida, espiritualidade e missão da Companhia de Jesus. Itaici: revista de espiritualidade inaciana, n.105, 2016, p.3-4

12 PALACIO, Recurso a Jesus Cristo e recomposição da missão da Companhia de Jesus (19652015). Itaici: revista de espiritualidade inaciana, n.99, 2016, p.21.

${ }^{13}$ Cf. ibidem. Itaici: revista de espiritualidade inaciana, n.99, 2016, p.21. 


\title{
2.2.1 \\ 31 a Congregação Geral e a missão na fronteira do ateísmo e do ecumenismo.
}

A $31^{\text {a }}$ Congregação Geral foi convocada para eleger um novo Superior Geral em função da morte do padre João Batista Janssens. O escolhido foi o padre Pedro Arrupe, natural de Bilbao, Espanha. Ela teve duas sessões: a primeira, de maio a julho de 1965, entre a terceira e a quarta sessões do Concílio Vaticano II, e a segunda, de setembro a novembro de 1966, logo após o término do Concílio. ${ }^{14}$ A maior parte dos decretos foi aprovada na segunda fase e a influência do Concílio se faz sentir por todo o documento, além de serem muitas as referências à Constituição Pastoral Gaudium et Spes e ao Decreto Conciliar Ad Gentes, que trata da atividade missionária da Igreja. ${ }^{15}$

As duas sessões aconteceram em Roma, durante o pontificado de Paulo VI. Em sua exortação, o papa sublinha a importância da Companhia para Igreja, reafirmando sua sabedoria, seu conhecimento dos problemas e espírito de inciativa $^{16}$ e conclamando os jesuítas à ação apostólica, seguindo as determinações de sua Constituição que diz:

\begin{abstract}
(...) que cada um de nós e todos que para o futuro fizerem a profissão, além dos três votos comuns, se liguem com outro particular de obediência ao atual Santo Padre e aos outros Sumos Pontífices que para o futuro o forem, em tudo o que nos ordenarem para proveito das almas e dilatação da fé. E assim fiquemos obrigados a ir, quanto está na nossa mão, para quaisquer províncias aonde nos quiserem mandar, sem demora, subterfúgio ou escusa. ${ }^{17}$
\end{abstract}

A $31^{a}$ CG não havia sido inicialmente convocada para tratar da renovação e modernização da Companhia. No entanto, como pouco tempo depois da convocação o Concílio solicitou a todas as instituições de vida religiosa que se reunissem para tratar desses dois temas, a Congregação assumiu também esta temática, além da eleição do novo Superior Geral. Para Urbano Valero Agundez, SJ, o ambiente de renovação geral no qual a Igreja estava imersa em função do que acontecia no Vaticano, somado ao momento de mudança que a humanidade

\footnotetext{
14 Cf. AGUNDEZ, El proyecto de renovación da la Companhia de Jesús (1965-2007), p.35 (todas as citações deste livro são traduções nossas).

15 Cf. IVERN, A missão da Companhia de Jesus da Congregação Geral 31 até os nossos dias. Itaici: revista de espiritualidade inaciana, n.105, 2016, p.7.

${ }^{16} \mathrm{Cf}$. Congregação Geral XXXI, Exortação do papa Paulo VI, n.11, p.12.

17 Constituições da Companhia de Jesus e normas complementares. Form. Inst. Julio III, n. 1. Apud Congregação Geral XXXI, Exortação do papa Paulo VI de 7 de maio de 1965, n.17, p.14.
} 
estava vivendo não podiam ser ignorados pela CG. Esse ambiente, inclusive, já havia sido percebido pelas congregações provinciais e mesmo por muitos jesuítas que, individualmente ou em grupo, haviam se antecedido e solicitado a revisão de vários pontos da vida e do apostolado da Companhia, no sentido de adaptá-los aos novos tempos. ${ }^{18}$

A $31^{\text {a }} \mathrm{CG}$ reafirma o caráter apostólico da Companhia de Jesus que, desde seu início, esteve "intimamente associada ao mandato missionário universal de toda a Igreja"19. Embora se refira à ação missionária em várias frentes, há, neste documento, uma ênfase na missão na fronteira do ateísmo. A missão que ali se destaca é o combate ao mesmo ${ }^{20}$.

Em consonância com o Concílio, os padres congregados reconheceram estar diante de um mundo transformado social e culturalmente, em função da crescente industrialização, da urbanização da sociedade e do fenômeno cada vez mais acentuado da "intercomunicação", já presente naquela época, ${ }^{21}$ que favorecia o crescimento do ateísmo e da indiferença religiosa, ${ }^{22}$ além de impor dificuldades à evangelização. Em função disto, recomendaram um esforço redobrado dos jesuítas na evangelização, citando o próprio Concílio Vaticano II: “na situação atual da humanidade, em que surgem estas novas condições de existência, a Igreja, sal da terra e luz do mundo, é mais instantemente chamada a acudir à salvação e renovação de toda a criatura." 23

O próprio papa Paulo VI, em seu discurso inaugural, solicitou à Companhia que fizesse do combate ao ateísmo uma de suas tarefas prioritárias, com as seguintes palavras:

À Companhia de Jesus, cuja missão específica é defender a Igreja e a religião quando os tempos são mais difíceis, confiamos o encargo de reunir todas as suas forças para se opor eficazmente ao ateísmo (...) presente no mundo nos nossos dias,

\footnotetext{
18 Cf. AGUNDEZ, El proyecto de renovación da la Companhia de Jesús (1965-2007), p.35.

19 Congregação Geral XXXI, Dec. 24, n.2, p.195.

20 Apesar de ter como missão o combate ao ateísmo, há também, no texto do Decreto da $31^{\text {a }}$ CG, uma preocupação com o ecumenismo, já como influência das ideias inovadoras trazidas pelo Concílio que acontecia em Roma. Karl Rahner, presente no Vaticano II, contribuiu de forma decisiva para o diálogo ecumênico no pós-concílio com sua tese dos "cristãos anônimos" que defendia que as religiões não-cristãs podiam ser "vias legítimas de salvação".

${ }^{21}$ Cf. IVERN, A missão da Companhia de Jesus da Congregação Geral 31 até os nossos dias. Itaici: revista de espiritualidade inaciana, n.105, 2016, p.7.

22 Cf. Congregação Geral XXXI, Dec. 1, n.1, p.29.

${ }^{23}$ Ad Gentes, Decreto sobre a Atividade Missionária da Igreja, n.1. Apud Congregação Geral XXXI, Dec. 24, n.3, p.195.
} 
umas vezes abertamente e outras encoberto debaixo de aparências de progresso na cultura, na economia e no social. ${ }^{24}$

O Decreto, depois de fazer uma breve descrição da situação do mundo, pedia que todos os membros da Companhia, independente da missão em que estivessem envolvidos, procurassem estar atentos aos ateus e agnósticos e conhecer mais de perto a questão, tanto em relação ao ateísmo como à indiferença religiosa ${ }^{25}$.

Em atendimento à essa solicitação do Paulo VI e considerando o Concílio que convocou a Igreja a ser "sal da terra e luz do mundo"26 diante da constatação do crescimento do ateísmo na sociedade moderna, a Companhia colocou, após séria análise e reflexão, a missão nessa fronteira como tarefa prioritária ${ }^{27}$, procurando instar os jesuítas a buscarem possíveis causas do ateísmo, suas motivações e refletir sobre as dificuldades na ação apostólica e possíveis formas de atuação. ${ }^{28}$

Para o papa, esta era uma empreitada importante e, para que os jesuítas percebessem a urgência do tema, convocou-os à ação já na sua Exortação, dizendo:

combatam este combate, sem nada deixarem de organizar para conseguir bom êxito, investiguem, recolham informações de todo o gênero, imprimam o que for conveniente, discutam entre si, preparem especialistas, orem fervorosamente, deem testemunho de justiça e santidade..$^{29}$

Uma outra preocupação dos padres congregados foi o ecumenismo. Até aquele momento, a Companhia nunca havia se debruçado especificamente sobre este tema. No entanto, por influência direta do Concílio Vaticano II, principalmente a partir de seus documentos Unitatis Redintegratio, Orientalium Ecclesiarum e Dignitatis Redintegratio, concluiu-se que era chegado o momento de dar ênfase ao tema e mudar sua orientação em relação às igrejas separadas. De acordo com o Decreto da $31^{\mathrm{a}} \mathrm{CG}$, não havia como negar a participação importante dos jesuítas na Contrarreforma e a necessidade de um mea-culpa pelos erros, limitações, fragilidades e faltas cometidas contra a unidade da Igreja, tanto no

${ }^{24}$ Congregação Geral XXXI, Exortação do papa Paulo VI de 7 de maio de 1965, n.13 e 14, p.13-4.

${ }^{25} \mathrm{Cf}$. Congregação Geral XXXI, Dec. 3 n.2.

${ }^{26}$ Ad Gentes, n.1. Apud Congregação Geral XXXI, Dec. 24, n.3, p.195.

${ }^{27}$ IVERN, A missão da Companhia de Jesus da Congregação Geral 31 até os nossos dias. Itaici: revista de espiritualidade inaciana, n.105, 2016, p.7.

${ }^{28} \mathrm{Cf}$. Congregação Geral XXXI, Dec. 3, n.2, p.30.

29 Idem, n.14 a 16. 
passado como também mais recentemente. Os padres congregados reconheceram a necessidade de virar a página tridentina e a assumir a página que o Vaticano II acabara de escrever com verdadeiro sentido ecumênico, ${ }^{30}$ recomendando aos jesuítas atenção "a algumas recomendações e orientações práticas que se hão de aplicar tendo em conta a preparação de cada um, as circunstâncias locais e sobretudo as determinações da Hierarquia"31.

De acordo com Luis Fernando Klein, SJ, além da missão na fronteira do ateísmo e do ecumenismo, $31^{\text {a }} \mathrm{CG}$ apontou outras fronteiras de atuação apostólica que, devido às urgentes questões do mundo contemporâneo, necessitavam também da atualização e do revigoramento estimulados pelo Concílio e solicitou atenção especial por parte dos jesuítas a seis delas: 1) o mundo da cultura superior, destacando-se as ciências positivas que promovem a investigação científica e técnica; 2) o setor do trabalho e dos grupos profissionais, dando especial atenção aos mais desfavorecidos; 3) a formação da juventude, em especial a que oferece mais esperança de liderança na Igreja e no mundo; 4) as instituições internacionais que procuram promover a união no mundo; 5) alguns lugares que, por excessivo crescimento demográfico, rápida evolução social, econômica e política sofrem embates de ordem física e moral e 6) os neopagãos, que foram contagiados pelo ateísmo teórico ou prático. ${ }^{32}$

Essa CG reconheceu, em seu texto, a necessidade da experiência dos Exercícios Espirituais para o desempenho das missões. É esta vivência espiritual, que é graça de Deus, que leva os jesuítas a estarem sempre se renovando para, através da união apostólica, reforçada pelos votos de pobreza, castidade e obediência, poderem se colocar a serviço da Igreja pela mediação do Sumo Pontífice. ${ }^{33}$ Ainda segundo os padres congregados, Santo Inácio, ao fundar a Companhia, a animou da força interna dos Exercícios de forma que ela pudesse, ao longo da história, cumprir as exigências da sua vocação e missão. ${ }^{34}$

$\mathrm{Na}$ Introdução ao Decreto 14, intitulado “Oração", os padres congregados afirmam que os Exercícios Espirituais são escola de oração e oração apostólica e é deles que deve sair o apóstolo da Companhia chamado a ser contemplativo na

\footnotetext{
${ }^{30}$ Cf. Congregação Geral XXXI, Dec. 26, Introdução, p.203-4.

31 Congregação Geral XXXI, Dec. 26, Introdução, p.205.

32 Idem, Dec. 21, n.11, apud KLEIN, Jesuítas: carisma e missão. Itaici: revista de espiritualidade inaciana, n.105, 2016, p.36-7.

${ }^{33}$ Cf. idem, Dec. 1, apud ibidem, p.37.

${ }^{34}$ Cf. idem, Dec. 1, n.4, p.21.
} 
ação. Pela vivência dos Exercícios, o jesuíta aprende a viver no mundo de hoje, se mantendo em íntima união de oração e de ação, encontrando Deus em todas as coisas:

Dos Exercícios Espirituais, que são escola de oração e de oração apostólica, deve sair o apóstolo da Companhia que esta chamado a ser contemplativo na ação. Neles, o jesuíta aprende a viver, no mundo de hoje, esta íntima união de oração e de lição da escola de oração dos Exercícios Espirituais. ${ }^{35}$

De acordo com o Decreto, a íntima união com Cristo, a vida de oração e de serviço apostólico não podem andar separadas. Todas essas facetas da vida do jesuíta constituem uma só união indivisa que permite que a ação receba a força e a luz da oração e que a oração impulsione a ação. ${ }^{36}$

O padre Arrupe, na carta que escreveu aos jesuítas em 2 de janeiro de 1967, poucos meses após o término da $31^{\mathrm{a}} \mathrm{CG}$, recomendou aos jesuítas a prática dos Exercícios Espirituais de Santo Inácio. Para ele, os Exercícios são o requisito fundamental necessário para renovar e potencializar a capacidade pessoal de cada um para a missão. Ainda segundo ele, quando o Concílio pediu a todos os institutos religiosos um retorno à fonte, para a Companhia não tratava simplesmente da recuperação de documentos originais nos quais foram plasmados sua essência e seu projeto original e, sim, do retorno à experiência espiritual mesma como foi vivida por Inácio e seus companheiros através dos Exercícios. Segundo ele, só assim o jesuíta de hoje teria condições de viver seu carisma próprio naquele momento da história. ${ }^{37}$

\subsection{2}

\section{2ª Congregação Geral e a fronteira do serviço da fé e da promoção da justiça}

A $32^{\mathrm{a}}$ Congregação Geral aconteceu oito anos depois da anterior e teve a duração de 3 meses, entre $1^{\circ}$ de dezembro de 1974 e 7 de março de 1975 . Sua convocação não se deu por força de afastamento ou morte do Superior Geral, mas por determinação do próprio padre Arrupe, com parecer favorável dos Superiores e das Congregações Provinciais, para levar adiante o processo de renovação

\footnotetext{
${ }^{35}$ Congregação Geral XXXI, Decreto 14, Introdução, p.105.

36 Idem, Decreto 14, n.4, p.108-9.

37 Cf. AGUNDEZ, El proyecto de renovación de la Compañia de Jesus (1965-2007), p.136-7.
} 
proposto e estimulado pelo Concílio, prosseguindo, assim, na atualização de aspectos da vida e da missão dos jesuítas após o Vaticano II. ${ }^{38}$ De acordo com U. V. Agundez, SJ, esta Congregação Geral foi preparada com muito cuidado, de forma ampla e aberta e gerou muitas expectativas e temores. As expectativas eram as mais variadas possíveis frente às propostas de aprofundamento e renovação da Companhia de Jesus. Já os temores estavam ligados a possíveis mudanças que poderiam desfigurar a índole e o caráter original da Companhia. ${ }^{39}$

A $32^{\text {a }}$ CG aconteceu em Roma, ainda durante o pontificado de Paulo VI, que veio a falecer poucos anos depois, em 6 de agosto de 1978. O discurso de abertura do papa, em 3 de dezembro de 1974, antes mesmo do início das sessões, já apresentava um programa de trabalho bem elaborado. Depois de formular e responder a três perguntas fundamentais acerca do "ser" da própria Companhia “de onde vindes?", “quem sois?” e “aonde vais?”, o papa resumiu o seu próprio discurso $^{40}$ :

\begin{abstract}
Ao terminarmos este encontro, julgamos ter-vos dado algumas indicações acerca do caminho que deveis percorrer no mundo hodierno; e quisemos também indicarvos o caminho do mundo futuro. Conhecei-o, aproximai-vos dele, servi-o, amai este mundo; em Cristo, ele será vosso. Olhai-o com os mesmos olhos com que Santo Inácio olhou, adverti as mesmas exigências espirituais, usai as mesmas armas; oração, procurando sempre Deus e a Sua glória, prática da ascética, disponibilidade absoluta. Pensamos não exigir demasiado ao exprimirmos o desejo de que a Congregação aprofunde os "elementos essenciais da vocação jesuítica, de modo que todos os vossos irmãos se possam reconhecer neles, retemperar ali o seu próprio compromisso, redescobrir a sua própria identidade, voltar a sentir a sua vocação, refundir a própria união comunitária. O momento presente exige-o; a companhia espera uma palavra decisiva. Não deixeis de a proferir. ${ }^{41}$
\end{abstract}

Ao contrário da Congregação Geral que a precedeu, e que publicou vários pequenos decretos acerca de diversos apostolados, a $32^{\mathrm{a}} \mathrm{CG}$, no que tange à missão apostólica, produziu apenas um único documento, o Decreto 4, intitulado "A nossa missão nos dias de hoje: diaconia da fé e promoção da justiça", fora outros dois mais breves que se referiam à vida religiosa e ao apostolado da Companhia de Jesus, chamados respectivamente de "O jesuíta hoje" e “Aculturação da fé e promoção da vida cristã".

38 Cf. KLEIN, Jesuítas: carisma e missão. Itaici: revista de espiritualidade inaciana, n.105, 2016, p.33.

39 Cf. AGUNDEZ, El proyecto de renovación da la Compañia de Jesus (1965-2007), p.163.

40 Cf. ibidem, loc. cit.

${ }^{41}$ Congregação Geral XXXII, Alocução do Santo Padre de 3 dezembro, 1974, n.22, p.217-8. 
Com o Decreto 4, na visão de Francisco Ivern Simó, SJ, que participou da $32^{\mathrm{a}}$ CG e fez parte da comissão de redação ${ }^{42}$, os padres congregados não pretenderam propor metas definidas para serem atingidas num determinado período de tempo por todos os jesuítas, seja individual ou comunitariamente. O que a Congregação realmente pretendeu foi simplesmente propor alguns objetivos e critérios gerais que inspirassem e guiassem a missão do jesuíta e convidassem a Companhia a entrar em um processo de avaliação apostólica, discernimento e mudança em função desses objetivos e critérios, considerando as diferenças entre indivíduos, províncias e países. ${ }^{43}$

Este decreto teve um impacto enorme, que se faz sentir até hoje, mas também deu margem a diversas interpretações, muitas vezes distorcidas e incorretas e que geraram, nos anos seguintes, debates e divisões entre os jesuítas, principalmente na América Latina e entre aqueles ligados ao apostolado educacional e social. ${ }^{44}$

A $32^{\mathrm{a}}$ Congregação, a partir do Decreto 4 , tratou primordialmente do serviço junto à fronteira da fé e da promoção da justiça. A formulação básica da missão da Companhia, naquele momento, foi discernida pelos jesuítas como "o serviço da fé, da qual a promoção da justiça é uma exigência absoluta"45. Para L. F. Klein, embora a fé e a justiça tenham sempre se constituído como fronteira de missão da Companhia, naquele específico momento, se tornaram de suma importância frente às aspirações e expectativas da humanidade. ${ }^{46}$

A Companhia percebeu, nos sinais dos tempos, a necessidade de ajudar "os homens a se abrirem a Deus e viverem segundo as dimensões e exigências do Evangelho" 47 , através do reconhecimento, do respeito e da promoção eficaz do direito e da dignidade de todos, especialmente dos mais pequenos e fracos. ${ }^{48}$

\footnotetext{
42 IVERN, Serviço da fé e promoção da justiça continua sendo nossa missão hoje. Nota de página. Itaici: revista de espiritualidade inaciana, n.5, p.37.

43 IVERN, The Future of Faith and Justice: a Critical Review of Decree Four. Studies in the Spirituality of Jesuits, n.5, v.XIV, 1982. Introdução do autor, p.1 (todas as traduções desse artigo são nossas).

${ }^{44}$ Cf. idem. A missão da Companhia de Jesus da Congregação Geral 31 até os nossos dias. Itaici: revista de espiritualidade inaciana, n.105, 2016, p.9.

45 AGUNDEZ, El proyecto de renovación da la Compañia de Jesus (1965-2007), p.177.

46 Cf. KLEIN, Jesuítas: carisma e missão. Itaici: revista de espiritualidade inaciana, n.105, 2016, p.37.

47 Congregação Geral XXXII, Decreto 4, n.18.

48 Cf. idem, loc. cit.
} 
De acordo com esse decreto, a pregação do Evangelho precisa estar necessária e concomitantemente atrelada ao exercício e à luta pela justiça ${ }^{49}$, pois:

não há conversão autêntica no amor de Deus sem conversão no amor dos homens e, consequentemente, às exigências da justiça. A própria fidelidade da missão apostólica requer, portanto, que proponhamos a salvação integral, quer dizer, que, em primeiro lugar, devemos introduzir os homens no amor do Pai, e, por Ele, no amor do próximo e da justiça. A evangelização é proclamação da fé que opera no amor aos homens: não se pode realizar a sério sem promoção da justiça. ${ }^{50}$

Para Klein, o fato da $32^{\mathrm{a}}$ Congregação Geral enfatizar o serviço da fé e da promoção da justiça não implica em um rompimento com as propostas da Congregação anterior. Muito pelo contrário, ela se coloca como continuidade e aprofundamento do combate ao ateísmo, conforme solicitado pelo papa Paulo VI à $31^{\mathrm{a}} \mathrm{CG} .{ }^{51}$ Segundo esse autor, os padres congregados estabeleceram um paralelo entre a ignorância ou a resistência à proposta do Evangelho e o recrudescimento das injustiças em tantas situações e lugares do mundo contemporâneo e constataram que "não há conversão autêntica ao amor de Deus sem conversão ao amor dos homens e, consequentemente, às exigências da justiça" ${ }^{\text {, }}$, tornando-se assim imprescindível pregar o Evangelho de forma concomitante e relacionada à justiça. ${ }^{53}$

Como na Congregação anterior, a 32 $\mathrm{CG}$ afirma a importância dos Exercícios Espirituais na missão do jesuíta. Segundo ela:

é traço característico da pedagogia dos Exercícios Espirituais procurar afastar os obstáculos entre Deus e o homem, para deixar o Espírito operar Ele próprio o encontro. Esta pedagogia inaciana convida a respeitarmos cada um, com a sua cultura, as suas qualidades próprias e as tradições que o ajudaram a tornar-se aquilo que é. Essa pedagogia apresenta-se, além disso, como pedagogia de busca e de discernimento; ela ensina a descobrir a vontade e os caminhos de Deus, ali onde Ele interpela a cada um com o seu passado, no coração mesmo da vida, no povo que é seu.

Os Exercícios Espirituais podem também ajudar a formar cristãos capazes de se alimentarem duma experiência pessoal de Deus Salvador e de se manterem longe dos falsos absolutos das ideologias e dos sistemas, comprometendo-se nas reformas estruturais, sociais e culturais necessárias. ${ }^{54}$

49 Cf. KLEIN, Jesuítas: carisma e missão. Itaici: revista de espiritualidade inaciana, n.105, 2016, p.38.

50 Congregação Geral XXXII, Decreto 4, n.28.

51 Cf. KLEIN, Jesuítas: carisma e missão. Itaici: revista de espiritualidade inaciana, n.105, 2016, p.37.

52 Congregação Geral XXXII, Decreto 4, n.18.

${ }^{53}$ Cf. KLEIN, op. cit., p.38.

54 Congregação Geral XXXII, Decreto 4, n.57-58. 
Assim sendo, os Exercícios Espirituais, de acordo com essa Congregação, conservam sua atualidade e são de grande valor para os jesuítas. A $32^{\mathrm{a}}$ Congregação estimulou, por isso, estudos no sentido de redescobrir seu dinamismo próprio e atualizá-los para o nosso tempo, adaptando-os às novas necessidades. ${ }^{55}$

\subsection{3 \\ 33ª Congregação Geral e a confirmação da missão na fronteira da fé e da justiça}

A $33^{\text {a }}$ Congregação Geral aconteceu entre 2 de setembro e 25 de outubro de 1983 e foi a mais breve de todas as seis Congregações após o Concílio Vaticano II: durou apenas 54 dias. ${ }^{56} \mathrm{Um}$ de seus objetivos principais foi a renúncia de Arrupe e a eleição de seu sucessor. Essa Congregação, convocada em circunstâncias muito especiais, aconteceu em Roma, durante o pontificado de João Paulo II. Paulo VI havia morrido em agosto de 1978, tendo sido sucedido por João Paulo I, que faleceu um mês depois. João Paulo II foi eleito em outubro, tornandose o terceiro papa a governar a Igreja no segundo semestre de 1978.

Em 1980, padre Arrupe já havia pensado em convocar uma Congregação Geral para apresentar seu pedido de renúncia. Já estava com 73 anos, mas, a pedido do papa João Paulo II, adiou esta convocação para que houvesse mais tempo para a preparação da $33^{a}$ Congregação. No entanto, em 7 de agosto de 1981, sofreu um derrame muito grave $\mathrm{e}^{57}$ que o impediu de ficar à frente da Companhia e o papa, então, nomeou o padre Paolo Dezza para o substituir interinamente e preparar a próxima Congregação. ${ }^{58}$ Assim, quase três anos depois, em 13 de setembro de 1983, o padre Peter-Hans Kolvenback, natural de Dutren, Países Baixos, tornou-se o Superior Geral como sucessor do padre Arrupe, que morreria em 5 de fevereiro de $1991 .^{59}$

Essa Congregação aconteceu oito anos e meio depois da $32^{\mathrm{a}} \mathrm{CG}$ e nela, além de eleger o Superior Geral, os padres congregados refletiram atentamente sobre o estado da Companhia naquele momento. Foi produzido apenas um decreto ${ }^{55}$ Cf. Congregação Geral XXXII, Dec. 14, n.3.

${ }^{56}$ Congregação Geral XXXIII, Proêmio histórico extraído das Atas da Congregação Geral XXXIII, n.24.

${ }^{57}$ ECHAVIZ, Paixão e Glória: História da Companhia de Jesus em corpo e alma. Tomo IV, p.377-8.

58 Congregação Geral XXXIII, Proêmio histórico extraído das Atas da Congregação Geral XXXIII, n.1, p.1.

${ }_{59}$ Cf. ECHAVIZ, op. cit., p.381. 
bem amplo, o de número 1, intitulado "Companheiros de Jesus enviados ao mundo hoje" que englobava diversos temas, relativos à vida espiritual, pessoal e comunitária do jesuíta e também à missão naquele momento histórico. Esse decreto foi complementado por alguns outros poucos sobre questões particulares. De acordo com U. V. Agundez, não houve, nessa Congregação, uma abordagem verdadeiramente nova do projeto de renovação da Companhia, iniciado e ampliado pelas duas últimas Congregações. ${ }^{60}$ São palavras da própria CG $33^{\text {a }}$ :

Cremos que hoje é mais necessário por em prática as determinações anteriores do que produzir longas declarações ou novos decretos. Com efeito, "o amor consiste mais em obras do que em palavras". Por isso, a $33^{\text {a }}$ CG limitou-se a tratar das questões que pareciam mais urgentes e de algumas de caráter jurídico que lhe tinham sido encomendadas. ${ }^{61}$

Para o autor, essa Congregação representou uma confirmação do desenho da Companhia formulado pelas anteriores, retificando e equilibrando alguns aspectos práticos que necessitavam de revisão. Isto não significa que a $33^{\mathrm{a}} \mathrm{CG}$ tenha sido uma congregação revisionista, apesar de ter reconhecido erros e falhas cometidos na aplicação das duas Congregações que a precederam imediatamente e de ter também feito correções, retificando o rumo indicado pelas anteriores sem se afastar da proposta por elas feitas. ${ }^{62}$

$\mathrm{Na}$ visão de Agundez, a $33^{\mathrm{a}} \mathrm{CG}$ foi, em síntese, um eco fiel, mas não puramente repetitivo, das suas duas predecessoras, particularmente a $32^{\mathrm{a}}$, confirmando expressamente o legado de ambas. Ela não trouxe elementos realmente novos para o projeto renovado da Companhia, mas há, no decreto principal, um claro esforço em atualizar, concretizar e tornar mais compreensíveis e acessíveis alguns pontos substanciais do seu texto e iluminar, com indicações claras e expressivas, as ações a serem postas em prática naquele momento, particularmente em referência à missão. ${ }^{63}$

L. F. Klein afirma que houve, nessa Congregação, um profundo empenho em revisar as experiências da missão realizadas a partir do Concílio Vaticano II, no sentido de dar uma resposta a pedidos de dentro da própria Companhia e também às intervenções do papa João Paulo II, relativas às interpretações e

60 Cf. AGUNDEZ, El proyecto de renovación da la Compañia de Jesus (1965-2007), p.229-30.

${ }^{61}$ Congregação Geral XXXIII, Dec. 1, n.4, p.46-7.

62 Cf. AGUNDEZ, op. cit, loc. cit.

63 Ibidem, loc. cit. 
práticas unilaterais do Decreto da $32^{\mathrm{a}} \mathrm{CG}$ sobre o serviço da fé e a promoção da justiça. ${ }^{64} \mathrm{O}$ próprio Arrupe havia reconhecido que a interpretação deste decreto podia ter sido, às vezes, "truncada, unilateral ou pouco equilibrada"65.

Em relação à missão, a $33^{\mathrm{a}} \mathrm{CG}$ reafirmou a necessária integração do serviço da fé e da promoção da justiça em uma única missão, que deve permear todos os ministérios da Companhia. Ao fazer isto, consequentemente, reafirmou também a relevância da missão na fronteira da fé e da promoção da justiça, ${ }^{66}$ já defendida pelo Decreto 4 da Congregação Geral anterior, segundo o qual a justiça é "exigência absoluta" do próprio serviço da fé, a missão primeira da Companhia. ${ }^{67}$

Para Klein, o decreto da $33^{\mathrm{a}} \mathrm{CG}$ definiu que a missão na fronteira do serviço da fé e da justiça não se restringe a um ministério ou a um tipo específico de apostolado. Ela é muito mais abrangente e precisa levar em conta muitos fatores negativos que existem entremeados a ideologias e sistemas políticos, econômicos, sociais e culturais. Essas ideologias, a seu ver, geram um materialismo difuso, um ateísmo prático, crise de fé, desrespeito pela dignidade humana e agressão ao meio ambiente. Diante deste quadro, a $33^{\mathrm{a}} \mathrm{CG}$ sentiu a necessidade de um processo de reavaliação para chegar à compreensão renovada da missão fundamental da Companhia, como definida na Fórmula do Instituto, que é a salvação integral das pessoas. ${ }^{68}$

Ainda segundo Klein, por este motivo, a $33^{\mathrm{a}}$ Congregação confirmou a anterior ao definir o binômio "fé e justiça" como fator integrativo que não pode faltar a qualquer ação apostólica a ser realizada, afirmando que

o serviço da fé e a promoção da justiça não se justapõem, nem muito menos se opõem, antes exprimem um único compromisso, que tem sua raiz profunda e seu princípio unificador na força do amor a Deus e ao próximo, ao qual o Senhor nos chama no seu grande mandamento. ${ }^{69}$

64 Cf. KLEIN, Jesuítas: carisma e missão. Itaici: revista de espiritualidade inaciana, n.105, 2016, p.39.

65 ARRUPE, Charitate radical e fundati, 67 (AR XVIII - 1981, n.465). Apud Congregação Geral XXXIII, Decreto 1, n.32.

66 Cf. IVERN,A missão da Companhia de Jesus da Congregação Geral 31 até os nossos dias. Itaici: revista de espiritualidade inaciana, n.105, 2016, p.9.

67 Congregação Geral XXXIII, Proêmio histórico extraído das Atas da Congregação Geral XXXIII, n.22.

68 KLEIN, op. cit., p.39.

${ }^{69}$ Congregação Geral XXXIII, Homilia do Santo Padre o papa João Paulo II na abertura da XXXIII Congregação Geral, n.6. 
Essa Congregação também enfatizou a missão nas fronteiras do ecumenismo, o aprofundamento dos estudos sobre as relações com as religiões não cristãs, o diálogo da Igreja com a cultura e o processo de inculturação, segundo solicitação feita pelo papa João Paulo II, na homilia da missa inaugural:

(...) renovo este convite, a adaptar às diferentes necessidades espirituais de hoje "as diferentes formas de apostolado tradicional que mantêm ainda hoje todo o seu valor" e a prestar cada vez maior atenção "às iniciativas que o Concílio Vaticano II particularmente animou", tais como o ecumenismo, o aprofundamento do estudo sobre as relações com as igrejas não cristãs, e o diálogo da Igreja com as culturas. A este respeito, conheço e aprovo o vosso empenho pela inculturação, tão importante para a evangelização, desde que seja acompanhada de igual empenho por conservar a doutrina católica pura e íntegra. ${ }^{70}$

Além disso, o Decreto 1 da CG também elenca algumas situações e necessidades que deveriam ser vistas como objeto de especial consideração: (1) a indigência espiritual de muitos, especialmente dos jovens que buscam sentido de vida; (2) a violação dos direitos humanos por regimes autoritários, que incluem assassinatos, prisões, torturas, privação da liberdade religiosa ou da livre opção política; (3) a situação de milhões de refugiados; (4) o tratamento injusto e os abusos contra a mulher; e (5) a opressão econômica e carência espiritual de desempregados, camponeses privados de terra e operários. ${ }^{71}$

Há também uma menção explícita aos pobres e a opção preferencial por eles. De acordo com o documento, essa opção deve ser expressa de forma direta ou indireta na vida de cada jesuíta, na orientação e na escolha das missões, pois "somente na medida em que vivermos nossa consagração ao Reino em comunhão, isto é, com os pobres, em favor deles e contra toda a pobreza humana material e espiritual, é que o pobre verá abrir-se para ele as portas do Reino"72.

Como as anteriores, a $33^{\mathrm{a}} \mathrm{CG}$ também reafirma a importância dos Exercícios Espirituais na missão da Companhia, na medida em que eles convidam os jesuítas a "olhar[em] o mundo com o olhar amoroso das Três Pessoas Divinas"73 e assim, seguindo orientação do papa no seu discurso de abertura, perceberem as necessidades dos homens como Deus as percebe e, então, se

\footnotetext{
70 Congregação Geral XXXIII, Homilia do Santo Padre o papa João Paulo II na abertura da XXXIII Congregação Geral, n.6, p.91.

${ }^{71}$ Cf. idem, Dec. 1, n. 45, p.67-8.

72 Idem, Dec. 1, n.48, p.69-70.

73 Congregação Geral XXXIII, Homilia do Santo Padre o papa João Paulo II na abertura da XXXIII Congregação Geral, Dec. 1, 2ª parte, n.34.
} 
colocarem a serviço do seu plano de salvação, que já começa na vida presente e que atinge sua plenitude na vida eterna. ${ }^{74}$

O Decreto 1 lembra que, graças à nova consciência da vida religiosa na Companhia despertada pelos decretos das últimas duas Congregações e também aos escritos do padre Arrupe, houve no período pós-Concílio uma renovação da espiritualidade inaciana que se manifesta, sobretudo, no novo impulso dado aos Exercícios Espirituais e ao discernimento apostólico. O compromisso pela fé e pela justiça, mais o serviço aos pobres e a participação em suas vidas tornaram-se um apelo a todo o corpo da Companhia para assumir um modo de vida mais evangélico. ${ }^{75}$

\subsection{4 \\ 34a Congregação Geral e a missão nas fronteiras da justiça, da cultura e do diálogo}

A $34^{\mathrm{a}}$ Congregação Geral, que durou três meses e meio, aconteceu no período entre 5 de janeiro e 22 de março de 1995, doze anos depois da anterior. Ela foi convocada por livre iniciativa do Superior Geral, padre Kolvenbach, para examinar e eventualmente aprovar a proposta de revisão das Constituições da Ordem, pedida pela Congregação anterior e elaborada durante os anos que se seguiram. Teve também, como outro objetivo, a confrontação da Companhia com os novos desafios externos e internos que se colocavam à sua frente. ${ }^{76}$

Essa Congregação aconteceu em Roma e o papa que a presidiu foi João Paulo II. Em seu discurso inaugural, em consonância com as preocupações do Superior Geral já citadas, disse:

Esta vossa Congregação Geral reveste, sem dúvida, uma importância particular no atual momento histórico, sendo consagrada essencialmente a discernir a contribuição específica que vosso Instituto é chamado a oferecer à nova Evangelização no limiar do terceiro milênio cristão, e atualizar a organização e a legislação da Companhia de Jesus, para prestar um serviço cada vez mais adequado e fiel à Igreja. ${ }^{77}$

\footnotetext{
${ }^{74}$ Cf. idem, p.92.

75 Cf. Congregação Geral XXXIII, Homilia do Santo Padre o papa João Paulo II na abertura da XXXIII Congregação Geral, Dec. 1, n.10, p.49.

${ }^{76}$ Cf. AGUNDEZ, El proyecto de renovación da la Compañia de Jesus (1965-2007), p.229-30.

77 Decretos da Congregação Geral XXXIV, Discurso de Sua Santidade o papa João Paulo II, n.2. p.308.
} 
De acordo com Kolvenbach, o projeto de revisão das Constituições da Companhia de Jesus a ser aprovado iria requerer dos padres congregados um grande esforço de fidelidade ao carisma apostólico que sempre fundamentou a legislação da Companhia, mas também de abertura às demandas dos novos tempos. Serviria de impulso renovador na promoção da liberdade apostólica, da responsabilidade pessoal e da solidariedade, elementos necessários para a missão do jesuíta nas novas contingências históricas. ${ }^{78}$

As fronteiras de ação priorizadas nessa CG foram definidas em quatro documentos que tratavam especificamente da missão. O primeiro foi o Decreto 2, mais geral, intitulado "Servidores da missão de Cristo", onde está delineada a orientação atualizada da missão da Companhia. Os outros três foram o Decreto 3, "Nossa missão e a justiça", o Decreto 4, "Nossa missão e a cultura" e o Decreto 5, "Nossa missão e o diálogo inter-religioso"79. Esses decretos visavam estimular a Companhia no correto desempenho da missão pela fé e a justiça, esclarecendo os termos e as dimensões integrais desse binômio como já proposto nas Congregações anteriores. ${ }^{80}$

Para U. V. Agundez, a diferença entre a proposta da dessa CG e as anteriores é que, enquanto as $32^{\mathrm{a}}$ e $33^{\mathrm{a}}$ CGs estavam mais focadas em uma reformulação da Companhia que permitisse que fosse colocada a "serviço da fé e cultura", a 34 CG, por sua vez, à parte a revisão das Constituições, se empenhou em explicitar a missão dentro de uma visão integral e integrada, que respondesse aos desafios que se colocavam naquele determinado momento. ${ }^{81}$

Para Klein, houve também um alargamento dos limites da missão na fronteira da justiça. Enquanto nas duas predecessoras, a ênfase foi dada na justiça como promoção da paz, reconciliação, a não violência, as discriminações e clamorosa pobreza, a 34 $\mathrm{CG}$ acrescentou a estas, também, a promoção e a defesa das pessoas e dos seus direitos, as consequências maléficas da globalização e da homogeneização econômica e cultural e, finalmente, a preservação do meio ambiente. $^{82}$

${ }^{78}$ Cf. KOLVENBACH, Carta a toda a Compañia, de 27 de septiembre 1992, versión espanhola, AR XX. Apud AGUNDEZ, El proyecto de renovación da la Compañia de Jesus (1965-2007), p.247-8.

${ }^{79}$ Cf. Decretos da Congregação Geral XXXIV, Dec. 1, n.1.

80 Cf. KLEIN, Jesuítas: carisma e missão. Itaici: revista de espiritualidade inaciana, n.105, 2016, p.40.

81 AGUNDEZ, op. cit., p.256.

82 Cf. KLEIN, Jesuítas: carisma e missão. Itaici: revista de espiritualidade inaciana, n.105, 2016, p.41. 
Ainda de acordo com esse autor, em referência aos erros e excessos cometidos na interpretação e aplicação do Decreto 4 da $32^{\mathrm{a}} \mathrm{CG}$ e também em atenção aos sinais dos tempos, a $34^{\mathrm{a}}$ Congregação Geral sentiu que era necessário priorizar a estreita relação que deve haver entre a noção de justiça e Evangelho, que vai além de qualquer ideologia, filosofia, enfoque ou opção política. ${ }^{83} \mathrm{Na}$ visão de F. Ivern, no sentido de priorizar esta relação, os padres congregados compreenderam a importância de reafirmar a necessidade da promoção da justiça estreitamente unida a sua dimensão cultural e religiosa, concluindo pela inseparabilidade de justiça, diálogo e evangelização, missão única que deveria permear todos os ministérios da Companhia. ${ }^{84}$

O Decreto 2 da $34^{\mathrm{a}} \mathrm{CG}$, em consonância com o Decreto 4 da $32^{\mathrm{a}} \mathrm{CG}$, afirma que a missão junto ao serviço da fé e da promoção da justiça do Reino de Deus não pode prescindir do diálogo e da inserção na cultura. A fé que busca a justiça é inseparavelmente a fé que dialoga com outras religiões e a fé que evangeliza a cultura. Nele se afirma:

Não pode haver serviço da fé sem promover a justiça, entrar nas culturas, abrir-se a outras experiências religiosas. Não pode haver promoção da justiça sem comunicar a fé, transformar as culturas, colaborar com as outras tradições. Não pode haver enculturação sem comunicar a fé aos outros, dialogar com outras tradições, comprometer-se com a justiça. Não pode haver diálogo religioso sem partilhar a fé com outros, valorizar as culturas, interessar-se pela justiça. ${ }^{85}$

O Decreto 3 da $34^{\mathrm{a}} \mathrm{CG}$ vai tratar especificamente da relação entre fé e justiça, tema central nas $32^{\mathrm{a}}$ e $33^{\mathrm{a}}$ CGs. De acordo com esse documento, "a luta pela justiça tem caráter progressivo, evoluindo gradual e historicamente conforme se confronte com as necessidades cambiantes deste ou daquele povo, cultura e época" ${ }^{86}$.

Em função deste caráter progressivo da luta pela justiça, a Companhia foi tomando consciência de outras fronteiras onde se sentiu chamada a atuar frente à situação crítica em que se encontravam e que atingia, já naquela época, centenas de milhões de pessoas, tais como a marginalização da África; o colapso dos sistemas totalitários da Europa do Leste, que deixou em ruínas todas as áreas da

\footnotetext{
83 Ibidem, p.41.

84 IVERN, A missão da Companhia de Jesus da Congregação Geral 31 até os nossos dias. Itaici: revista de espiritualidade inaciana, n.105, 2016, p.11.

85 Decretos da Congregação Geral XXXIV, Decreto 2, n.18, p.65.

86 Idem, Decreto 3, n.5.
} 
vida humana de sua população; os povos indígenas e alguns segmentos de outras culturas, como os dalits indianos, marginalizados e discriminados socialmente, inclusive pela Igreja; e os mais de 44 milhões de refugiados e migrantes, já na época dessa Congregação, dos quais $80 \%$ eram mulheres e crianças. Também foram citados pelo Decreto, como uma dessas novas fronteiras de atuação, os milhões de pessoas excluídas pelas forças econômicas e sociais dos países ditos desenvolvidos, entre eles os desempregados, os jovens sem possibilidade nenhuma de entrar no mercado de trabalho, as crianças em situação de rua, exploradas e abandonadas, os idosos solitários e sem proteção social, os expresidiários, vítimas do abuso de álcool e drogas, doentes de Aids e outros mais. ${ }^{87}$

Já o Decreto 4 tratou especificamente da relação entre fé e cultura, chamando a atenção para os elementos da cultura da época em que $34^{\mathrm{a}} \mathrm{CG}$ aconteceu. Concluiu que justiça, diálogo e evangelização da cultura são fronteiras de missão inseparáveis. ${ }^{88}$

De acordo com esse documento, a inseparabilidade da justiça, do diálogo e da cultura tem base na mística que flui da experiência de Santo Inácio. As atividades apostólicas da Companhia não podem colocar em oposição Deus e o mundo e sim colocar Deus no mundo, trabalhando para levá-lo à plenitude, de modo que o mundo chegue a ser plenamente em Deus. ${ }^{89}$ De acordo com o padre Arrupe:

(...) enculturação é a encarnação da vida e mensagem cristãs numa área cultural concreta, de sorte que esta experiência não somente chegue a expressar-se como os elementos próprios da cultura em questão (o que não passaria de adaptação superficial), mas se converta no princípio inspirador, normativo e unificador que transforme e recrie esta cultura dando origem a "uma nova criação". 90

Para F. Ivern, a $34^{\mathrm{a}} \mathrm{CG}$ convidou os jesuítas a procurarem as raízes dos problemas que a sociedade enfrentava não só na área socioeconômica e sociopolítica, mas também levando em consideração as suas raízes culturais e religiosas e os valores que inspiram e sustentam as estruturas sociais, as instituições e os estilos de vida das sociedades. Convidou-os também a analisar os

87 Cf. Decretos da Congregação Geral XXXIV, Decreto 4, n.11-16, p.72-74.

88 Cf. KLEIN, Jesuítas: carisma e missão. Itaici: revista de espiritualidade inaciana, n.105, 2016, p.41.

${ }^{89}$ Cf. Exercícios Espirituais 235-237. Apud Decretos da Congregação Geral XXXIV, Decreto 4, n.7, p.83.

90 ARRUPE, Carta e documento sobre a inculturação, AR 17 (1978). Apud Decretos da Congregação Geral XXXIV, Decreto 4, n.13, p.87. 
símbolos, as representações, os valores e contravalores que orientam e governam suas vidas, o que pensam e são como indivíduos e como comunidades, assim como a forma como entendem e praticam a fé..$^{91}$

Este decreto lembra também a centralidade do mistério pascal que ilumina toda a história humana, atingindo toda religião, cultura e ser humano e não somente os cristãos, e afirma que "Cristo Ressuscitado está atuando constantemente em todas as dimensões da história humana, em sua diversidade de culturas e de experiências espirituais". ${ }^{92}$

Os padres congregados também trataram da missão na fronteira da cultura pós-moderna. De acordo com eles, o diálogo com culturas é um diálogo especialmente difícil pelo fato dos parceiros interlocutores considerarem o cristianismo ou qualquer outro compromisso religioso algo superado. Ao se lidar com a cultura pós-moderna, estas mesmas premissas precisam ser levadas em consideração. ${ }^{93}$

Assim, uma evangelização inculturada em um ambiente pós-moderno não significa uma secularização ou diluição da mensagem cristã para possibilitar uma acomodação a este novo horizonte e sim a introdução da possibilidade e da realidade de Deus através do testemunho e do diálogo baseado "no respeito e na amizade e da experiência compartilhada de cristãos e não crentes numa cultura secular e crítica"94. Este diálogo tem que estar baseado em "partilha de vida, compromisso comum na ação em favor dos direitos humanos e da libertação, na partilha de valores e da experiência humana" ${ }^{95}$.

O Decreto 5 da $34^{\mathrm{a}} \mathrm{CG}$ tratou também da relação entre fé e diálogo interreligioso como uma fronteira de missão e não como um recurso à conversão. De acordo com este decreto, "a cultura do diálogo deveria se tornar-se uma característica distintiva da Companhia" ${ }^{\circ 6}$ e um elemento integrante da identidade do jesuíta, "pois ser religioso hoje equivale a ser inter-religioso" $"$.

Para F. Ivern, por este documento, a Companhia foi convocada a superar preconceitos e mal-entendidos e também a se capacitar para o diálogo com outras

91 Cf. IVERN, A missão da Companhia de Jesus da Congregação Geral 31 até os nossos dias. Itaici: revista de espiritualidade inaciana, n.105, 2016, p.11.

92 Cf. Decretos da Congregação Geral XXXIV, Decreto 4, n.15-16, p.88-9.

${ }^{93}$ Cf. idem, Decreto 4, n.19, p.90.

94 Idem, Decreto 4, n.22-23, p.91- 2.

95 Id., Decreto 4, n.23, p.92.

${ }^{96}$ Cf. Decretos da Congregação Geral XXXIV, Decreto 5, n.17.

97 Cf. idem, loc.cit. Apud KLEIN, Jesuítas: carisma e missão. Itaici: revista de espiritualidade inaciana, n.105, 2016, p.41. 
religiões a partir de quatro pontos: diálogo da vida, da ação, da experiência religiosa e do intercâmbio teológico. Na visão dos padres congregados, o diálogo e o intercâmbio não se limitam a temas de natureza doutrinária ou de experiência religiosa, mas também abraçam a religião como um fator que modela a existência humana e contribui, seja positiva ou negativamente, para o progresso das pessoas e das comunidades e seu desenvolvimento integral. ${ }^{98}$

Há, no Decreto 5, uma ênfase no diálogo com o povo judeu, o povo da primeira aliança, "nunca revogada" "99; com o islamismo, uma força religiosa, política e econômica crescente em nossos dias, mesmo em países cristãos ocidentais; com os hindus, grupo religioso cujas práticas dão margem a uma interlocução fecunda; e com o budismo, com suas riquezas contemplativas. Esse documento também apresenta uma preocupação com o fundamentalismo presente em todas as religiões usado como força de manipulação de interesses de poderes políticos, econômicos, culturais e étnicos, convidando os jesuítas a procurarem caminho para diálogo e reconciliação para lidar com os fundamentalistas. ${ }^{100}$

A $34^{\text {a }}$ Congregação, no seu Decreto 5, também tratou, pela primeira vez na história da Companhia de Jesus, da questão socioambiental, colocando-a no contexto do compromisso pela promoção da justiça. ${ }^{101} \mathrm{O}$ documento diz que a participação do jesuíta "na promoção da justiça se realiza num mundo em que os problemas de injustiça, exploração e destruição do meio ambiente adquiriram dimensões globais" "102. Para Ivern, já havia, neste momento, na Companhia, uma consciência da íntima relação que existe entre o problema ambiental e a promoção da justiça. A Congregação, nessa ocasião, também solicitou ao Superior Geral que fosse feito um estudo sobre o tema. Tal estudo foi publicado quatro anos depois, com o título "Vivemos num mundo fragmentado: reflexões sobre a ecologia"103.

Como nas Congregações anteriores, a importância dos Exercícios Espirituais na vida do jesuíta perpassa todo o texto do Decreto da $34^{\mathrm{a}}$ CG. De acordo com Carlos Palacio, essa Congregação remonta à experiência dos

98 Cf. IVERN, A missão da Companhia de Jesus da Congregação Geral 31 até os nossos dias. Itaici: revista de espiritualidade inaciana, n.105, 2016, p.11.

99 João Paulo II: Alocução à comunidade judaica (Mainz, 17 novembro, 1980), AAS 73,1981 n.80, Apud Decretos da Congregação Geral XXXIV, Decreto 5, n.12, p.111.

100 Decretos da Congregação Geral XXXIV, Decreto 5, n.12-16, p.111-4.

101 Cf. IVERN, A missão da Companhia de Jesus da Congregação Geral 31 até os nossos dias. Itaici: revista de espiritualidade inaciana, n.105, 2016, p.13.

102 Decretos da Congregação Geral XXXIV, Decreto 5, n.8, p.105.

103 Cf. IVERN, A missão da Companhia de Jesus da Congregação Geral 31 até os nossos dias. Itaici: revista de espiritualidade inaciana, n.105, 2016, p.13. 
Exercícios e dos primeiros companheiros para afirmar a vocação e o carisma da Companhia em estar com Cristo, como servidores da sua missão. ${ }^{104}$

\section{2 .5 \\ 35ª Congregação Geral e a missão nas novas fronteiras da fé e justiça}

A 35a Congregação Geral aconteceu no período 7 de janeiro a 6 de março de 2008, com o objetivo primeiro de eleger o sucessor de Kolvenbach, que havia solicitado renúncia por força de sua idade, e também para tratar de assuntos internos da Companhia. ${ }^{105} \mathrm{O}$ novo Superior Geral eleito foi o padre Adolfo Nicolás, natural de Villamuriel de Cerrato, Espanha. Essa Congregação aconteceu em Roma, durante o pontificado de Bento XVI, durou dois meses e produziu seis decretos. ${ }^{106}$

Pela primeira vez, aparece nos textos de uma Congregação o uso do termo “fronteira”. Neste momento, na visão de Klein, a missão passou a receber uma nova denotação, a de ir às fronteiras físicas, sociais, culturais e religiosas, "aonde outros não vão ou não sabem como ir e aí atuar"107, como afirmou o próprio papa em seu discurso inicial, lembrando as seguintes palavras do papa Paulo VI, por ocasião da $32^{\mathrm{a}}$ Congregação Geral:

Onde quer que, na Igreja, mesmo nos campos mais difíceis e de ponta, nas encruzilhadas das ideologias, nas trincheiras sociais, existiu e existe confronto entre as exigências candentes do homem e a mensagem perene do Evangelho, lá estiveram e lá estão os jesuítas. ${ }^{108}$

O papa, nesse discurso, além de ratificar a missão definida pelas Congregações anteriores, nas fronteiras da fé e da promoção da justiça e da opção pelos pobres, recordando sua base cristológica também confessou a expectativa da Igreja quanto à atuação competente e perseverante dos jesuítas que vinham, ao longo dos últimos anos, alargando, de forma considerável, os horizontes de sua atuação apostólica ${ }^{109}$

\footnotetext{
104 Cf. PALACIO, Recurso a Jesus Cristo e recomposição da missão da Companhia de Jesus (1965-2015). Itaici: revista de espiritualidade inaciana, n.99, 2016, p.27.

105 Cf. Decretos da 35a Congregação Geral, Proêmio histórico, n.1, p.13.

106 KLEIN, Jesuítas: carisma e missão. Itaici: revista de espiritualidade inaciana, n.105, 2016, p.42.

107 Decretos da 35a Congregação Geral, Alocução do Santo Padre aos membros da 35a Congregação Geral, p.282.

108 Ibidem, loc. cit.

109 KLEIN, Jesuítas: carisma e missão. Itaici: revista de espiritualidade inaciana, n.105, 2016, p.42.
} 
A $35^{\mathrm{a}} \mathrm{CG}$, em resposta ao papa, em seu Decreto 1, intitulado "Com renovado impulso e vigor, a Companhia de Jesus responde ao convite de Bento XVI", conclamou os jesuítas a se tornarem agentes, promotores de comunhão, de interação num mundo conturbado, intransigente e nada pacífico, ${ }^{110}$ se tornando "pontes de compreensão e de diálogo num mundo fragmentado"111 "pela globalização e pela pós-modernidade" ${ }^{112}$.

Os padres congregados identificaram, nessa ideia de mundo fragmentado, várias pobrezas existentes a partir de relações injustas que se estabeleceram entre os seres humanos e acabaram por gerar antagonismo entre ricos e pobres, entre os que têm o poder e os que encontram dificuldade em fazer ouvir os seus interesses. ${ }^{113}$ Neste contexto, percebendo a importância da palavra "reconciliação" no decreto sobre os "Desafios para a nossa missão hoje: enviados às fronteiras", a $35^{\text {a }}$ Congregação, segundo F. Ivern, propõe uma tríplice resposta apostólica aos desafios do mundo contemporâneo: ${ }^{114}$ a reconciliação com Deus, especialmente através dos Exercícios Espirituais, a reconciliação com os outros, de modo particular os pobres e marginalizados, e também a reconciliação com a natureza, a partir de uma responsabilidade ecológica efetiva.

O papa Bento VXI aponta para esta questão no seu discurso inicial:

A Vossa Congregação desenrola-se num período de grandes mudanças sociais, econômicas e políticas; de acentuados problemas éticos, culturais e ambientais, de conflitos de todo gênero; mas também de comunicações mais intensas entre os povos, de novas possibilidades de conhecimento e de diálogo, de profundas aspirações à paz. São situações que interpelam profundamente a Igreja Católica e a sua capacidade de anunciar aos nossos contemporâneos a Palavra de esperança e de salvação. Faço vivos votos, portanto, de que toda a Companhia de Jesus, graças aos resultados desta Congregação, possa viver, com renovado impulso e fervor, a missão para a qual o Espírito a suscitou na Igreja, e a conservou, desde há mais de quatro séculos e meio, com extraordinária fecundidade de frutos apostólicos. ${ }^{115}$

A $35^{\mathrm{a}} \mathrm{CG}$, em relação às novas fronteiras que se apresentam, teve plena consciência de que para servir à missão de Cristo, naquele momento, era preciso pensar a missão em contexto global, de um mundo interligado e em constante

\footnotetext{
110 Cf. ibidem, loc. cit.

111 Decretos da 35ª Congregação Geral. Decreto 13, n.1.

112 Idem, Dec. 3, n.17, p.114.

${ }_{113}$ Cf. idem, Dec. 3, n.28, p.120.

114 IVERN, A missão da Companhia de Jesus da Congregação Geral 31 até os nossos dias. Itaici: revista de espiritualidade inaciana, n.105, 2016, p.14.

115 Cf. Decretos da 35a Congregação Geral, Alocução do Santo Padre aos Membros da 35a Congregação Geral, p.282.
} 
mutação. A globalização, a tecnologia e os problemas ambientais desafiaram as fronteiras originais de missão e as ampliaram, exigindo, com isto, que os jesuítas e todas as pessoas de boa vontade se unissem e se comprometessem com o bemestar do mundo inteiro e com um desenvolvimento de modo sustentável e gerador de vida. Nestas circunstâncias, se tornou imprescindível que todos trabalhassem cada vez mais em conjunto, para que todos os seres humanos pudessem viver e prosperar juntos, sem exclusão, discriminação e opressão. ${ }^{116}$ Só assim seria possível ao jesuíta resgatar sua missão original de levar a salvação a todos.

Diante disso, os padres congregados, no Decreto 3, apesar de reconhecerem as prioridades provinciais e regionais, elencaram algumas preferências apostólicas que requeriam uma atenção especial ou privilegiada da Companhia, entre elas a África e a China, o apostolado intelectual, as instituições interprovinciais em Roma e os migrantes. ${ }^{117}$

Em relação à África e Madagascar, afirmaram a responsabilidade da Companhia na apresentação de uma visão mais integral e humana deste continente a partir da consciência das enormes diferenças culturais, sociais e econômicas. Para responder a esta responsabilidade, o documento conclamou os jesuítas a uma maior solidariedade, com apoio efetivo à missão de inculturar a fé e promover mais justiça.

Em relação à China, propuseram um diálogo respeitoso, conscientes da importância desse país para a paz no mundo e do grande potencial para enriquecer a sua tradição de fé uma vez que "muitos de seus habitantes desejam um encontro espiritual com Deus, em Cristo"118.

O apostolado intelectual se tornou de importância vital diante dos desafios complexos e inter-relacionados que os jesuítas têm que enfrentar num mundo tão globalizado e, ao mesmo tempo, fragmentado. Esse apostolado era, na ocasião, um meio privilegiado que a Companhia dispunha para responder adequadamente à contribuição intelectual à qual os jesuítas são chamados. O desempenho desta nova dimensão da missão exigia que os jesuítas se preparassem para tal e este esforço os levou a se dedicarem também a outras fronteiras de ação, como a pesquisa intelectual e o diálogo com a contemporaneidade, com a cultura e com as religiões.

116 Cf. Decretos da 35a Congregação Geral, Dec. 2, n.20-22, p.91-2.

117 Cf. idem, Dec. 37-40, p.124-7.

118 Idem, Dec. 3, n.39, p.126. 
As instituições interprovinciais em Roma são uma missão especial da Companhia, recebida do papa e, portanto, como afirmam as Constituições, devem ser tratadas "como as mais importantes" mais frutos, os padres congregados propuseram uma planificação estratégica e uma avaliação continuada das instituições e da Companhia.

Por fim, foi chamada a atenção para a situação dos refugiados e para o fenômeno da migração forçada por diferentes razões e que, já naquela época, estava aumentando consideravelmente, gerando grande sofrimento a milhões de pessoas. A Congregação reafirmou a preferência de ação apostólica junto a esta fronteira, no sentido de atender às necessidades desses migrantes, incluindo os refugiados, os deslocados internos e as vítimas do tráfico de pessoas. ${ }^{120}$

O problema socioambiental, já abordado pela congregação anterior, foi novamente tema da $35^{\text {a }}$ Congregação. No Decreto 2, os padres congregados conclamaram os jesuítas a se voltarem para fronteira da terra, saindo do espaço da dúvida e da indiferença, assumindo a responsabilidade pelo planeta, ${ }^{121}$ a nossa casa, "cada vez mais degradada e saqueada"122 que pedia "um espaço para viver e respirar" ${ }^{123}$. No texto, destaca-se que "o cuidado do meio ambiente afeta a qualidade de nossas relações com Deus, com os outros seres humanos e com a própria Criação" ${ }^{24}$.

O Decreto lembra que a pressão para ter acesso às fontes de energia e a outros recursos naturais, e também para explorá-los, já estava aumentando com enorme rapidez a deterioração do planeta, a ponto de ameaçar a vida como um todo. As consequências da poluição, do desmatamento, do aumento de depósitos de resíduos tóxicos, na época, já eram responsáveis por mortes e enorme sofrimento, principalmente nas camadas mais pobres da população mundial. Diante disto, os padres congregados convidaram os demais jesuítas e pessoas de boa vontade a promoverem "estudos e práticas centrados nas causas da pobreza e na melhoria do meio ambiente" ${ }^{125}$.

\footnotetext{
119 Constituições, 603, 8. Apud Decretos da 35a Congregação Geral, Dec. 3, n.39, p.126.

120 Cf. Decretos da 35ª Congregação Geral, Dec. 3, n.31, p.122.

121 Cf. idem, loc. cit.

122 Idem, Dec. 2, n.23, p.94.

123 Idem, loc. cit.

124 Idem, Dec. 3, n.32, p.122.

125 Decretos da 35 ${ }^{\underline{a}}$ Congregação Geral, Dec. 3, n.34 e 35, p.122-3.
} 
E, mais uma vez, citando o discurso de Bento XVI, afirmou-se a importância e a necessidade dos Exercícios Espirituais de Santo Inácio, cujo ministério deve ocupar um lugar de destaque na vida de cada jesuíta:

Para sermos verdadeiros, "contemplativos na ação", buscando e encontrando, de fato, Deus em todas as coisas, é necessário que voltemos, uma e outra vez, à experiência espiritual do Exercícios Espirituais. Por serem "um dom do Espírito" que o Senhor deu a toda a Igreja, segundo o apelo do Santo Padre, devemos prestar atenção especial ao ministério dos Exercícios Espirituais. ${ }^{126}$

O Decreto 2 desta CG afirma que a raiz da identidade do jesuíta está em Jesus Cristo. "Estar com Cristo no coração do mundo"127, como propôs a Congregação, é uma experiência fundamental para a vida e a missão de cada membro da Companhia: A partir da contemplação de Jesus Cristo, cada jesuíta aprende a olhar mundo como Ele o faz e é assim gradualmente introduzido em uma nova forma de vida. ${ }^{128}$ De acordo com o Dec. 2 , esta experiência não é apenas "um alicerce que se lançou no passado e se esquece com o passar do tempo, mas algo vivo, continuado, alimentado pela dinâmica da vida do jesuíta em comunidade e em missão"129.

\subsection{6 \\ 36 Congregação Geral e a missão na fronteira da reconciliação e da justiça}

A $36^{a}$ Congregação Geral da Companhia de Jesus se reuniu, em Roma, sob o pontificado de Francisco, primeiro papa jesuíta na história da Igreja. Essa foi a primeira vez que a Companhia de Jesus, reunida em uma congregação se viu face a face com um papa que associava, na sua pessoa, o ser jesuíta e ser Vigário de Cristo $^{130}$. Essa congregação aconteceu no período de 2 de outubro a 12 de novembro de 2016, durante seis semanas. O objetivo dessa congregação foi a eleição do Superior Geral, em substituição a Adolfo Nicolás, que solicitou sua renúncia por motivo de saúde. O eleito foi padre Arturo Soza, natural de Caracas, Venezuela, que se tornou o primeiro Padre Geral não europeu.

\footnotetext{
126 Idem, Dec. 1, n.12, p.61.

127 Idem, Dec. 2, n.3.

128 Cf. PALACIO, Recurso a Jesus Cristo e recomposição da missão da Companhia de Jesus (1965-2015). Itaici: revista de espiritualidade inaciana, n.99, 2016, p.29.

${ }^{129}$ Decretos da 35a Congregação Geral, Dec. 2, n.4, p.78.

130 Cf. PALACIO, "Fazer-se ao largo" na vida e na missão. Itaici: revista de espiritualidade inaciana, n.107, 2016, p.5.
} 
Além da escolha do novo Prepósito Geral, os padres congregados também discutiram os novos desafios que o mundo enfrenta, traçando estratégias para a Companhia de Jesus, tanto para o futuro imediato como para longo prazo.

No discurso que fez aos padres congregados, em 24 de outubro, o papa confirmou as palavras de Paulo VI e João Paulo II, dizendo que a Igreja precisa dos jesuítas e continua confiando na Companhia, de maneira especial, para alcançar os lugares físicos e espirituais onde outros não conseguem chegar ou têm dificuldade para fazê-lo. Em seguida, instou os jesuítas a caminharem sempre rumo às fronteiras físicas e existenciais onde os outros não alcançam. ${ }^{131}$

No Decreto 1, intitulado "Companheiros na missão de Reconciliação e Justiça", já se pode perceber a centralidade do tema da reconciliação como fronteira de missão, em consonância com a $35^{a}$ Congregação, que, por sua vez, ampliou a mensagem contida no Decreto $4, n .2$ da $32^{\mathrm{a}} \mathrm{CG}$ que afirmava que "a missão da Companhia de Jesus, hoje é o serviço da fé, do qual a promoção da justiça constitui uma exigência absoluta enquanto faz parte da reconciliação dos homens, exigida pela reconciliação dos mesmos com Deus"132.

Há, neste documento, uma introdução do serviço da fé e a promoção da justiça, os elementos centrais da missão conforme as últimas CGs, no esquema da "reconciliação": é o "ministério da reconciliação que Deus começou em Cristo"133. Através deste ministério, Deus convida os jesuítas e os demais a participar na obra de reconciliação que Ele realiza no mundo ferido. ${ }^{134}$

Esse decreto recorda que a humanidade está vivendo uma crise única, que abrange tudo que nos envolve. Citando o papa Francisco, afirma que "não há duas crises separadas, uma ambiental e outra social e, sim, uma só e completa crise socioambiental" ( $L S$ n.139). Essa crise, segundo o documento, tem origem no modo como os seres humanos usam e abusam da população e das riquezas da terra. Para os padres congregados, essa crise possui profundas raízes espirituais que minam a esperança e alegria que Deus nos oferece pelo Evangelho e também afeta tanto a Igreja como a Companhia de Jesus. Diante disso, e conscientes de sua missão, os padres congregados conclamam todos os jesuítas a colaborarem

\footnotetext{
131 Disponível em: http://www.jesuitasbrasil.com/newport.al/2016/12/15/discurso-do-papa-franciscoaos-membros-da-36a-cg/ Acesso em: 30 jun 2017.

132 Congregação Geral XXXII, Dec. 4, n.2, p.37.

133 Congregação Geral XXXVI, Dec. 1, n.2-3.

134 Cf. PALACIO, "Fazer-se ao largo" na vida e na missão. Itaici: revista de espiritualidade inaciana, n.107, 2016, p.16.
} 
com a obra de Deus no mundo, através do grande ministério de reconciliação que começou em Cristo e se realiza no Reino de justiça, paz e integridade da criação. ${ }^{135}$

Em função disto, o Decreto 1 retoma as três dimensões da missão na fronteira da reconciliação definidas pela congregação anterior, procurando atualizá-las em função da urgência dos novos tempos. São elas: a reconciliação com Deus, a reconciliação de um com os outros e a reconciliação dos seres humanos com a criação. ${ }^{136}$

A reconciliação com Deus, de acordo com o documento, enraíza o jesuíta na gratidão e o abre à alegria. Citando o papa Francisco, os padres congregados afirmam que "a alegria do Evangelho enche o coração e a vida inteira daqueles que se encontram com Jesus (...) Com Jesus Cristo renasce sem cessar a alegria” (EG n.1). A missão primeira da Companhia, de acordo com eles, é anunciar e compartilhar o Evangelho, para que Jesus seja conhecido e possa se tornar fonte de alegria, esperança e vida para todos os seres humanos.

Esse decreto esclarece que a proclamação do Evangelho acontece em contextos culturais muito diferentes. Em alguns, o desafio está na secularização, que exige criatividade para atrair as pessoas, especialmente os jovens. Em outros, o desafio está em responder efetivamente às dúvidas dos fiéis que abandonam a Igreja por não encontrar nela o sentido que buscam para suas vidas. Em função desta realidade, os padres congregados convidam os demais jesuítas a valorizar os estudos teológicos e bíblicos para poderem acompanhar cada povo a partir de suas mais profundas tradições espirituais. ${ }^{137}$

A reconciliação da humanidade, de acordo com a $36^{\mathrm{a}} \mathrm{GG}$, convida os jesuítas a refletir sobre os relatos de sofrimento e injustiça pelos quais passam milhões de pessoas no mundo e os convoca, no seguimento de Cristo, à missão na fronteira da justiça e da paz, servindo os pobres e excluídos e ajudando a construir a paz. O documento enfatiza o serviço aos refugiados e aos marginalizados.

Em relação aos refugiados e migrantes, há um convite à promoção de uma cultura de hospitalidade. Já em relação aos marginalizados pela injustiça e desigualdade, há um convite à defesa e promoção dos direitos humanos destes grupos. O documento indica, entre estes grupos marginalizados, os povos e

135 Congregação Geral XXXVI, Dec. 1, n.2-3, p.37.

${ }^{136}$ Cf. idem, Dec 1, n.21-30, p.45-50

137 Cf. Congregação Geral XXXVI, Dec. 1, n.22-24, p.46. 
comunidades indígenas, enfatizando como exemplo paradigmáticos os dalits e as tribos da Ásia Meridional. Cita também as mulheres, que devem ser apoiadas em suas lutas e no reconhecimento de seus valores e coragem.

O documento também chama a atenção para o fundamentalismo e para os conflitos étnicos, religiosos e políticos que são fonte de intolerância e violência a partir de convicções religiosas deformadas. ${ }^{138}$

A $36^{a}$ Congregação, citando a Carta Encíclica Laudato Si, chama a atenção para a conexão fundamental que existe entre a crise ambiental e a crise social pela qual a humanidade passa atualmente. São do papa Francisco, as seguintes palavras:

Não há duas crises separadas: uma ambiental e outra social; mas uma única e complexa crise socioambiental. As diretrizes para a solução requerem uma abordagem integral para combater a pobreza, devolver a dignidade aos excluídos e, simultaneamente, cuidar da natureza. ( $L S$ n.139)

Diante desta constatação, os padres congregados afirmam que a pobreza e a exclusão social têm forte conexão com a degradação ambiental. Não são crises independentes, mas sim uma única crise que é "sintoma de algo muito mais profundo: o modo equivocado como nossas sociedades e nossas economias estão organizadas" ${ }^{139}$, que é fonte geradora de descarte de recursos naturais e também de seres humanos. E citando novamente o papa, os padres congregados afirmam que a mentalidade de desenvolvimento deve ser substituída pela de sustentabilidade.

Neste contexto, o Decreto 1 convoca os jesuítas a ajudarem na cura de um mundo ferido através de uma nova forma de produção e de consumo que coloque a criação no centro. Entre as possibilidades de ação, propõe a missão junto as mais vulneráveis, o apoio ao compromisso com a Amazônia e a Bacia do Rio Congo, na África Central, reservas ambientais essenciais para o futuro da humanidade, e uma postura crítica e questionadora frente às questões econômicas. Essa Congregação também conclama teólogos, filósofos e outros intelectuais da Companhia a contribuírem para uma análise rigorosa das raízes do problema e possibilidades de solução para a crise.

138 Cf. Congregação Geral XXXVI, Dec. 1, n.25-28, p.47-48.

139 Congregação Geral XXXVI, Dec. 1, n.29, p.49. 
Finalmente, convida a todos a celebrar a criação, dando graça por "tanto bem recebido" $" 140$.

O documento enfatiza ainda que os jesuítas devem procurar construir pontes para promover a paz e dar razão à esperança de uma reconciliação mundial. Com Cristo, são chamados a se manterem perto da humanidade crucificada, contribuindo para criar uma família humana através da luta pela justiça. Lembra que os que estão longe da pobreza também precisam de uma mensagem de esperança e reconciliação para poderem se liberar do medo do diferente, entre eles os excluídos, os migrantes e os refugiados, e assim se abrirem à hospitalidade e à paz para com os inimigos. ${ }^{141}$

\section{3}

\section{Considerações finais do $2^{\circ}$ capítulo}

Desde a fundação, a Companhia de Jesus se compreendeu a partir do caráter apostólico. Sua missão era a salvação das almas, servindo Deus no mundo.

A partir do Concílio Vaticano II, a Companhia vem percebendo que para servir Deus no mundo, fazendo chegar às pessoas a mensagem do Reino, é necessário levar em consideração as contingências históricas de cada momento.

Esta foi a preocupação das últimas sete Congregações Gerais, que, com exceção da $32^{\mathrm{a}}$ e da $34^{\mathrm{a}}$, também se reuniram para eleger o Superior Geral. Em cada uma delas, os padres congregados se questionaram acerca das necessidades de sua época e a que fronteiras de missão os jesuítas deveriam prioritariamente direcionar seus esforços.

A $31^{\circ} \mathrm{CG}$, ainda sobre a influência direta do Concílio Vaticano II, que acontecia ao mesmo tempo, priorizou uma reflexão acerca dos novos tempos e das consequências do Concílio para a vida da Igreja, assim como um trabalho de adequação da legislação da Companhia para estes fins. Apesar de terem sido elencadas várias fronteiras de missão, houve uma ênfase na missão na fronteira do ateísmo e do ecumenismo.

A $32^{\mathrm{a}} \mathrm{CG}$ tratou de diversos assuntos ligados à vida religiosa dos jesuítas e de seu apostolado, mas enfatizou a fronteira da missão da fé e da promoção da justiça, no seu Decreto 4 intitulado “A nossa missão nos dias de hoje: Diaconia da

140 Exercícios Espirituais, n. 233. Apud Congregação Geral XXXVI, Dec. 1, n.30, p.50.

141 Cf. Congregação Geral XXXVI, Dec. 1, n.31, p.50. 
fé e promoção da justiça". Este documento foi emblemático, apesar de ter gerado muita controvérsia dentro da Companhia, e sua influência perpassa todos os decretos das congregações que a sucederam até os dias de hoje.

A $33^{\mathrm{a}} \mathrm{CG}$, aconteceu em um momento delicado da história da Companhia e foi convocada prioritariamente para eleger o sucessor de Pedro Arrupe, afastado por um problema de saúde. Essa congregação também continuou a centralizar a missão na fronteira da fé e da justiça, mas procurou corrigir erros de interpretação em relação ao Decreto 4 da $32^{\mathrm{a}} \mathrm{CG}$.

A $34^{a} \mathrm{CG}$, em continuidade com as duas anteriores, continuou a enfatizar a missão na fronteira da fé e da justiça, mas alargou o conceito de justiça, apresentando-a em três dimensões: a social, a cultural e a do diálogo interreligioso. Tratou, pela primeira vez, da questão ambiental como outra dimensão da justiça.

A $35^{\mathrm{a}} \mathrm{CG}$, dando seguimento às anteriores, retomou e aprofundou a questão ambiental como dimensão da justiça, em um momento em que os problemas de injustiça, exploração e destruição do meio ambiente tomavam proporções planetárias. Essa congregação fala, também pela primeira vez, do tema da reconciliação como uma tríplice resposta aos problemas do seu momento histórico: a reconciliação com Deus, a reconciliação entre os homens e a reconciliação com a natureza.

Por último, a recente $36^{\mathrm{a}}$ Congregação retoma a anterior, trabalhando mais detalhadamente as três dimensões da reconciliação citadas. Essa Congregação também aborda a inseparabilidade entre as problemáticas social e ecológica, tratando-a como uma única problemática socioambiental.

Os documentos das Congregações Gerais nos permitem perceber a preocupação da Companhia de Jesus em discernir os sinais dos tempos em cada momento histórico, determinando as fronteiras de missão a que é chamada a atuar em um mundo em constante mudança, buscando sempre responder da melhor forma aos apelos de Deus.

É justamente dentro deste espírito da Companhia de Jesus de renovação constante e compromisso no seguimento de Jesus Cristo, que Jorge Bergoglio, o papa Francisco, jesuíta, foi formado e desenvolveu sua espiritualidade, podendo surgir agora, neste momento conturbado da história do mundo e da Igreja, como esperança de uma profunda renovação eclesial. 


\section{3 \\ Francisco, o primeiro papa jesuíta da história da Igreja, sua eclesiologia e seu comprometimento com a missão nas fronteiras}

\section{1}

\section{A pós-modernidade e a eleição de Francisco}

$\mathrm{O}$ atual contexto em que vivemos, interpretado de diversas formas, tais como pós-modernidade, modernidade tardia, hipermodernidade ou sociedade pósindustrial (Alain Touraine ${ }^{142}$ e Daniel Bell ${ }^{143}$ ), pós-história ou fim da história (Francis Fukuyam ${ }^{144}$ ), pós-racionalidade ou idade pós-liberal (George Lindbeck $^{145}$ ), idade pós-metafísica (Jurgen Habernas ${ }^{146}$ ) ou pós-cristianismo (Émile Poulat ${ }^{147}$ Gabriel Vahanian ${ }^{148}$ ), não é somente uma época de mudanças. ${ }^{149}$ O que agora se vê acontecendo na sociedade ocidental é uma mudança de época que está deixando marcas profundas na vida do ser humano, em sua configuração e na sociedade ${ }^{150}$. Com a ausência de um nome comum, é usado o prefixo "pós" como marca do fim de uma era ou conceito.

Em função disto, o mundo está passando por uma série de transformações socioculturais geradas por diversas causas, cujos efeitos se fazem sentir na vida cotidiana das pessoas que é marcada por tensão, excesso de tarefas, instabilidade e insegurança. Esta nova realidade obriga a sociedade a rever tradições e valores herdados do passado que não mais respondem aos desafios que se apresentam atualmente à humanidade. Para se reencontrar com seu presente, o ser humano precisa abrir mão de um passado idealizado porque é na configuração atual da sociedade, com suas luzes e sombras, que ele é instado a viver. ${ }^{151}$

No entanto, esta crise da modernidade não afeta somente a sociedade secular, tendo também impacto sobre o religioso e, consequentemente, sobre a

\footnotetext{
142 Sociólogo francês.

143 Sociólogo americano.

144 Filósofo e economista político americano.

145 Teólogo luterano americano.

146 Filósofo e sociólogo alemão.

147 Teólogo francês.

148 Teólogo protestante francês.

149 Cf.DE MORI G.L. Disponível em: http://www.ihu.unisinos.br/images/stories/cadernos/teopublica/ 011 cadernosteologiapublica.pdf. Acesso em: 12 nov 2017.

150 Cf. BINGEMER, O Mistério e o Mundo, p.11.

151 Cf. MIRANDA, A reforma de Francisco: fundamentos teológicos, p.174.
} 
Igreja ${ }^{152}$. De acordo com Agenor Briguenti, "a crise da instituição eclesial e a crise da sociedade se entrelaçam, se reclamam, se desafiam, se complexificam, se esclarecem e se remetem mutuamente". 153

$\mathrm{Na}$ visão de Mario de França Miranda, SJ, o desafio do homem contemporâneo de viver como membro do atual contexto social é também o desafio de cada cristão imerso no mesmo contexto. No entanto, o cristão, ainda que como membro desta sociedade moderna, é convidado a pautar sua conduta no mundo em constante transformação pela mensagem evangélica, com a consciência de sua pertença à Igreja, que, por sua vez, tem como função iluminar e orientar cada um de seus membros neste processo de atualização da adesão a Jesus Cristo. $^{154}$

Mas, a Igreja, enquanto instituição eclesial, precisa estar consciente de que, na medida em que é parte desta sociedade em crise, é igualmente desafiada pelas mudanças e precisa responder a estes desafios, já que esta é a única maneira de se fazer entendida e acatada pelos seus membros e se tornar significativa e pertinente para a própria sociedade atual. ${ }^{155}$

$\mathrm{Na}$ visão de Briguenti, é neste contexto que se situa a importância do Concílio Vaticano II, quando este assume a crise e busca dialogar com a sociedade num esforço de atualização da Igreja, a partir de um aggiornamento de sua autocompreensão e de sua forma de presença no mundo, para superar, pelo menos em tese registrada em seus documentos, o longo e esclerosado modelo da cristandade. Entretanto, segundo este autor, apesar da Igreja ter assumido a crise e tentado superá-la, após o Vaticano II, enquanto instituição, ela fez pouco para isso, deixando assim a renovação do Concílio a meio caminho. Com certeza, houve, por parte de determinados segmentos da Igreja, enormes esforços de concretizar esta renovação e oferecer ao mundo uma nova presença cristã profética e transformadora, mas estes esforços esbarraram em velhas estruturas obsoletas e não conseguiram surtir os efeitos desejados. ${ }^{156}$

Para França Miranda, embora seja esperado que haja uma certa turbulência nos períodos pós-conciliares, os segmentos da Igreja ainda presos ao modelo de 152 Cf. BRIGUENTI, Uma instituição em crise e uma sociedade em crise. In: PASSOS e SOARES, Francisco: renasce a esperança, p.32.

${ }^{153}$ BRIGUENTI, Uma instituição em Crise e uma sociedade em crise. In: PASSOS e SOARES, Francisco: renasce a esperança, p.34.

${ }^{154} \mathrm{Cf}$. MIRANDA, A reforma de Francisco: fundamentos teológicos, p.174.

155 Cf. ibidem, loc. cit.

156 BRIGUENTI, A. op. cit, p.35-6. 
cristandade conseguiram impor, nas décadas que se seguiram ao Vaticano II, uma centralização exagerada no governo da Igreja, um controle severo da reflexão teológica e uma sucessão de pronunciamentos doutrinais do Magistério eclesiástico, contendo assim o processo de renovação iniciado pelo Concílio. Ao longo deste tempo, esta centralização e controle foram criando um clima de insatisfação entre os católicos que não se sentiam mais acolhidos pela Igreja em seus problemas e questionamentos. Como consequência desta insatisfação, muitos se afastaram da vida eclesial e, entre os que ficaram, outros tantos adotaram uma postura de não obediência silenciosa às prescrições do Vaticano, principalmente no que tange às questões morais. ${ }^{157}$

Foi sobre este pano de fundo que ocorreram os fatos que resultaram na eleição do papa Francisco. De acordo com Carlos Palacio esta eleição é o gestoresposta de Deus à situação de prostração, abandono e desamparo da Igreja nesse momento histórico. E é uma resposta que surpreendeu a todos. ${ }^{158}$ As surpresas começaram com a inesperada renúncia de Bento XVI, anunciada no dia 11 de fevereiro de 2013 e efetivada no dia 28 do mesmo mês. Esta renúncia desencadeou uma série de episódios que culminaram na inesperada eleição do cardeal argentino Jorge Mario Bergoglio como papa Francisco, que, segundo Dom Demetrio Valentini, sob a "auréola positiva do novo nome escolhido (...) foi logo sinalizando, com gestos e palavras, uma série de posturas, valores e opções pastorais que suscitaram uma grande esperança de retomada da renovação eclesial". 159

O pontificado de Francisco veio à tona como consciência da crise e como superação do mal-estar. ${ }^{160}$ Desde seus primeiros gestos e atos, que têm se repetido desde a sua eleição, o papa fez renascer a esperança de que esteja se iniciando um capítulo na história do governo da Igreja ${ }^{161}$ que possa impulsionar um novo ardor missionário na instituição e entre os católicos em geral. O comportamento do atual Bispo de Roma, que rompe com os padrões institucionais do papado,

\footnotetext{
157 Cf. MIRANDA, A reforma de Francisco: fundamentos teológicos, p.175.

158 Cf. PALACIO, Homilia da missa de ação de graças e oração pelo papa Francisco. Itaici: revista de espiritualidade inaciana, n. 91, p.5.

159 VALENTINI, Prefácio. In: PASSOS e SOARES, Francisco: renasce a esperança, p.10.

160 Cf. PASSOS e SOARES, Francisco: renasce a esperança, p.23

161 Cf. GONZÁLEZ-QUEVEDO, O novo rosto da Igreja: papa Francisco, p.31.
} 
sinaliza para uma nova compreensão do papel do pontífice e para uma nova prática do seu ministério. ${ }^{162}$

Para França Miranda, a eleição do papa Francisco mudou o clima de insatisfação que havia se impregnado na Igreja nas últimas décadas. Com sua figura simples e humilde, sua fala direta e clara, seus gestos proféticos e seu programa de renovação eclesial, ele contagiou não só os católicos, mas grande parte do planeta. A partir dele, a Igreja tem se mostrado a todos de forma mais simpática, mais humana, mais confiável e com capacidade de novamente atrair os que estão afastados e insatisfeitos. ${ }^{163}$ A eleição de Francisco criou um leque de enorme de expectativas que pode justificar uma esperança real de retomada do impulso renovador desencadeado pelo Concílio Vaticano II há mais de cinquenta anos atrás. ${ }^{164}$

De acordo com Carlos Palacio, este modo de ser de Francisco só foi possível com a renúncia de Bento XVI, que devolveu à figura do papa os seus contornos humanos de um ser limitado, condicionado de muitas formas, fragilizado pela idade, capaz de alegrar-se e de sofrer como qualquer ser humano. Para este teólogo, quando há a exaltação mítica da função, existe o risco desta se sobrepor à pessoa do papa e anulá-la. E quando a pessoa desaparece por detrás da função, ela se torna insignificante em si mesma. A figura do papa tinha, até então, uma aura de sagrado, de deslumbramento, de fascínio, mas também de distância em relação aos problemas concretos e do cotidiano das pessoas. Em Francisco, porém, a pessoa aparece em primeiro plano, devolvendo vida e calor humano à função, e esta pode ser a razão pela qual os gestos do papa despertaram ânimo e esperança à maioria dos católicos ${ }^{165} \mathrm{e}$ admiração de tantos mais.

Em sua entrevista a Antônio Spadaro, SJ, diretor da revista Civiltà Cattolica, publicada pelos jesuítas, em Roma, o próprio Francisco deixa transparecer esta pessoa humana que se sobrepõe à função quando é solicitado a responder à questão “Quem é Jorge Bergoglio?”:

Não sei qual possa ser a definição mais correta. Eu sou um pecador. Esta é a definição mais correta. E não é um modo de dizer, um gênero literário. Sim, posso

\footnotetext{
162 Cf. PASSOS e SOARES, Francisco: renasce a esperança, p.18.

163 Cf. MIRANDA, A reforma de Francisco: fundamentos teológicos, p.175.

164 Cf. VALENTINI, D. Prefácio In: PASSOS e SOARES, Francisco: renasce a esperança, p.10.

165 Cf. PALACIO, Homilia da missa de ação de graças e oração pelo papa Francisco. Itaici: revista de espiritualidade inaciana, n.91, p.7.
} 
talvez dizer que sou um pouco astuto, sei mover-me, mas é verdade que sou também um pouco ingênuo. Sim, mas a síntese melhor, aquela que me vem mais de dentro e que sinto mais verdadeira, é exatamente está: "Sou um pecador para quem o Senhor olhou". Sou alguém que é olhado pelo Senhor. ${ }^{166}$

Na visão de Palacio, com este novo modo de ser o papa está acenando para o mundo que o caminho da Igreja não é a ostentação, a grandiosidade ou o poder e que a linguagem da Igreja tem que ser a linguagem simples da vida, como a de Jesus nas parábolas do evangelho. ${ }^{167}$ Isto ficou bem claro em suas palavras, por ocasião da celebração de abertura do seu pontificado:

\begin{abstract}
Hoje, nesta solenidade de São José, celebramos o início do ministério do novo bispo de Roma, sucessor de Pedro, que envolve também um poder. Mas que poder? Jamais esqueçamos de que o verdadeiro poder é o serviço e que o próprio papa, para exercer o poder, deve entrar sempre mais naquele serviço que tem o seu vértice luminoso na Cruz; deve olhar para o serviço humilde, concreto, rico de fé, de São José e, como ele, abrir os braços para guardar todo o Povo de Deus e acolher, com afeto e ternura, a humanidade inteira, especialmente os mais pobres, os mais fracos, os mais pequeninos, aqueles que Mateus descreve no juízo final: quem tem fome, sede, é estrangeiro, está nu, doente, na prisão. ${ }^{168}$
\end{abstract}

Para Dom Valentini, a surpresa que a eleição de Francisco trouxe ao mundo está também no fato de que, entre todos os cenários imaginados para o desfecho do conclave, não haviam apostas no cardeal de Buenos Aires. ${ }^{169}$ A rapidez da escolha de Bergoglio, eleito no segundo dia do conclave, mostra que houve, entre os 115 cardeais votantes encerrados na Capela Sistina ${ }^{170}$, um apoio amplo e imediato com a intenção de possibilitar ao novo papa a desenvoltura necessária para executar a missão que naquele momento lhe estava sendo confiada. Bergoglio foi eleito no quinto escrutínio, com mais de 90 votos, quando seriam necessários somente $77 .{ }^{171}$

Além disso, a surpresa desta escolha também provinha de diversas circunstâncias que se realizavam pela primeira vez na história da Igreja ${ }^{172}$ : ele é o primeiro papa jesuíta, contradizendo a tradição inaciana ${ }^{173}$, o primeiro papa do continente americano, sendo ainda o primeiro não-europeu escolhido para ser o

\footnotetext{
166 SPADARO, Entrevista exclusiva do papa Francisco, p.7-8.

${ }^{167}$ Cf. PALACIO, Homilia da missa de ação de graças e oração pelo papa Francisco. Itaici: revista de espiritualidade inaciana, n.91, p.7.

168 VASQUES, Coisas do papa Francisco: primeiro papa latino-americano, p.10.

${ }^{169}$ Cf. VALENTINI, Prefácio. In: PASSOS e SOARES, Francisco: renasce a esperança, p.10.

170 ALTEMAYER Jr., Os muitos partos do bispo de Roma. In: PASSOS e SOARES, Francisco: renasce a esperança, p.105.

171 Cf. GONZÁLEZ-QUEVEDO, O novo rosto da Igreja: papa Francisco, p.28.

172 Cf. VALENTINI, op. cit., loc. cit.

173 GONZÁLEZ-QUEVEDO, op. cit., p.29.
} 
novo bispo de Roma em mais de 1200 anos. ${ }^{174}$. Finalmente, ele também é o primeiro a assumir o nome Francisco.

\section{2 \\ Francisco, o papa jesuíta}

Jorge Mario Bergoglio nasceu em 17 de dezembro de 1936, em Buenos Aires, onde viveu quase toda a sua vida. ${ }^{175}$ Entrou muito jovem para a Companhia de Jesus e, de acordo com a teóloga Maria Clara Lucchetti Bingemer, recebeu uma formação que o configurou segundo o estilo único que os Exercícios Espirituais de Santo Inácio imprimem em quem faz a experiência. Segundo ela, as características mais marcantes do papa, tais como viver austeramente, usar transporte público, andar pelas periferias da cidade junto aos mais pobres, são um reflexo da formação que recebeu na Companhia. ${ }^{176}$

Durante a entrevista a Antonio Spadaro, quando respondia à questão por que havia se tornado jesuíta, o próprio Francisco respondeu:

Eu queria algo mais, mas não sabia o quê. Tinha entrado no seminário. Gostava dos dominicanos e tinha amigos dominicanos. Depois, porém, escolhi a Companhia, que conhecia bem, porque o seminário estava entregue aos jesuítas. Da Companhia impressionaram-me três coisas: o espírito missionário, a comunidade e a disciplina. Isto é curioso, porque eu sou um indisciplinado nato. Mas a sua disciplina, o modo de organizar o tempo, impressionaram-me muito. E, depois, há algo fundamental para mim: a comunidade. Havia buscado desde sempre uma comunidade. Não me via sacerdote sozinho: tenho necessidade de comunidade. ${ }^{177}$

Comentando esta entrevista, Spadaro, que é também jesuíta, disse que reencontrou nas palavras de Francisco sobre missão e comunidade todos os documentos da Companhia de Jesus que falam do tema. ${ }^{178}$

Bergoglio recebeu sua formação como jesuíta na Argentina e no Chile e ocupou todos os cargos importantes na Companhia de Jesus em seu país natal. Foi mestre de noviços, provincial e reitor do Colégio Máximo. Depois disso, foi indicado para o episcopado, se tornando bispo e, mais tarde, arcebispo de Buenos

\footnotetext{
174 ALTEMAYER Jr., OS muitos partos do bispo de Roma. In: PASSOS e SOARES, Francisco: renasce a esperança, p.105. ${ }^{175}$ GONZÁLEZ-QUEVEDO, O novo rosto da Igreja: papa Francisco, p.35.

176 Cf. BINGEMER, Esperança de futuro para a Igreja. In: PASSOS e SOARES, Francisco: renasce a esperança, p.242.

177 SPADARO, Entrevista exclusiva do papa Francisco, p.9.

178 Ibidem, loc. cit.
} 
Aires. ${ }^{179}$ Inicialmente recusou a indicação para o episcopado, mas, como os jesuítas estão ligados ao papa por voto de obediência especial, o convite só foi finalmente aceito por vontade expressa do Pontífice. ${ }^{180}$

Luis González-Quevedo, SJ, conta que, quando Bergoglio era arcebispo de Buenos Aires, foi-lhe oferecido o cargo de prefeito em um dicastério ${ }^{181}$ na Cúria Romana, mas ele o recusou por não querer morar em Roma. Apesar desse seu desejo, em 13 de março de 2013, ao ser eleito papa, seu destino foi selado ao da cidade. Mais do que isto, a partir deste momento, seu destino passou a se identificar com o da própria Igreja ${ }^{182}$.

Na visão de Maria Clara Bingemer, o fato do papa Francisco ser o primeiro jesuíta em toda a história da Igreja encontra sua raiz na própria Companhia de Jesus, fundada por Inácio de Loyola nos primeiros tempos da modernidade. Nesta época, a Igreja vivia um momento complicado que propiciou o surgimento da Reforma Protestante e Santo Inácio, diante dos acontecimentos que vivenciava, estava bem ciente do mal que as honras e o prestígio podiam causar à vida cristã. Por isso, já nas Constituições da Companhia de Jesus, deixa bem explícito que o jesuíta não deveria aceitar dignidades eclesiásticas. Esta renúncia, inclusive, tornou-se objeto de um dos votos da ordem que devem ser pronunciados pelos postulantes. ${ }^{183}$ As Constituições dizem o seguinte sobre o tema:

Farão também promessa a Deus Nosso Senhor de nunca procurar prelatura ou dignidade alguma fora da Companhia, e de recusar a escolha de sua pessoa para semelhante cargo, quando deles depender, a não ser constrangido pela obediência a quem pode mandar-lhes sob o pecado. Cada um há de esforçar-se por servir às almas segundo a nossa profissão, feita de humildade e abatimento, e por não privar a Companhia de homes que lhe são necessários para o seu fim $(. . .)^{184}$

A $34^{a}$ Congregação Geral também se posiciona em relação à questão:

\footnotetext{
179 Disponível em: http://agape.usuarios.rdc.puc-rio.br/amai/osegredodopapajesuita.pdf. Acesso em: 12 jan 2018.

180 Cf. GONZÁLEZ-QUEVEDO, Quo vadis. In: Convergência, dez 2017.

181 Dicastério (do grego: ठıкабтns, juiz) é o nome para os departamentos do governo da lgreja Católica que compõem a Cúria Romana. Entre os dicastérios estão: a Secretaria de Estado, as congregações, os tribunais eclesiásticos, conselhos, ofícios, comissões e comités. O papa delega a cada dicastério uma função do governo.

182 Cf GONZÁLEZ-QUEVẺDO, Quo vadis. In: Convergência, dez 2017.

183 BINGEMER, Esperança de futuro para a Igreja. In: PASSOS e SOARES, Francisco: renasce a esperança, p.241-2.

${ }_{184}$ Constituições da Companhia de Jesus e normas complementares, Décima Parte, n.817, § 6, p.224-5.
} 
Em total concordância com o carisma da Companhia e com seu desejo de ser disponível para a missão, a CG 34 reafirma com firmeza a tradição da Companhia de resistir a nomeações para o episcopado, enquanto isso possa compaginar-se com a obediência. Para Inácio, este princípio era essencial para a missão e o bom estado desta "mínima Companhia" e de modo algum contradizia seu ideal de disponibilidade para a missão. Os jesuítas deviam servir à Igreja e ao Sumo Pontífice, mas não como bispos (cf. Const. 617-618). A fim de esclarecer esse ponto, a CG 34 urge o Padre Geral para que prossiga o diálogo sobre esse tema com a Santa Sé e, se julgar oportuno, promulgue normas claras a serem seguidas por todo jesuíta que venha a ser informado que se pensa nele como candidato ao episcopado. ${ }^{185}$

Para a teóloga M. C. Bingemer, ao longo da história, houve algumas ocasiões em que este voto foi suplantado por uma necessidade eclesial imperiosa, por uma circunstância de urgência, ou mesmo por uma prioridade missionária inegável. Mas, apesar de ter havido momentos em que jesuítas tiveram necessidade de assumir posições de destaque, mesmo assim, nunca houve um papa jesuíta. Está no espírito da ordem não buscar - a não ser quando Deus mostre claramente sua vontade em sentido oposto - nem aceitar postos hierárquicos. ${ }^{186}$

De acordo com González-Quevedo, a escolha do nome Franciscus (Francisco, em latim) feita por Bergoglio é muito significativa, pois representa, ao mesmo tempo, uma ruptura e uma novidade nos nomes da sucessão dos bispos de Roma. Como o próprio papa esclareceu, ao fazê-lo, pensou em Francisco de Assis, um simples leigo, e em seu revolucionário ideal de pobreza, visando com isto colocar os pobres no centro das atenções. ${ }^{187}$ Ao escolher o nome do poverello de Assis ${ }^{188}$ deixou clara sua preocupação e comprometimento para com os pobres, a natureza e a paz. Para Leonardo Boff, "Francisco não é um nome. É um projeto de Igreja pobre, simples, evangélica e destituída de todo poder" ${ }^{189}$.

Carlos Palacio lembrou, na homilia que fez no domingo seguinte à eleição de Francisco, que o nome escolhido era uma referência ao evangelho sem glosa: o homem dos pobres, o homem da paz, o amante da criação. Para ele, é possível que ao escolher este nome, Bergoglio, como jesuíta, se tenha lembrado que a referência a Francisco de Assis esteve presente e teve um forte impacto no início

185 Cf. Decretos da Congregação Geral XXXIV, Dec. 6, Jesuíta presbítero: sacerdácio ministerial e identidade jesuítica, n.31. Recomendação ao Padre Geral, p.138.

186 BINGEMER, Esperança de futuro para a Igreja. In: PASSOS e SOARES, Francisco: renasce a esperança, p.242.

187 Cf. SOUZA e RIBEIRO, Obstáculos e possibilidades para criar um clima de reformas. In: PASSOS e SOARES, Francisco: renasce a esperança, p.179-80.

188 Povorello significa dotado de pouco ou nenhum recurso material. Francisco de Assis também ficou conhecido como "Il Povorello" de Assis por seu despojamento total dos bens e recursos materiais, apesar de sua origem nobre.

189 Cf. GONZÁLEZ-QUEVEDO, Quo vadis. In: Convergência, dez 2017. 
do processo de conversão de Santo Inácio ${ }^{190}$, como se pode notar em um trecho de sua autobiografia:

"Contudo, Nosso Senhor o socorria, fazendo suceder a esses pensamentos outros que nasciam de suas leituras, porque lendo a vida dos Santos, detinha-se a pensar, raciocinando consigo mesmo: e se eu fizesse como São Francisco? Ou isto que São Domingos realizou? Assim discorria por muitos que achava bons, propondo-se empreendimentos difíceis e grandiosos. Quando percebia esses propósitos, parecia encontrar em si facilidade para pô-los em prática. Mas todo o seu discorrer era falar consigo: São Francisco praticou isto, eu tenho de fazer também!"191

Na opinião de M. C. Bingemer, no entanto, não se pode deixar de pensar que, sendo Francisco um jesuíta, é possível que, por trás do nome escolhido pelo novo pontífice, também exista um outro Francisco, além do de Assis. Este seria Francisco Xavier, um dos companheiros de Inácio de Loyola que ainda bem jovem foi mandado em missão ao Oriente. ${ }^{192}$ Xavier levou a fé católica à Índia, depois ao Japão, e tinha a intenção de também entrar na China, o enorme e isolado Império do Meio. Não teve êxito nesta última missão porque morreu praticamente sozinho, aos 46 anos, às portas da China ${ }^{193}$, mas mesmo assim, não muito tempo após sua morte, sua fama de santidade já havia se espalhado pelo mundo e, hoje, é considerado pela Igreja como um dos padroeiros das missões. ${ }^{194}$

O cientista político Luiz Alberto Gómez de Souza conta que Francisco Xavier e outros jesuítas que o sucederam na missão no Oriente quiseram repensar o estilo e a liturgia romana nessas novas realidades, mas o míope provincianismo europeu da Cúria Romana daquele tempo não o permitiu. ${ }^{195} \mathrm{Na}$ visão de Bingemer, o missionário Xavier, juntamente com o povorello de Assis, estão bastante presentes no novo papa. ${ }^{196}$ Para Souza, na trilha de Xavier, o papa Francisco tem trabalhado na dimensão de uma Igreja da diversidade, em tempos planetários e ao mesmo tempo pluralistas. ${ }^{197}$

González-Quevedo defende que a escolha do nome por parte de um papa não é acaso nem questão de gosto e sim o reflexo do projeto desse pontífice, um

190 Cf. PALACIO, Homilia da missa de ação de graças e oração pelo papa Francisco. Itaici: revista de espiritualidade inaciana, n.91, p.7-8.

191 SANTO INACIO, O relato do Peregrino, p.30-1.

192 Cf. BINGEMER, Esperança de futuro para a Igreja. In: PASSOS e SOARES, Francisco: renasce a esperança, p.242.

193 Cf. SOUZA e RIBEIRO, Obstáculos e possibilidades para criar um clima de reformas. In: PASSOS e SOARES, Francisco: renasce a esperança, p.179.

194 Cf. BINGEMER, op. cit., p.243.

195 Cf. SOUZA e RIBEIRO, op. cit. loc. cit.

196 BINGEMER, op. cit., loc. cit.

197 Cf. SOUZA e RIBEIRO, op. cit., p.179-80. 
sinal ao mundo das linhas teológicas, atitudes pastorais e políticas de governo que irão marcar o pontificado. De acordo com este teólogo, em 1978, quando o cardeal Alberto Luciani escolheu o nome de João Paulo I para homenagear seus dois antecessores, João XXIII e Paulo VI, ele deixava patente a intenção de aplicar, durante seu pontificado, os decretos do Concílio Vaticano II, em continuação à obra dos dois papas que o haviam respectivamente inaugurado $\mathrm{e}$ finalizado. Com sua morte prematura, o cardeal Karol Wojtyla escolheu o nome de João Paulo II como afirmação de que assumia a tarefa do antecessor. ${ }^{198}$

A escolha do nome Francisco foi acompanhada de outros pequenos gestos, coerentes com o nome escolhido e que mostram o rosto que Bergoglio pretende dar a seu pontificado. Quando apareceu no balcão da basílica de São Pedro, pela primeira vez, logo após ter sido escolhido e já vestindo as vestes pontifícias simplificadas, o novo papa se apresentou como "bispo de Roma", se colocando como mais um entre os demais bispos. Estava demonstrando, assim, sua intenção de valorizar a prática do "colegiado episcopal"199 onde cada bispo está vinculado a uma "Igreja particular", sendo a Igreja no mundo o resultado da comunhão de Igrejas locais, de onde emerge a importância especial da "Igreja de Roma", como símbolo da comunhão fraterna entre todas as Igrejas. ${ }^{200}$

Depois desta apresentação, Francisco rezou pelo seu antecessor Bento XVI e, antes de dar a benção Urbi et Orbi ao povo, pediu que o abençoassem a ele próprio. Esta postura deixa transparecer uma visão de Igreja impregnada dos sentimentos do Concílio, que falam da Igreja como "Povo de Deus", onde todos são corresponsáveis pela missão ${ }^{201}$ e a quem o sucessor de Pedro serve como sinal de unidade e como pastor que cuida das ovelhas. ${ }^{202}$ Após a bênção, se despediu da multidão de forma coloquial, usando as expressões ci vediamo presto, buona notte e buon riposo. ${ }^{203}$ Ali, naquela primeira aparição, com os primeiros gestos do novo papa, já se podia pressentir a chegada de um novo tempo pascal para a Igreja ${ }^{204}$, nas bases propostas pelo Vaticano II. Sobre esta aparição e sobre a forma como

\footnotetext{
198 Cf. BINGEMER, Esperança de futuro para a Igreja. In: PASSOS e SOARES, Francisco: renasce a esperança, p.241.

${ }^{199} \mathrm{Cf}$. GONZÁLEZ-QUEVEDO, Quo vadis. In: Convergência, dez 2017.

200 Cf. VALENTINI, Prefácio. In: PASSOS e SOARES, Francisco: renasce a esperança, p.12.

201 Cf. Ibidem, p.12.

202 Cf. PASSOS e SOARES, Francisco: renasce a esperança, p.18.

203 Cf. GONZÁLEZ-QUEVEDO, Quo vadis. In: Convergência, dez 2017.

204 Cf. BINGEMER, Esperança de futuro para a Igreja. In: PASSOS e SOARES, Francisco: renasce a esperança, p.238.
} 
ele se despediu da multidão, John O’ Malley, SJ, conta que Francisco, em sua opinião, agiu como ele esperaria que um jesuíta fizesse ${ }^{205}$.

González-Quevedo relata que estes gestos, que na primeira noite já deixavam perceber a personalidade do papa recém-eleito, continuaram a se repetir pelos dias que se seguiram: ele pagou as despesas feitas na casa onde se hospedara, recusou o carro destinado ao pontífice, utilizando o mesmo ônibus dos cardeais e, ainda, continuou a usar a mesma cruz peitoral que usava em Buenos Aires e os sapatos pretos comuns, ao invés dos vermelhos normalmente usados pelos papas. Poucos dias após a eleição, anunciou que moraria na Casa Santa Marta e não nos aposentos pontifícios, como era de se esperar. Desde então, esta postura de simplicidade vem marcando o pontificado de Francisco. ${ }^{206}$

$\mathrm{Na}$ visão de França Miranda, quando Jorge Mario Bergoglio recupera a dimensão profética do cristianismo, quando prega uma conversão de todos ao Evangelho dentro de sua simplicidade exigente, quando procura desfazer mentalidades e estruturas de poder incrustadas no corpo eclesial, quando demonstra uma enorme sensibilidade pelos mais pobres e sofridos e quando abre debates que atingem em cheio a vida da Igreja, é possível se perceber, nessas atitudes os efeitos da formação espiritual recebida na Companhia de Jesus ${ }^{207}$ e seu compromisso com a missão sempre renovado e atualizado nas Congregações Gerais.

De acordo com J. O’ Malley, esta formação jesuítica de Francisco se fez sentir de maneira forte, logo nos primeiros dias de seu pontificado, quando ele se definiu como um pecador. ${ }^{208}$ Esta definição é a que inicia o primeiro decreto substantivo da 32ª Congregação Geral da Companhia de Jesus e diz: "O que vem a ser um jesuíta? É saber que, embora pecador, se é chamado a ser companheiro de Jesus como o foi Santo Inácio."209 O então padre Bergoglio estava presente nesta congregação e votou pela aprovação do decreto. ${ }^{210} \mathrm{Na}$ visão de Elias Royon,

\footnotetext{
205 Disponível em: http://www.ihu.unisinos.br/539064-papa-francisco-jesuíta-e-então. Acesso em: 12 nov 2017.

206 Cf. GONZÁLEZ-QUEVEDO, Quo vadis. In: Convergência, dez 2017.

207 Cf. MIRANDA, A reforma de Francisco: fundamentos teológicos, p.175.

208 Disponível em: http://www.ihu.unisinos.br/539064-papa-francisco-jesuíta-e-então. Acesso em: 12 nov 2017.

209 Decretos da Congregação Geral XXXII. Declaração: O Jesuíta Hoje. n.11, § 1, p.22.

210 Disponível em: http://www.ihu.unisinos.br/539064-papa-francisco-jesuíta-e-então. Acesso em: 12 nov 2017.
} 
SJ, estas palavras certamente ainda ressoam no seu coração, definindo-o como jesuíta. $^{211}$

Em julho de 2013, já como papa, no voo de regresso a Roma por ocasião da vinda ao Brasil para a XXVII Jornada Mundial da Juventude, quando perguntado por uma jornalista se se sentia jesuíta, o papa Francisco prontamente respondeu, reafirmando sua formação e espiritualidade:

Eu sinto-me jesuíta na minha espiritualidade; na espiritualidade dos Exercícios, aquela que eu tenho no coração. E tanto me sinto assim que, dentro de três dias, irei celebrar com os jesuítas a festa de Santo Inácio (...). Eu não mudei de espiritualidade, não. Francisco, sim; franciscano, não. Sinto-me jesuíta e penso como jesuíta. Não hipocritamente, mas penso como jesuíta. ${ }^{212}$

A formação que Bergoglio recebeu na escola de Santo Inácio de Loyola é decisiva e, de acordo com França Miranda, está refletida na eclesiologia e no sentido de missão do papa Francisco. Tanto as experiências comunitárias, espirituais e intelectuais que teve como seminarista na ordem dos jesuítas, quanto suas atividades exercidas já como jesuíta, tanto na área da espiritualidade como na de governo, sempre se realizaram dentro do espírito e das orientações da Companhia de Jesus e de suas Congregações. Para o teólogo, a partir de suas experiências de vida, o ser humano, de forma consciente ou não, assimila valores, critérios, tradições, hábitos, padrões de comportamento que marcam sua personalidade e que definem o modo de olhar a realidade, emitir juízos, estabelecer objetivos. São estas características que, em última análise constituem a própria identidade do indivíduo e isto também vale para Jorge Bergoglio. ${ }^{213}$

\section{3}

\section{A herança inaciana na eclesiologia de Francisco}

Mario de França Miranda, em seu artigo "Francisco: papa e jesuíta", publicado no livro Francisco: renasce a esperança, organizado por João Décio Passo e Afonso Maria Ligorio Soares, elenca cinco características da eclesiologia de Francisco que tem em sua raiz a espiritualidade de Santo Inácio de Loyola e a

\footnotetext{
211 Disponível em: http://www.ihu.unisinos.br/78-noticias/560975-o-que-o-papa-francisco-ja-disseaos-jesuitas-artigo-de-elias-royon Acesso em: 12 nov 2017.

212 Disponível em: http://w2.vatican.va/content/francesco/pt/travels/2013/outsude/documents/papafrancesco-gmg-rio-de-janeiro-3013.html. Acesso em: 12 nov 2017.

${ }^{213}$ Cf. MIRANDA, Francisco: papa e jesuíta. In: PASSOS e SOARES, Francisco: renasce a esperança, p.134-5.
} 
missão nas fronteiras, seguindo as definições das últimas congregações dos jesuítas. São elas: uma Igreja missionária, uma Igreja que escuta a sociedade, uma Igreja que promove a liberdade cristã, uma Igreja voltada para os pobres e uma Igreja que vive sua fé. Todas estas características têm base nos decretos da últimas Congregações Gerais, assim como nos demais documentos da Companhia de Jesus.

\subsection{1}

\section{Uma Igreja missionária}

De acordo com França Miranda, o sentido da Companhia de Jesus é estar a serviço da Igreja em vista da missão. Cada jesuíta é chamado por Deus para ser enviado em missão, qualquer que ela seja e seja onde for, e deve administrar toda a sua vida em vista da missão, como membro de um corpo apostólico. Em função disto, desde o início, Inácio de Loyola teve a preocupação de prescrever aos membros da ordem uma sólida formação espiritual e uma ampla e profunda formação intelectual que, juntas, os preparassem para enfrentar os desafios encontrados no exercício de qualquer missão que lhes fosse confiada. ${ }^{214}$

No Proêmio da Quarta Parte das Constituições da Companhia, intitulada Como Instruir nas Letras e em outros meios de ajudar o próximo os que permanecem na Companhia, já é possível perceber esta preocupação com a formação dos seus membros para a missão:

O que a Companhia tem diretamente em vista é ajudar as almas próprias e as do próximo a atingir o fim último para o qual foram criadas. Este fim exige uma vida exemplar, doutrina necessária, e maneira de a apresentar. Portanto, uma vez que se reconhecer nos candidatos o requerido fundamento de abnegação de si mesmos e o seu necessário progresso na virtude, devem-se procurar os graus de instrução e o modo de utilizá-la para ajudar a melhor conhecer e servir a Deus nosso Criador e Senhor. ${ }^{215}$

Nas Notas Complementares da revisão renovada e atualizada das Constituições da Companhia de Jesus, feita à luz do Concílio Vaticano II, a mesma preocupação se faz sentir:

214 Cf. MIRANDA, Francisco: papa e jesuíta. In: PASSOS e SOARES, Francisco: renasce a esperança, p.135-6.

${ }^{215}$ Constituições da Companhia de Jesus. II-B: Constituições com suas Declarações. Proêmio da Quarta Parte. n.307, § 1, p.115. 
Os estudos especiais, entendidos à luz de sua finalidade apostólica, sejam fortemente incentivados pelos Superiores. Os que se dedicam a eles principalmente em universidades civis, sejam ajudados a perceber a sua conexão com a filosofia e com a teologia e a realizar pessoalmente esta integração. Procure-se que tenham um bom acompanhamento espiritual e que participem efetivamente da vida de alguma comunidade da Companhia. Promova-se a formação no campo literário, artístico e científico, inclusive nas ciências sociais, para um melhor conhecimento e análise da realidade, também no campo da história e nos diversos aspectos da cultura da região onde se exercerá o apostolado, bem como nos meios modernos de comunicação social." 216

$\mathrm{Na}$ mesma linha dos documentos anteriores, a $35^{\mathrm{a}}$ Congregação Geral diz o seguinte sobre o tema:

Demasiadas vezes estamos isolados do contato real com a não crença, e com as consequências concretas e quotidianas da injustiça e da opressão. Arriscamo-nos a não chegar a ouvir a interpelação evangélica que nos é dirigida pelos homens e mulheres do nosso tempo. Uma inserção mais resoluta no mundo será, portanto, testemunho decisivo da nossa fé, da nossa esperança e da nossa caridade apostólica. Com discernimento e baseando-nos em comunidades apostólicas vivas, estaremos nós dispostos a ser testemunhas do Evangelho em situações difíceis, nas quais a nossa fé e a nossa esperança serão postas à prova da incredulidade e da injustiça? Estaremos dispostos, por outro lado, a consagrar-nos aos estudos austeros e profundos que cada vez mais se requerem para compreender e resolver os problemas contemporâneos, em teologia, em filosofia e nas ciências humanas? Essa inserção é necessária se queremos partilhar a nossa fé e a nossa esperança, e deste modo anunciar o Evangelho que realmente corresponda à expectativa e às aspirações dos nossos contemporâneos. ${ }^{217}$

Esta característica da formação dos jesuítas para missão será responsável por levá-los a diversas frentes de ação, que podem ser tanto de cunho educacional, missionário, intelectual, assistencial ou social, dando-lhes condições de enfrentamento de qualquer situação que porventura venham a se deparar. ${ }^{218}$

A centralidade da missão na espiritualidade inaciana é facilmente percebida na eclesiologia do papa Francisco. Já no início da Exortação Apostólica Evangelli Gaudium, publicada ainda no primeiro ano de seu pontificado, ele convoca todos os cristãos ${ }^{219}$ à missão com as seguintes palavras:

A Evangelização obedece ao mandato missionário de Jesus; "Ide, pois, fazei discípulos de todos os povos, batizando-os em nome do Pai, do Filho e do Espírito

\footnotetext{
216 Constituições da Companhia de Jesus. Normas Complementares. Capítulo IV: Sobre a formação intelectual n.94-95, §2, p.265.

217 Congregação Geral XXXII, Decreto 4, § 84, n.35, p.51.

218 Cf. MIRANDA, Francisco: papa e jesuíta. In: PASSOS e SOARES, Francisco: renasce a esperança, p.135-6.

219 Cf. MIRANDA, Francisco: papa e jesuíta. In: PASSOS e SOARES, Francisco: renasce a esperança, p.136.
} 
Santo, ensinando-os a cumprir tudo quanto vos tenho mandado" Mt 28, 19-20. (EG n.19)

Mais adiante, completa:

Na Palavra de Deus, aparece constantemente este dinamismo de "saída", que Deus quer provocar nos crentes. (...). Naquele "ide!" de Jesus estão presentes os cenários e desafios sempre novos na missão evangelizadora da Igreja, e hoje todos somos chamados a esta nova "saída" missionária. Cada cristão e cada comunidade há de discernir qual é o caminho que o Senhor lhe pede, mas todos somos convidados a aceitar este chamado: sair da própria comodidade e ter a coragem de alcançar todas as periferias que precisam do Evangelho. ( $E G$ n.20)

Para França Miranda, a Igreja, na visão de Francisco, é uma Igreja que, na linha da Constituição Apostólica Gaudium et Spes, está a serviço da humanidade para levar-lhe os valores evangélicos de amor fraterno, justiça, solidariedade e perdão. É uma Igreja em diálogo com o mundo, voltada para aos anseios e perplexidades da sociedade, capaz de captar os sinais dos tempos e com a consciência da ação do Espírito Santo sobre ela própria. Como consequência disto, o atual papa defende uma Igreja que seja sensível ao clamor de uma sociedade em crise que busca referências substantivas para além das fornecidas pela atual cultura pós-moderna, fundamentalmente individualista e consumista. ${ }^{220}$

O grande risco do mundo atual, com sua múltipla e avassaladora oferta de consumo, é uma tristeza individualista que brota do coração comodista e mesquinho, da busca desordenada de prazeres superficiais, da consciência isolada. Quando a vida interior se fecha nos próprios interesses, deixa de haver espaço para os outros, já não entram os pobres, já não se ouve a voz de Deus, já não se goza da doce alegria do seu amor, nem fervilha o entusiasmo de fazer o bem. Este é um risco, certo e permanente, que correm também os crentes. Muitos caem nele, transformando-se em pessoas ressentidas, queixosas, sem vida. Esta não é a escolha duma vida digna e plena, este não é o desígnio que Deus tem para nós, esta não é a vida no Espírito que jorra do coração de Cristo ressuscitado. ${ }^{221}$

Eduardo Hoornaert, um dos fundadores da CEHILA ${ }^{222}$, em seu artigo "O que significa uma 'Igreja em saída' segundo o papa Francisco", conta que dias antes de ser eleito, em 9 de março de 2013, em uma intervenção que fez em uma das sessões da Congregação dos Cardeais que antecederam o conclave e a eleição do novo papa, o então cardeal de Buenos Aires já deixava transparecer em sua fala

\footnotetext{
220 Cf. Ibidem, loc. cit.

221 Disponível em: http://w2.vatican.va/content/francesco/pt/apost_exhortations/documents/papafrancesco_esortazione-ap_20131124_evangelii-gaudium.html. Acesso em: 27 jan 2017. ${ }_{222}$ Comisión para el Estudio de la Historia de las Iglesias em America Latina y el Caribe
} 
o prenúncio da expressão "Igreja em saída" tão atual nos dias de hoje $\mathrm{e}^{223}$. Foi o próprio papa Francisco, depois de eleito, que revelou em uma carta ao então cardeal de Havana, Dom Jaime Ortega, os termos desta sua intervenção no préconclave.

Desta carta, Dom Ortega recolheu quatro pontos que deixam perceber com clareza a visão pessoal de Francisco sobre a igreja do tempo presente. O primeiro destes pontos dizia respeito à evangelização e expressava que "a Igreja deve sair de si mesma e ir às periferias" não apenas geográficas, mas também existenciais, que se manifestam no mistério do pecado, da dor da injustiça e da ignorância, entre outras. O segundo ponto marcava uma crítica à Igreja "autorreferencial”, que olha a si mesma em uma espécie de "narcisismo teológico" que a afasta do mundo e "quer Jesus Cristo dentro de si e não o deixa sair".

Em consequência disso, Dom Ortega apontou para um terceiro ponto que considerou relevante na intervenção de Bergoglio. Segundo ele, existem, para Francisco, duas imagens de Igreja: uma "Igreja evangelizadora que sai de si" e a outra, uma "Igreja mundana que vive em si, de si, e para si”. E é esta consideração dual de Igreja, em sua visão, que serve de ponto de partida para as mudanças e reformas que o papa tenta fazer na Igreja.

O quarto e último ponto sublinhado por Ortega tem a ver com a expectativa de Bergoglio acerca daquele que seria eleito para dirigir a Igreja: "um homem que, a partir da contemplação de Jesus Cristo (...) ajude a Igreja a sair de si para as periferias existenciais". ${ }^{224}$ Com a eleição de Francisco, a expectativa se cumpriu e a preocupação com as periferias tem sido a tônica de seu pontificado.

De acordo com Dom Cláudio Hummes, OFM, arcebispo emérito de São Paulo, esta "Igreja em saída" é uma das metas que o papa mais acalenta: uma Igreja em movimento, direcionada às periferias e que não se acomoda na sacristia, apenas administrando os resultados colhidos com a evangelização, na medida em que, fora de seus muros, há milhares que sofrem esperando e clamando por salvação. Para Dom Cláudio, assim como para D. Ortega, quando o papa encoraja a Igreja para "ir às periferias da existência", ele pensa tanto nas periferias geográficas, como as periferias das cidades ou do campo, quanto nas periferias

223 Disponível em: https://leonardoboff.wordpress.com/2017/04/08/o-que-significa-uma-igreja-emsaida-segundo-o-papa-francisco/. Acesso em: 12 nov 2017.

224 Disponível em: http://www.ihu.unisinus.br/518772-esta-e-a-intervencao-magistral-do-cardealbergoglio-no-pre-conclave. Acesso em: 12 nov 2017. 
existenciais, onde se encontram pessoas desesperadas, deprimidas, tristes, atemorizadas, interiormente vazias, que perderam o sentido da vida e se sentem abandonadas, doentes físicos ou psíquicos, pecadores que não sentem coragem ou possibilidade de se libertar do mal em que estão envolvidos etc. As periferias, em geral, são de alguma forma invisíveis, porque não são vistas e não existe um interesse em vê-las ou torná-las visíveis. ${ }^{225}$

Para Guzman Carriquiry Lecour, Vice-Presidente da Comissão Pontifícia para a América Latina, que esteve ao lado do Cardeal Bergoglio durante o V CELAM de Aparecida, em 2007, o então futuro Papa teve um papel decisivo na comissão responsável pela elaboração do documento final, que foi por ele presidida. O "discípulo missionário" proposto por Francisco na Exortação Apostólica Evangelii Gaudium, surge já em Aparecida, mostrando e propando um povo que é discípulo e missionário de Cristo e que enfrenta toda a realidade da América Latina e do mundo em geral sob esse olhar cristão e pastoral. Na medida que a Evangelli Gaudium é um documento de um pastor que se tornou pastor universal, os critérios fundamentais de Aparecida se encontram também na eclesiologia de Francisco como proposta para a Igreja Universal. ${ }^{226}$

A visão de Francisco acerca do que a Igreja, já sentida no Documento do CELAN de Aparecida aparece de forma contundente neste trecho da Exortação Apostólica Evangelli Gaudium:

(...) Prefiro uma Igreja acidentada, ferida e enlameada por ter saído pelas estradas a uma Igreja enferma pelo fechamento e pela comodidade de se agarrar às próprias seguranças. Não quero uma Igreja preocupada em ser o centro, e que acaba presa num emaranhado de obsessões e procedimentos. Se alguma coisa nos deve santamente inquietar e preocupar a nossa consciência é que haja tantos irmãos nossos que vivem sem a força, a luz e a consolação da amizade com Jesus Cristo, sem uma comunidade de fé que os acolha, sem um horizonte de sentido e de vida. Mais do que o temos de falhar, espero que nos mova o medo de nos encerrarmos nas estruturas que nos dão uma falsa proteção, nas normas que nos transformam em juízes implacáveis, nos hábitos em que nos sentimos tranquilos, enquanto lá fora há uma multidão faminta. ( $E G$ n.49)

\subsection{2}

Um Igreja em diálogo com o mundo e com a sociedade

225 HUMMES, Grandes metas do papa Francisco, p.23.

${ }^{226} \mathrm{http}$ ://www.ihu.unisinos.br/78-noticias/568256-dez-anos-depois-de-aparecida-carriquiry-alinasceu-o-pontificado-de-bergoglio 
De acordo com França Miranda, “a longa formação humana e intelectual, própria dos jesuítas, a preocupação da ordem em estar presente e atuante nos mais variados setores da cultura e da sociedade, a ampla diversidade de seus membros, o espírito crítico diante de situações herdadas"227 dão características bem particulares ao espírito evangelizador da Ordem: o realismo, o equilíbrio, a empatia com o diferente, a sensibilidade pastoral, a compaixão diante do sofrimento, a reação no confronto com a injustiça, e mesmo a criatividade.

As Normas Complementares da Companhia de Jesus, promulgadas em 1995, por ocasião da revisão completa do direito próprio dos jesuítas ${ }^{228}$, que teve por objetivo atender às necessidades dos tempos atuais, "conservando, em

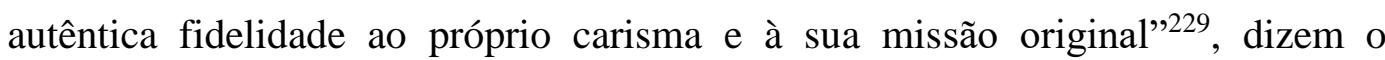
seguinte sobre a missão atual da Ordem:

A missão atual da Companhia é a participação na missão da Igreja evangelizadora na sua totalidade, cujo fim é a realização do Reino de Deus em toda a sociedade humana, não só na vida futura, mas também no presente. Esta missão, segundo o papa João Paulo II (Cart. encícl. Redemptoris missio, n. 41, AAS 1991 p. 289), é "uma realidade unitária, mas complexa, e se desenvolve de diversas maneiras", integrando as dimensões do testemunho de vida, da proclamação, conversão, inculturação, edificação das igrejas locais, diálogo e promoção da justiça, querida por Deus. ${ }^{230}$

Hoje, como pode ser percebido a partir dos decretos das Congregações Gerais, o trabalho nas fronteiras, traço fundamental da missão da Companhia de Jesus, devido à globalização do mundo, abrange um espectro muito grande de frentes de ação que inclui, entre outras, o diálogo com o islamismo, a ajuda aos refugiados, a preocupação com a África e a presença na China, a evangelização numa cultura secularizada, a sensibilidade com as gritantes desigualdades sociais e a empatia com todos os grupos à margem da sociedade. Para França Miranda, a amplitude e profundidade das necessidades da sociedade atual fazem com que o jesuíta tenha consciência que, para um serviço missionário efetivo, é necessário conhecer e respeitar o ser humano em todas as suas dimensões, saber acolher

\footnotetext{
227 MIRADA, Francisco: papa e jesuíta. In: PASSOS e SOARES, Francisco: renasce a esperança, p.137.

${ }^{228}$ Esta revisão adaptou as Constituições às normas do direito universal da lgreja para os institutos religiosos. Estas normas estão definidas no Código do Direito Canônico de 1983, para a Igreja Latina, e no Código dos Cânones das Igrejas Orientais de 1993.

${ }^{229}$ Constituições da Companhia de Jesus. Prefácio da revisão da Constituições Gerais, n.2, p.15.

230 Constituições da Companhia de Jesus. Prefácio da revisão da Constituições Gerais. Normas Complementares. $7^{a}$ parte, cap. $1, \S 1$, n.245, p.315.
} 
inteligentemente os diversos contextos socioculturais, zelar pela qualidade de suas atividades, e acabam por trazer um diferencial para a missão evangelizadora da ordem. $^{231}$

Sobre o tema, a $35^{\mathrm{a}} \mathrm{CG}$ diz:

O novo contexto em que vivemos, hoje, a nossa missão, está marcado por profundas mudanças, por conflitos agudos e por novas possibilidades. Diz-nos o Santo Padre: “A vossa Congregação desenrola-se num período de grandes mudanças sociais, econômicas e políticas; de acentuados problemas éticos, culturais e ambientais, de conflitos de todos os gêneros; mas também de comunicações mais intensas entre os povos, de novas possibilidades de conhecimento e de diálogo, de profundas aspirações à paz. São situações que interpelam, profundamente, a Igreja Católica e sua capacidade de anunciar aos nossos contemporâneos a Palavra de esperança e salvação". ${ }^{232}$

Vivemos num mundo global. A $34^{\mathrm{a}}$ Congregação Geral assinalou as "consciências crescentes da interdependência de todos os povos, numa herança comum". Este processo continuou a um ritmo acelerado; como resultado, aumentou a nossa interligação. $\mathrm{O}$ seu impacto sentiu-se profundamente em todas as áreas da nossa vida e é sustentado por estruturas culturais, sociais e políticas inter-relacionadas, que afetam o núcleo da nossa missão de fé e de justiça e todos os aspectos do nosso diálogo com a religião e com a cultura. (...) Neste mundo globalizado marcado por grandes mudanças, queremos aprofundar a nossa compreensão do chamamento a servir a fé, a promover a justiça e dialogar com a cultura e com outras religiões, à luz do mandato apostólico e estabelecer relações justas com Deus, uns com os outros e com a Criação. (...) Essa tradição dos jesuítas construírem pontes em situações de fronteira torna-se crucial para o mundo hoje. ${ }^{233}$

Já a $36^{\mathrm{a}} \mathrm{CG}$ completa:

A colaboração com outros é a única maneira que tem a Companhia de Jesus de realizar a missão que lhe foi confiada. Esta parceria na missão inclui aqueles que professam como nós a fé cristã, os que pertencem a diferentes religiões, e as mulheres e homens de voa vontade que, como nós, desejam colaborar na obra reconciliadora de Cristo. ${ }^{234}$

Esta consciência é facilmente detectável no pontificado de Francisco. Na opinião de França Miranda, existe em sua eclesiologia uma clara preocupação em conhecer, respeitar e levar a sério o ser humano concreto a quem a Igreja se dirige. É possível se perceber no papa a consciência de que o homem concreto é diverso e

231 Cf. MIRANDA, Francisco: papa e jesuíta. In: PASSOS e SOARES, Francisco: renasce a esperança, p.137.

232 Alocução, § 2 (Ref. nota constante da 34를 $\mathrm{CG}$ ) Dec. 3, n.8, p.110.

233 Decretos da Congregação Geral XXXV, Decreto 3, n.8, 9 e17, p.110 a 114.

234 Decretos da $36^{\underline{a}}$ Congregação Geral, Decreto 1, n.36, p.51. 
que a Igreja precisa evitar um discurso universal, idealista e padronizado se quer levar a mensagem cristã a toda humanidade. ${ }^{235}$

Em seu discurso aos membros da comunidade da revista La Civiltà Cattolica, o próprio papa deixa transparecer sua posição em consonância com a tradição dos jesuítas de serem pontes ${ }^{236}$, como afirmado no trecho da $35^{\text {a }} \mathrm{CG}$ acima citado:

(...) a vossa tarefa principal, não consiste em construir muros, mas pontes; em estabelecer diálogo com todos os homens (...) São numerosos os assuntos humanos a debater e compartilhar, e no diálogo é sempre possível aproximar-se da verdade, que é dádiva de Deus, e enriquecer-se reciprocamente. Dialogar significa estar persuadidos de que o outro tem algo de bom para dizer; reservar espaço ao seu ponto de vista, à sua opinião, às suas propostas, obviamente sem cair no relativismo. E para dialogar é preciso abaixar as defesas e abrir as portas. Continuar o diálogo com as instituições culturais sociais e políticas, também para oferecer a vossa contribuição para a formação de cidadãos que tenham a peito o bem de todos e trabalhem para o bem comum. ${ }^{237}$

Anteriormente, logo após ter sido escolhido papa, em um encontro com o

Corpo Diplomático, Francisco já havia tocado no mesmo tema:

Um dos títulos do Bispo de Roma é Pontífice, isto é, aquele que constrói pontes, com Deus e entre os homens. Desejo precisamente que o diálogo entre nós ajude a construir pontes entre todos os homens, de modo que cada um possa encontrar, no outro, não um inimigo nem um concorrente, mas um irmão que se deve acolher $\mathrm{e}$ abraçar. Além disso, as minhas próprias origens impelem-me a trabalhar por construir pontes. Na verdade, como sabeis, a minha família é de origem italiana; e assim está sempre vivo em mim este diálogo entre lugares e culturas diferentes, entre um extremo do mundo e outro, atualmente cada vez mais próximos, interdependentes e necessitados de se encontrarem e criarem espaços de autêntica fraternidade (...) Lutar contra a pobreza, tanto material como espiritual, edificar a paz e construir pontes: são como que os pontos de referimento para um caminho que devemos percorrer. ${ }^{238}$

Na visão de França Miranda, tudo isto só será possível se houver um esforço sério de enculturação ${ }^{239}$ da fé, que vinha sendo retardada e obstaculizada, nos últimos anos, devido a uma excessiva centralização na Igreja. Segundo o

\footnotetext{
${ }^{235} \mathrm{Cf}$. MIRANDA, Francisco: papa e jesuíta. In: PASSOS e SOARES, Francisco: renasce a esperança, p.137. 236 Vide nota 225.

237 Disponível em: http://w2.vatican.va/content/francesco/pt/speeches/2013/june/documents/papafrancesco_20130614_la-civilta-cattolica.html. Acesso em: 12 nov 2017.

238 Disponível em: https://w2.vatican.va/content/francesco/pt/speeches/2013/march/documents/ papa-francesco_20130322_corpo-diplomatico.html. Acesso em: 12 nov 2017.

239 Mario de França Miranda usa o termo "enculturação", conforme o Vocabulário Ortográfico da Língua Portuguesa, da Academia Brasileira de Letras, enquanto outros autores preferem "inculturação". Neste trabalho vamos utilizar os termos de acordo com a preferência dos autores.
} 
teólogo, o papa Francisco está consciente de que o ser humano concreto só existe dentro de um contexto sociocultural determinado e que deverá zelar para que a linguagem da igreja possa ser devidamente entendida por nossos contemporâneos das mais diversas regiões do planeta, sabendo renovar expressões e práticas na fidelidade à tradição da Igreja. ${ }^{240}$

O próprio Francisco, em seu discurso aos bispos presentes na Reunião Geral de Coordenação aos bispos responsáveis pelo CELAM, durante a JMJ, no Rio de Janeiro, disse o seguinte:

\begin{abstract}
A resposta às questões existenciais do homem de hoje, especialmente das novas gerações, prestando atenção à sua linguagem, implica uma mudança fecunda que devemos realizar com a ajuda do Evangelho, do Magistério e da Doutrina Social da Igreja. Os cenários e areópagos são os mais variados. Por exemplo, em uma mesma cidade, existem vários imaginários coletivos que configuram "diferentes cidades". Se continuarmos apenas com os parâmetros da "cultura de sempre", fundamentalmente uma cultura de base rural, o resultado acabará anulando a força do Espírito Santo. Deus está em toda a parte; há que saber descobri-lo pra poder anunciá-lo no idioma dessa cultura; e cada realidade, cada idioma tem um ritmo diferente. ${ }^{241}$
\end{abstract}

Segundo Marcelo Barros, a Igreja, através de Francisco, retomou um diálogo fraterno e amoroso com a humanidade. Este diálogo havia sido iniciado no final da década de 1950 pelo então papa João XXIII, que convocou o Concílio Vaticano II, mas, na década de 1980, foi praticamente rompido e substituído por uma postura dogmática e autoritária. ${ }^{242}$ Para Carlos Josaphat P. de Oliveira, estas conquistas do Concílio que Francisco quer novamente trazer para a vida da Igreja desenham os traços de uma Igreja de comunhão, de diálogo de participação, de colegialidade e de ecumenismo, portadora de uma proposta ao mundo, que começa por um abraço afetuoso a toda a humanidade. ${ }^{243}$

Francisco Tomáz Aquino Junior diz que o Concílio Vaticano II abriu a Igreja ao mundo e ajudou-a a compreender que não existe para si mesma, mas para o mundo e, na esteira deste, a Conferência Episcopal Latino Americana de Medellín deu mais um passo e ajudou-a entender que o mundo para o qual deve se

240 Cf. MIRANDA, Francisco: papa e jesuíta. In: PASSOS e SOARES, Francisco: renasce a esperança, p.137-8.

241 Disponível em: http://w2.vatican.va/content/francesco/pt/speeches/2013/july/documents/papafrancesco $20130728 \mathrm{gmg}$-celam-rio.html. Acesso em: 13 nov 2017.

242 Disponível em: http://www.ihu.unisinos.br/78-noticias/561068-a-luta-do-papa-francisco. Acesso em: 12 nov 2017.

243 JOSAPHAT, Uma reforma evangélica na plena fidelidade criativa ao Vaticano II. In: PASSOS e SOARES, Francisco: renasce a esperança, p.224. 
abrir não é um mundo homogêneo, mas um mundo marcado por profundas desigualdades sociais que produz miséria e sofrimentos em meio a muitas conquistas. Segundo este autor, o papa Francisco, ao propor que a Igreja estabeleça um diálogo com o mundo e com a sociedade, recupera as grandes intuições do Concílio e do CELAN de Medellín, esquecidas nos últimos anos, fazendo uma nova síntese, a partir da qual procura orientar os rumos e a atuação da Igreja em direção aos mais pobres. Na visão de Aquino, a figura do papa Francisco tem impactado o mundo porque toca naquilo que o mundo mais carece nesse momento, que é justiça, paz, fraternidade. Por ser uma das grandes reservas éticas, espirituais e humanitárias do mundo, o papa é hoje uma referência não só para os cristãos, mas para outras religiões. ${ }^{244} \mathrm{O}$ mundo atual apresenta à Igreja grandes desafios que devem ser enfrentados, entre eles, a relação com a política, o pluralismo religioso, o diálogo inter-religioso, o cristianismo numa sociedade plural e a pastoral social, e o Concílio continua oferecendo bases importantes para se pensar estas relações. ${ }^{245}$

No discurso que fez, em 2013, no encontro com líderes políticos, artistas, intelectuais e diplomatas e autoridades brasileiras, por ocasião da Jornada Mundial da Juventude, no Rio de Janeiro, o papa, citando Alceu de Amoroso Lima, mostrou a importância que dá ao diálogo e sua preocupação em convidar aqueles que influenciam a sociedade a fazer o mesmo:

Todos aqueles que possuem um papel de responsabilidade em uma nação são chamados a enfrentar o futuro "com os olhos calmos de quem sabe ver a verdade", como dizia o pensador brasileiro Alceu Amoroso Lima. Queria considerar três aspectos deste olhar calmo, sereno e sábio: primeiro, a originalidade de uma tradição cultural; segundo, a responsabilidade solidária para construir o futuro; e terceiro, o diálogo construtivo para encarar o presente. ${ }^{246}$

Na ocasião, Francisco também destacou a importância do diálogo para o desenvolvimento e crescimento de uma sociedade e a necessidade de uma "cultura do encontro":

\footnotetext{
244 Disponível em: http://www.jesuitasbrasil.com/newportal/2017/09/13/livro-de-professor-deteologia-e-lancado-na-unicap. Acesso em: 12 nov 2017.

245 Disponível em: http://www.unicap.br/assecom1/livro-de-professor-de-teologia-aborda-a-relacaoentre-fe-igreja-e-sociedade/. Acesso em: 12 nov de 2017.

246 Disponível em: http://www.rj.gov.br/web/imprensa/exibeconteudo?article-id=1692458. Acesso em: 12 nov 2014.
} 
O diálogo entre as gerações, o diálogo com o povo, a capacidade de dar e receber, permanecendo abertos à verdade. Um país cresce quando dialogam de modo construtivo as suas diversas riquezas culturais: cultura popular, cultura universitária, cultura juvenil, cultura artística e tecnológica, cultura econômica e cultura familiar e cultura da mídia. ${ }^{247}$

\subsection{3 \\ Uma Igreja que promove a liberdade cristã}

Desde a fundação da Companhia de Jesus, Santo Inácio deu grande importância à "lei interior da caridade e do amor, expressa e escrita pelo Espírito Santo nos corações" 248 , ainda que sem relegar a segundo plano os ensinamentos e leis da Igreja. ${ }^{249}$ De acordo com França Miranda, com certeza, ao redigir as Constituições da Companhia, Inácio levou em consideração todo o Magistério de Roma, mas antes de promulgá-las, teve o cuidado de passá-las por experiências concretas e positivas feitas por jesuítas de várias partes do mundo. ${ }^{250}$ Mesmo assim, boa parte destas regras, como estão apresentadas nas Constituições, dão margem a que o Superior, a partir de um discernimento pessoal da vontade de Deus, tenha liberdade de decidir a favor ou contra sua aplicação e agir da forma que lhe parecer mais conveniente. ${ }^{251} \mathrm{Na}$ visão de F. Miranda, este respeito à liberdade pessoal, a importância dada à experiência e à disponibilidade para o agir de Deus é o que mais caracteriza o modo de proceder de Inácio e de seus seguidores. $^{252}$

De acordo com Raísa Suena Soares Lopes, o discernimento espiritual inaciano direciona o exercitante sempre para algo concreto e possível, profético e atual e deve ultrapassar a mera percepção de um bom desejo, de um bom sentimento. Neste processo, é preciso buscar perceber para onde o Senhor está movendo e atraindo no momento presente, pois cada um é chamado a ocupar o espaço de liberdade que recebeu. ${ }^{253}$ Assim sendo, o discernimento, dentro da

\footnotetext{
247 Disponível em: http://www.rj.gov.br/web/imprensa/exibeconteudo?article-id=1692458. Acesso em: 12 nov 2014.

248 Constituições da Companhia de Jesus. Proêmio das Constituições, n.134, §1, p.75, apud MIRANDA, A Reforma de Francisco: fundamentos teológicos, p.178.

249 Cf. MIRANDA, Francisco: papa e jesuíta. In: PASSOS e SOARES, Francisco: renasce a esperança, p.138.

250 Cf. idem, A Reforma de Francisco: fundamentos teológicos, p.178.

251 Cf. idem, Francisco: papa e Jesuíta. In: PASSOS e SOARES, Francisco: renasce a esperança, p.138.

252 MIRANDA, A reforma de Francisco: fundamentos teológicos, p.178.

253 LOPES, Discernimento Inaciano: a liberdade humana respondendo a Deus, p.70.
} 
espiritualidade inaciana, se torna então um elemento fundamental e uma das ferramentas mais necessárias para o exercício da liberdade.

Sobre o discernimento, a $36^{\mathrm{a}}$ Congregação diz:

Discernimento, um dom precioso de Inácio, é parte integrante de nossa vida apostólica tanto pessoal como de corpo. Começa com a contemplação de Deus que trabalha em nosso mundo e nos permite tirar mais fruto ao unir nossos esforços aos desígnios de Deus. É "o que nos enraíza na Igreja, na qual o Espírito atua e reparte sua diversidade de carismas para o bem comum" (papa Francisco, discurso à CG36, 24 de outubro de 2016). ${ }^{254}$

Na visão do papa Francisco, uma das coisas que Santo Inácio mais trabalhou interiormente foi o discernimento, segundo ele, um instrumento de luta para se conhecer melhor Deus e segui-lo mais de perto. O discernimento inaciano acontece sempre na presença de Deus, vendo os sinais, escutando as coisas que acontecem, o sentir das pessoas, especialmente dos mais pobres. E, para ser propriamente desenvolvido e lançar as bases de uma mudança verdadeira e eficaz, requer tempo e maturidade. ${ }^{255}$ Para o papa, só uma pessoa que desenvolveu uma maturidade espiritual é que pode ser considerada uma pessoa realmente livre. ${ }^{256}$

Na mesma linha de Francisco, França Miranda afirma que a espiritualidade inaciana respeita a liberdade da pessoa em seu relacionamento com Deus, mas, para tanto, exige formação e maturidade espiritual e humana para ser praticada. Para o teólogo, no entanto, apesar de não ser uma espiritualidade recomendada para qualquer um sem maiores cuidados, ela aponta para um traço da fé cristã que ficou silenciado, por muito tempo, na vida da Igreja: o da liberdade do cristão gozar da maioridade não só na família e na sociedade, como também na Igreja, onde deve encontrar espaço livre para se expressar, manifestar como vive sua fé, as dificuldades que encontra e até as insuficiências que experimenta por parte da própria instituição. $^{257}$ A mediação salvífica da Igreja não pode e não deve acarretar a supressão de um relacionamento pessoal com Deus por parte de seus membros. Hoje, mais do que nunca, a fé significa uma opção livre, consciente do seu risco e do abandono a Deus que ela implica. ${ }^{258}$

\footnotetext{
$25436^{\text {a }}$ Congregação Geral, Decreto 2, n.4, p.56.

255 SPADARO, Entrevista exclusiva do papa Francisco, p.10-11.

256 Cf. MIRANDA, A reforma de Francisco: Fundamentos teológicos, p.177.

257 Cf. idem, Francisco: papa e jesuíta. In: PASSOS e SOARES, Francisco: renasce a esperança, p.139.

258 lbidem, p.139-40.
} 
$\mathrm{Na}$ visão de John O’Malley, SJ, Francisco se mostra como uma pessoa eminentemente livre que parece dizer e fazer o que faz simplesmente porque lhe parece certo assim agir. Ele é livre por dentro e é difícil não atribuir essa liberdade ao resultado de suas experiências advindas dos Exercícios Espirituais. Os Exercícios têm por objetivo ajudar as pessoas a chegarem à liberdade de fazer a única coisa que é realmente necessária: a vontade de Deus. Ao alcançar este objetivo, a pessoa passa a viver sempre livre por dentro. ${ }^{259}$

Para Victor Codina, Francisco, ao valorizar a liberdade interior, inaugurou um novo estilo de exercer o Primado romano:

Ele não é teólogo profissional e não impõe sua própria teologia, mas é sobretudo pastor. Abriu as portas da Igreja, deseja uma Igreja que saia às ruas e cheire a ovelha, que não exclua mas que acolha e seja sacramento de misericórdia, uma Igreja que seja dialogante, não autorreferencial, pobre e dos pobres, que viva a alegria do Evangelho e acredite na novidade sempre surpreendente do Espírito. O clima eclesial mudou nestes anos, há maior liberdade, pode-se respirar melhor. ${ }^{260}$

Na homília do dia 27 de abril de 2017 feita na Casa Santa Marta, Francisco afirmou que, muitas vezes na história, a própria Igreja que condenou o racionalismo caiu ela mesma numa teologia do "pode-não pode", do "até aqui-até lá”, esquecendo a força e a liberdade do Espírito. Para o papa, em um pensar bem inaciano, esse renascer pelo Espírito é o lugar de onde provém nossa liberdade, a franqueza da pregação e o anúncio de que Jesus Cristo é o Senhor. Nesta ocasião, invocou aos presentes:

Peçamos ao Senhor essa experiência do Espírito que vai e vem, e nos leva em frente, do Espírito que nos dá a unção da fé, a unção das concretudes da fé: "O vento sopra onde quer, e ouves a sua voz, mas não sabes de onde vem, nem para onde vai. Assim é todo aquele que nasceu do Espírito". Ouve "a voz, segue o vento, segue a voz do Espírito, sem saber aonde vai acabar. Porque fez uma opção pela concretude da fé e o renascimento no Espírito". Deus "nos dê esse Espírito pascal de ir nas estradas do Espírito, sem compromissos, sem rigidez, com a liberdade de anunciar Jesus Cristo como Ele veio: na carne. ${ }^{261}$

Para os estudantes de escolas jesuítas, em 7 de junho de 2013, ele afirmou que a liberdade e o serviço são os valores fundamentais do cristão:

\footnotetext{
259 Disponível em: www.ihu.unisinos.br/539064-papa-francisco-jesuíta-e-então. Acesso em: 12 nov 2017.

260 Disponível em: http://www.ihu.unisinos.br/78-noticias/555648-os-teologos-malditos-e-o-papafrancisco-artigo-de-victor-codina. Acesso em: 12 nov 2017.

261 Disponível em: http://www.ihu.unisinos.br/78-noticias/566923-as-vezes-a-igreja-caiu-em-umateologia-do-pode-e-do-nao-pode. Acesso em: 12 nov 2017.
} 
Acima de tudo: sejam pessoas livres! O que eu quero dizer? Talvez se pense que a liberdade é fazer tudo o que se quer, ou se aventurar em experiências-limite para sentir a embriaguez e vencer o tédio. Essa não é liberdade. Liberdade significa saber refletir sobre o que fazemos, saber avaliar o que é bom e o que é ruim, aqueles que são os comportamentos que fazem crescer, o que significa escolher sempre o bem. Nós somos livres para o bem. E nisso não tenham medo de ir contra a corrente, mesmo que não seja fácil! Ser livres para escolher sempre o bem é comprometedor, mas lhes tornará pessoas que têm a espinha dorsal, que sabem enfrentar a vida, pessoas com coragem e paciência. ${ }^{262}$

\subsection{4 \\ Uma Igreja voltada para os pobres}

Segundo França Miranda, Santo Inácio de Loyola fundou a ordem dos jesuítas numa época de decadência da Igreja ${ }^{263}$, que estava expressa de forma bem visível na vida mundana de suas autoridades e mesmo do clero em geral. Em reação a esta situação, Inácio sempre insistiu que seus seguidores tivessem num estilo de vida sóbrio, na experiência de se confiar a Deus, no pregar a pobreza, na simplicidade funcional das casas, na experiência pessoal de cada um com os pobres e os necessitados. ${ }^{264}$

De acordo com as Constituições da Companhia de Jesus, a pobreza é um esforço do homem, "no seguimento radical de Cristo humilde e pobre, para alcançar a liberdade de todo afeto desordenado, que é condição para um amor intenso e desembaraçado a Deus e ao próximo". ${ }^{265}$

Também segundo as Constituições, a $31^{\mathrm{a}} \mathrm{CG}$ afirmou que a pobreza na Companhia é apostólica, de modo que todo o apostolado deve ser "informado pelo espírito da pobreza"266.

A Companhia tem consciência que a busca de eficácia, característica da ordem, é responsável por contínuas tensões com o imperativo da pobreza e com a carência de recursos própria do trabalho com os mais desprovidos da sociedade, que devem ser resolvidas pelo discernimento da vontade de Deus. ${ }^{267}$

\footnotetext{
262 Disponível em: http://www.ihu.unisinos.br/520830-sejam-pessoas-livres-a-audiencia-do-papaaos-estudantes-das-escolas-jesuitas. Acesso em: 12 nov 2017.

263 Embora em uma época conturbada houve vários expoentes,tais como: Inácio de Loyola, Francisco Xavier, Tereza D'Ávila, João da Cruz sem esquecer o próprio Concílio de Trento.

264 Cf. MIRANDA, Francisco: papa e jesuíta. In: PASSOS e SOARES, Francisco: renasce a esperança, p.140.

265 Constituições da Companhia de Jesus. Normas Complementares. 6 ${ }^{\underline{a}}$ parte. Seção IV, n.157 p.287-8.

${ }^{266}$ Congregação Geral XXXI, Decreto 18, n.4, Introdução, p.148.

267 Cf. MIRANDA, Francisco: papa e jesuíta. In: PASSOS e SOARES, Francisco: renasce a esperança, p.140-1.
} 
Sobre o tema, as Constituições dizem o seguinte: "A eficiência apostólica e o testemunho da pobreza apostólica são dois valores intimamente relacionados e em permanente tensão; isto vale não só para os indivíduos, mas também para as instituições apostólicas". ${ }^{268}$ A pobreza dentro da Companhia é "condição de credibilidade apostólica, como (...) expressão total em Deus e (...) gratuidade no serviço aos outros", enquanto torna os jesuítas "testemunhas do amor gratuito de Deus que se entregou por nós o seu Filho no despojamento total da encarnação e da cruz." 269

Embora os jesuítas sejam preparados para assumir qualquer missão em qualquer lugar do mundo onde sejam necessários, na esteira do Vaticano II, as Normas Complementares das Constituições já afirmam o serviço aos pobres como opção preferencial da Companhia, devendo esta, para tanto, “encontrar expressões concretas, direta e indiretamente na vida de cada um de seus membros, bem como na orientação de seus trabalhos e na seleção de seus ministérios". ${ }^{270}$

Esta mesma preocupação com os pobres se faz sentir desde o primeiro momento pelo atual papa. De acordo com Maria Clara Bingemer, seu estilo simples e despojado acena para o fato que, em seu pontificado, a preocupação central é com os pobres, os preferidos de Deus que deveriam ser sempre a primeira e preferencial opção da Igreja de Cristo. Como o próprio Francisco se intitula, ele é o papa "do fim do mundo"271, lugar onde a pobreza e a injustiça fazem diariamente seu trabalho predatório sobre as vidas humanas. ${ }^{272}$

No discurso de Francisco aos membros da $36^{\mathrm{a}} \mathrm{CG}$, esta preocupação inaciana de servir aos pobres fica bastante evidente:

O Senhor que olha para nós com misericórdia e nos escolhe, envia-nos para fazer chegar, com toda a sua eficácia, a mesma misericórdia aos mais pobres, aos pecadores, aos descartados e crucificados do mundo atual que sofrem a injustiça e a violência. Só se experimentarmos ao vivo essa força reparadora em nossas chagas (chagas com nome e sobrenome), como pessoas e como corpo, perderemos o medo de nos deixar comover pela imensidão do sofrimento dos nossos irmãos e nos

268 Constituições da Companhia de Jesus. Normas Complementares. 6ª parte. Seção 4, n.159, § 2, p.288.

269 Constituições da Companhia de Jesus. Normas Complementares. 6aㅗ parte. Seção 4, n.160 p.288.

270 Constituições da Companhia de Jesus. Normas Complementares. 6⿳亠丷厂 parte. Seção 4, n.163, p.289.

271 Disponível em: https://w2.vatican.va/content/francesco/pt/speeches/2013/march/documents/ papa-francesco 20130313 benedizione-urbi-et-orbi.html. Acesso em: 12 nov 2017.

272 BINGEMER, disponível em: http://domtotal.com/colunas/detalhes.php?artld=3497 
lançaremos a caminhar pacientemente com nossos povos, aprendendo deles o modo de melhor ajudá-los e servi-los. ${ }^{273}$

Francisco também defende uma Igreja pobre e, no diálogo que teve com os jesuítas reunidos na $36^{\mathrm{a}} \mathrm{CG}$, lembrou que Inácio de Loyola se refere à pobreza com duas palavras,

Porque, para Inácio - e estas são as duas palavras-chave que ele usa -, a pobreza é mãe e muro. A pobreza gera, é mãe, gera vida espiritual, vida de santidade, vida apostólica. E é muro, defende. Quantos desastres eclesiais começaram por falta de pobreza: mesmo fora da Companhia, refiro-me a toda a Igreja em geral. Quantos escândalos, os quais, infelizmente (...) nascem do dinheiro. Eu acredito que Santo Inácio realmente teve uma grande intuição. Na visão inaciana da pobreza, temos uma fonte de inspiração que nos será de ajuda. ${ }^{274}$

De acordo com Juan Carlo Scanonne SJ, no entanto, Francisco, para além da sua influência inaciana, também é muito marcado pelo Teologia do Povo argentina, uma das quatro correntes da Teologia da Libertação latino-americana, na visão de muitos teólogos da libertação, entre eles, João Batista Libânio.

Segundo Scanonne, a partir do momento em que foi eleito, o Papa tem realizado gestos simbólicos, dado entrevistas, falada como chefe da Igreja em manifestações que remetem à Teologia do Povo e que dão margem a que seja estabelecida uma convergência entre seu pensamnteo e a perspectiva pastoral desta teologia. A própria Evangelii Gaudium definiu uma espécie de "roteiro" de seu pontificado que aponta para esta direção, assim como a predileção que demonstra pela expressão "povo fiel”, e que, em sua visão, significa o povo que em seu conjunto anuncia o Evangelho.

Em sua primeira aparição como Papa, ao pedir a benção do povo, já mostra sua ligação com a Teologia do Povo que concebe a Igreja como povo fiel de Deus, reconhecendo o "sensus fidei" do Povo e o lugar do leigo no mesmo.

Na visão deste Scanonne, para a Teologia do Povo, a categoria "povo" é ambígua, não pela pobreza, mas pela riqueza, podendo se referir tanto ao povonação como às classes e setores sociais populares. No entanto, a acepção primordial é aquela que entende "povo" a partir da unidade plural de uma cultura comum, enraizada em uma história comum e projetada para um bem comum

273 Congregação Geral XXXVI, Doc. Complementares. discurso de Sua Santidade o papa Francisco à CG 36, p.99.

${ }^{274}$ Congregação Geral XXXVI, Doc. Complementares. Diálogo do papa Francisco com os jesuítas reunidos na CG 36, p.115. 
compartilhado. Nesta concepção, a dimensão histórica é fundamental e exige dos pastores e políticos um sério discernimento dos "sinais dos tempos" na vida do povo e dos povos que, para os fieis, são também indicadores da vontade previdente de Deus.

De acordo com o parágrafo 44 do Documento de Puebla, são os pobres que conservam e melhor deixam transparecer a cultura própria de seu povo, sua memória histórica como algo estrutural de sua vida e convivência, que possuem um projeto histórico comum de justiça e paz, já que são eles que vivem oprimidos por uma situação de injustiça estrutural e de violência institucionalizada. Sendo este, portanto, o motivo porque, na América Latina, a opção pelos pobres e pela cultura coincidem. ${ }^{275}$

Para Bingemer, o pontificado de Francisco gerou o retorno dos pobres e dos esquecidos ao centro do pensamento e do discurso da Igreja. Segundo a teóloga, uma das características que mais impressionam e que parece ser a maior novidade deste pontificado é justamente sua preocupação com os pobres na vida e na missão da Igreja. ${ }^{276}$

Na visão de França Miranda, o papa Francisco tem defendido e lutado por uma Igreja mais simples, mais próxima das pessoas, mais humilde, mais voltada para os pobres e marginalizados da sociedade, na fidelidade ao exemplo de Jesus Cristo. Além disso, o fato do atual papa ser também oriundo do Terceiro Mundo, lugar onde se encontra a maior parte dos católicos e onde se experimentam na carne os sofrimentos humanos resultantes da política hoje vigente que "prioriza o lucro e a produtividade e não a pessoa humana, torna ainda mais incisivo o novo olhar da Igreja em direção aos excluídos". ${ }^{277}$

$\mathrm{Na}$ Exortação Apostólica Evangelii Gaudium, de novembro de 2013, falando sobre anúncio do Evangelho no mundo atual, Francisco diz:

Quando o apóstolo São Paulo foi ter com os apóstolos em Jerusalém para discernir "se estava a correr ou tinha corrido e vão" (Gal 2,2), o critério chave de autenticidade que lhe indicaram foi que não se esquecesse dos pobres (cf. Gal 2,10). Este critério era importante para as comunidades paulinas não se deixarem arrastar pelo estilo de vida individualista dos pagãos e tem grande atualidade no contexto de hoje, em que um novo paganismo individualista tende a desenvolver-

275 Cf. http://www.ihuonline.unisinos.br/artigo/5919-juan-carlos-scannone-3

276 BINGEMER, Esperança de futuro para a Igreja. In: PASSOS e SOARES, Francisco: renasce a esperança, p.246.

277 MIRANDA, Francisco: papa e jesuíta. In: PASSOS e SOARES, Francisco: renasce a esperança, p.142. 
se. A própria beleza do Evangelho nem sempre conseguimos manifestar adequadamente, mas há um sinal que nunca deve faltar a opção pelos últimos, por aqueles que a sociedade descarta e lança fora. (...) No coração de Deus, os pobres ocupam lugar preferencial, tanto que até Ele mesmo "se fez pobre" (2Co 8,9). Todo o caminho da nossa redenção está assinalado pelos pobres. (EG, 195 e 197) (27 $^{278}$

Logo após sua eleição, em audiência com os jornalistas, Francisco expressou seu grande desejo como papa, em continuidade com a intuição de João XXIII: "Como eu gostaria de uma Igreja pobre para os pobres"279. Segundo F. Aquino Jr., a expressão "Igreja dos pobres" é relativamente recente. Foi usada pelo papa João XXIII, pelo grupo que, no Concílio Vaticano II, ficou conhecido pelo mesmo nome, pela Conferência de Medellin e, principalmente, pela Teologia da Libertação. ${ }^{280}$ Como ele mesmo se intitulou, vindo do Sul, do fim do mundo, das latitudes onde imperam a desigualdade e a injustiça, Francisco é consciente que boa parte da humanidade vive em condições injustas de extrema pobreza e é, portanto, a estes que a Igreja deve servir prioritariamente, já que sua fé proclama que estes que o mundo desconsidera são, na verdade, os preferidos de Deus. ${ }^{281}$

O nome por ele escolhido é uma clara referência desta preocupação para com os pobres. Como explicou no encontro que teve com os jornalistas em $16 \mathrm{de}$ março de 2013, no momento da confirmação do seu nome durante o conclave, Dom Cláudio Hummes, que estava ao seu lado, o abraçou e beijou, dizendo: "Não te esqueças dos pobres”. Estas palavras ficaram ecoando dentro dele até que fez a associação com Francisco de Assis. ${ }^{282}$ Ao tomar Francisco de Assis como referência, o papa já apontava para a uma profunda reforma na Igreja, fundada no Evangelho de Jesus Cristo, o Evangelho do Reino, cuja característica fundamental é a justiça aos pobres, oprimidos e fracos. ${ }^{283}$

Para F. Miranda, o cuidado com os pobres tem sido uma constante do magistério de Francisco, contribuindo para que a Igreja se desfaça da pesada herança do passado, do poder em vez do serviço, do autoritarismo em vez da fraternidade, da centralização em vez da comunhão, da vaidade em vez da humildade, da solenidade em vez da simplicidade, da imposição em vez do

\footnotetext{
278 HUMMES, Grandes metas do papa Francisco, p.16.

279 Disponível em: http://www.ihu.unisinos.br/171-noticias/noticias-2013/518498-quero-uma-igrejapobre-para-os-pobres. Acesso em: 12 nov 2017.

${ }^{280}$ AQUINO Jr., Os pobres e a pobreza como carisma fundante da Igreja de Jesus. In: PASSOS e SOARES, Francisco: renasce a esperança, p.218.

281 Disponível em: http://domtotal.com/colunas/detalhes.php?artld=3497. Acesso em: 11 jan 2018.

${ }^{282}$ AQUINO Jr., op. cit., p.214-5.

283 Ibidem, p.221.
} 
diálogo, do falado em vez do vivido, das práticas religiosas em vez da opção de fé livre e pessoal. ${ }^{284}$

$\mathrm{Na}$ opinião de Aquino Jr., com este posicionamento, Francisco vai dando uma nova imagem e um novo rumo ao ministério do bispo de Roma em sua missão de "presidir na caridade" a unidade das igrejas. Essa missão, assim, tem, para o teólogo, "cheiro de Evangelho" e é sinal da nova primavera eclesial que é regada pelas fontes mais puras do Evangelho: Jesus, o Reino e os pobres. ${ }^{285}$

Ao transformar o dia 19 de novembro como o Dia Mundial dos Pobres, Francisco foi definitivo em seu comprometimento com este segmento da humanidade:

\begin{abstract}
Sabemos a grande dificuldade que há, no mundo contemporâneo, para se poder identificar claramente a pobreza. E todavia esta interpela-nos todos os dias com os seus inúmeros rostos vincados pelo sofrimento, a marginalização, a opressão, a violência, as torturas e a prisão, pela guerra, a privação da liberdade e da dignidade, pela ignorância e o analfabetismo, pela emergência sanitária e a falta de trabalho, pelo tráfico de pessoas e a escravidão, pelo exílio e pela migração forçada. A pobreza tem o rosto de mulheres, homens e crianças explorados para vis interesses, espezinhados pelas lógicas perversa do poder e do dinheiro. Como é impiedoso e nunca completo o elenco que se é constrangido a elaborar à vista da pobreza, fruto da injustiça social, da miséria moral, da avidez de poucos e da indiferença generalizada! Infelizmente, nos nossos dias, enquanto sobressai cada vez mais a riqueza descarada que se acumula nas mãos de poucos privilegiados, frequentemente acompanhada pela ilegalidade e a exploração ofensiva da dignidade humana, causa escândalo a extensão da pobreza a grandes setores da sociedade no mundo inteiro. Perante este cenário, não se pode permanecer inerte e, menos ainda, resignado. À pobreza que inibe o espírito de iniciativa de tantos jovens, impedindo-os de encontrar um trabalho, à pobreza que anestesia o sentido de responsabilidade, induzindo a preferir a abdicação e a busca de favoritismos, à pobreza que envenena os poços da participação e restringe os espaços do profissionalismo, humilhando assim o mérito de quem trabalha e produz: a tudo isso é preciso responder com uma nova visão da vida e da sociedade. ${ }^{286}$
\end{abstract}

\title{
3.3.5 \\ Uma Igreja que vive sua fé
}

França Miranda conta que, no século XVI, época da fundação da Companhia, a ação evangelizadora, principal objetivo da nova ordem dos jesuítas,

284 MIRANDA, Francisco: papa e jesuíta. In: PASSOS e SOARES, Francisco: renasce a esperança, p.141-142.

${ }^{285}$ AQUINO Jr., op. cit., p.215-6.

286 Disponível em: http://www.ihu.unisinos.br/78-noticias/568635-1-dia-mundial-dos-pobres-19-denovembro-mensagem-do-papa-francisco. Acesso em: 13 nov 2017. 
não se ajustava à visão daquele momento histórico que separava um tempo para contemplação e outro para a atividade pastoral. Para Inácio de Loyola, vida e oração se confundiam e formavam uma única realidade inseparável e, baseado em sua própria experiência, desenvolveu uma mística da ação caracterizada por "buscar e encontrar Deus em todas as coisas". Para que tal mística pudesse se realizar de forma efetiva, Inácio percebeu que era fundamental que houvesse uma real intenção de buscar Deus e não interesses próprios em todas atividades empreendidas. Para ele, só assim, a partir desta sintonia com a vontade de Deus e da iniciativa pessoal, é que seria possível se chegar a esta experiência de encontrar Deus em meio às ocupações de todo dia e aos trabalhos exigidos pela própria missão. Esta experiência de Deus em meio à vida cotidiana reabastece o apóstolo continuamente, sem que ele necessite interromper suas atividades. ${ }^{287}$

Ainda de acordo com este autor, esta mística da ação foi fundamental para expansão da Companhia de Jesus, uma ordem que pretendia marcar presença cristã em todos os âmbitos da sociedade e mesmo da realidade como um todo. Inácio de Loyola, através de sua experiência pessoal, rompeu com a separação existente na teologia de sua época, que excluía a graça de Deus da vida concreta e limitava-a aos atos religiosos. Para Inácio, Deus pode ser encontrado em qualquer setor da realidade e da vida, desde que o olhar e a atividade da pessoa se sintonizem com sua vontade de que tudo aconteça "para a maior glória de Deus" e que este olhar e agir cristão sejam alimentados por momentos de silêncio e meditação. ${ }^{288}$

De acordo com W. A. Barry, SJ e Robert Doherty, SJ, em seu livro Contemplativos em ação,

a espiritualidade jesuíta é um conjunto de tensões vivificadoras e criativas. Os jesuítas devem ser homens de oração, para quem os meios espirituais são primordiais, mas pede-se a eles que usem todos os meios naturais à disposição para o seu trabalho apostólico. Devem ser homens disciplinados, purificado ao apego imoderado aos valores mundanos, e, no, entanto, ativamente envolvidos no mundo; espera-se, na verdade, que encontrem Deus na sua atividade. ${ }^{289}$

Respondendo a uma pergunta de A. Spadaro sobre como procurar e encontrar Deus em todas as coisas, o próprio Francisco diz:

287 Cf. MIRANDA, Francisco: papa e jesuíta. In: PASSOS e SOARES, Francisco: renasce a esperança, p.142-3.

${ }^{288}$ Cf. ibidem, p.143.

${ }^{289} \mathrm{Cf}$. BARRY e DOHERTY, Contemplativos em ação, p.13. 
Encontrar Deus em todas as coisas não é um eureca empírico. No fundo, quando desejamos encontrar Deus, queremos constatá-lo de imediato com um método empírico. Assim não se encontra Deus. Ele se encontra na brisa ligeira sentido por Elias. Os sentidos que constatam Deus são os que Santo Inácio designa por "sentidos espirituais". Inácio pede que se abra a sensibilidade espiritual para encontrar Deus para além de uma abordagem puramente empírica. É necessária uma atitude contemplativa: é o sentir que se vai pelo bom caminho da compreensão e do afeto no que diz respeito às coisas e às situações. O sinal de que se está nesse bom caminho é o sinal da paz profunda, da consolação espiritual, do amor de Deus e de todas as coisas. ${ }^{290}$

Para França Miranda, a mística inaciana de "buscar e encontrar Deus em todas as coisas" tem levado o papa Francisco a fomentar a presença e o respeito da Igreja pelo mundo das ciências, pelas outras religiões e culturas, pelas demais Igrejas cristãs, pelo marginalizados e esquecidos da sociedade, pelos que lutam pela sustentabilidade do planeta, pelos que contribuem para a paz e a justiça. Através da vivência da mística da ação, ele tem sido presença atuante não para dominar e exercer o poder, mas para conhecer, colaborar e cerrar fileiras com os que lutam pela mesma causa, pela humanidade querida por Deus. ${ }^{291}$

De acordo com M. C. Bingemer, a partir de sua experiência fornecida pela mística dos jesuítas, Francisco tem tentado fazer com que a Igreja busque a própria conversão e retome o Concílio Vaticano II, como prioridade e centro de todo o agir eclesial ${ }^{292}$, libertando-se das engrenagens do poder e dos poderosos, rompendo os laços de uma moral autoritária e asfixiante. É possível perceber, em Francisco, um reconhecimento que a essência da missão confiada à Igreja é indicar à humanidade os rumos teológicos e éticos de sua caminhada, de seu destino histórico e transcendente. ${ }^{293}$ São dele as seguintes palavras:

Existe, de fato, a tentação de procurar Deus no passado ou no futuro. Deus está, certamente, no passado porque está nas pegadas que deixou. E está também no futuro como promessa. Entretanto, o Deus "concreto", digamos assim, é hoje. Por isso, os queixumes nunca, nunca, nos ajudam a encontrar Deus. As queixas de hoje de como o mundo anda 'bárbaro' acabam por fazer nascer dentro da Igreja desejos de ordem entendidos como pura conservação, defesa. Não. Deus deve ser encontrado hoje. Deus manifesta-se numa revelação histórica, no tempo. O tempo inicia processos, os espaços os cristalizam. Deus encontra-se no tempo, nos processos em curso. Devemos encaminhar processos, mais do que ocupar espaços.

290 Cf. SPADARO, Entrevista exclusiva do papa Francisco, p.27.

291 MIRANDA, Francisco: papa e jesuíta. In: PASSOS e SOARES, Francisco: renasce a esperança, p.144.

292 BINGEMER, Esperança de futuro para a Igreja. In: PASSOS e SOARES, Francisco: renasce a esperança, p.243-4.

293 JOSAPHAT, Uma reforma evangélica na plena fidelidade criativa ao Vaticano II, In: PASSOS e SOARES, Francisco: renasce a esperança, p.224. 
Deus manifesta-se no tempo e está presente nos processos da História. Isto faz privilegiar as ações que geram dinâmicas novas. E exige paciência e espera."294

Para Elias Royon, SJ, ex-provincial espanhol da Companhia de Jesus e expresidente da CONFER (Conferência Espanhola de Religiosos), Francisco, ao se exprimir assim, fala daquilo que mais caracteriza Santo Inácio e sua espiritualidade: a busca da vontade de Deus, que está significativamente manifestada em sua autobiografia, quando ele próprio se define como o “peregrino". Padre Jerônimo $\mathrm{Nadal}^{295}$, no prefácio deste relato, conta que quando Inácio se autodefine desta forma, quer mostra o sentido que dá às suas peregrinações: o de serem "o caminho pelo qual o Senhor o dirigiu, desde os primeiros dias de sua conversão" 296 .

$\mathrm{Na}$ visão de Royon, Francisco mantém em mente aquilo que mais caracteriza o peregrino. O papa fala da inquietação do coração e se pergunta: “o que Deus quer de mim?” Ao se questionar desta forma, Francisco é bem inaciano, porque neste questionamento se encontra significado o fim último do processo espiritual dos Exercícios, o fruto da longa formação do jesuíta para aprender a buscar e encontrar Deus em todas as coisas. Encontrar a vontade de Deus é o objetivo do instrumento tão inaciano que é o discernimento. ${ }^{297}$

No discurso que fez aos membros da comunidade da revista La Civiltà Cattolica, em 14 de junho de 2017, ele retorna ao tema:

Com inteligência humilde e aberta, "procurai e encontrai Deus em todas as coisas", como escrevia Santo Inácio. Deus age na vida de cada homem e na cultura: o Espírito sopra onde quer. Procurai descobrir o que Deus realizou e como continuará a sua obra. Um tesouro dos jesuítas é precisamente o discernimento espiritual, que procura reconhecer a presença do Espírito de Deus nas realidades humanas e culturais, a semente já plantada da presença nos acontecimentos, nas sensibilidades, nos desejos, nas tensões profundas dos corações e dos contextos sociais e espirituais. ${ }^{298}$

No discurso que fez na Plenária do Pontifício Conselho para a promoção da nova evangelização, Francisco afirmou:

294 SPADARO, Entrevista exclusiva do papa Francisco, p.27-8.

295 Natural de Palma de Maiorca, um dos primeiros companheiros de Inácio de Loyola.

296 SANTO INACIO. O relato do Peregrino, nota 5, p.37.

297 Disponível em: http://www.ihu.unisinos.br/78-noticias/560975-o-que-o-papa-francisco-ja-disseaos-jesuitas-artigo-de-elias-royon. Acesso em: 12 nov 2017.

298 Disponível em: http://w2.vatican.va/content/francesco/pt/speeches/2013/june/documents/papafrancesco_20130614_la-civilta-cattolica.html. Acesso em: 13 nov 2017. 
Cada batizado é "cristoforo", ou seja, portador de Cristo, como diziam os antigos Padres. Quem encontrou Cristo, como a Samaritana no poço, não pode conservar esta experiência para si, mas sente o desejo de a compartilhar, para levar outras pessoas a Jesus (cf. Jo 4). Todos nós devemos nos perguntar se quem se encontra conosco sente na nossa vida o entusiasmo da fé, se vê no rosto a alegria de ter encontrado Cristo. ${ }^{299}$

\title{
3.4
}

\section{Considerações finais do terceiro capítulo}

Na entrevista concedida à revista La Civiltà Cattolica, já mencionada, três meses após sua eleição, Francisco, retomando as palavras de Paulo VI, por ocasião da $32^{\mathrm{a}} \mathrm{CG}$, afirmou que o lugar dos jesuítas é a fronteira:

\begin{abstract}
O lugar que vos é próprio são as fronteiras. Este é o lugar dos jesuítas. Aquilo que Paulo VI, depois retomado por Bento XVI, disse sobre a Companhia de Jesus é valido de modo especial para vós, também hoje: "Onde quer que na Igreja, também nos campos mais difíceis e importantes, nas encruzilhadas das ideologias, nas trincheiras sociais, tenha existido e ainda exista o confronto entre as exigências urgentes do homem e a mensagem perene do Evangelho, ali estavam e ainda estão os jesuítas". Por favor, sede homens de fronteira, com aquela capacidade que deriva de Deus (cf. 2Cor3,6). Mas não deveis cair na tentação de domesticar as fronteiras: é preciso partir rumo às fronteiras, e não trazer as fronteiras para casa, para as envernizar um pouco e para as domesticar. ${ }^{300}$
\end{abstract}

Este comprometimento com as fronteiras, tão característico da Companhia de Jesus, na qual recebeu sua formação e desenvolveu sua espiritualidade, é facilmente detectável na linha eclesiológica que tenta imprimir em seu pontificado:

A Igreja é chamada a sair de si mesma e ir para as periferias, não apenas geográficas, mas também as periferias existenciais: as do mistério do pecado, da dor, das injustiças, das ignorâncias e recusa religiosa, do pensamento, de toda miséria. $^{301}$

Ao lutar por uma Igreja missionária, que escuta a sociedade, promove a liberdade cristã, se volta para os pobres e vive sua fé, Francisco está de olhos fixos nas fronteiras, tentando levar a elas a esperança cristã.

\footnotetext{
299 Disponível em: http://w2.vatican.va/content/francesco/pt/spches/2013/october/documentos/papa -francesco_20131014_plenaria-consiglio-nuova-evangelizzazione.html. Acesso em: 13 nov 2017. 300 Disponível em: http://w2.vatican.va/content/francesco/pt/speeches/2013/june/documents/papafrancesco_20130614_la-civilta-cattolica.html. Acesso em: 13 nov 2017.

301 Disponível em: http://w2.vatican.va/.../papa-francesco_20140823_messaggio-meeting-amiciziapopoli.html. Acesso em: 13 nov 2017.
} 
De acordo com John O’ Malley, quando Francisco exorta a Igreja a ir para as fronteiras e para as periferias, ele está simplesmente ecoando palavras de alguns dos mais recentes documentos jesuítas oficiais, incluindo os decretos das Congregações Gerais pós-conciliares. Logicamente, esta ideia não é monopólio dos jesuítas, mas não se pode esquecer que os jesuítas foram fundados como uma ordem missionária e esta nunca perdeu o impulso de sair para além do conhecido e confortável, seja literalmente por viagens ou metaforicamente através dos estudos acadêmicos. ${ }^{302}$

Francisco é especialmente comprometido com a fronteira dos refugiados e migrantes, tema importante também para a Companhia de Jesus. Já em 1980, por uma intuição do padre Arrupe, a Companhia fundou o Serviço Jesuíta aos Refugiados (JRS ou SJR), organização internacional com a missão de servir, acompanhar e defender pessoas refugiadas ou vítimas de deslocamento forçado. ${ }^{303}$ Com este novo serviço, ele forneceu uma atualização para a missão nesta fronteira. Na ocasião, Jorge Bergoglio era o Provincial da Argentina e foi responsável por inspirar seus companheiros jesuítas nesse sentido. ${ }^{304}$

Neste contexto, fica claro que a visita do Francisco aos refugiados africanos à ilha Italiana de Lampadusa, em julho de 2013, poucos meses após ter sido eleito papa, não foi um impulso casual. Quando lá clamou contra a "globalização da indiferença", estava colocando em ação o compromisso dos jesuítas de missão na fronteira do "serviço da fé e promoção da justiça", afirmado $32^{\mathrm{a}}$ Congregação Geral, em que Bergoglio esteve presente, e confirmado por todas as congregações subsequentes. Com certeza, esse compromisso teve um profundo efeito sobre ele e agora se faz sentir em seu pontificado. ${ }^{305} \mathrm{Na}$ ocasião, disse:

A cultura do bem-estar, que nos leva a pensar em nós mesmos, torna-nos insensíveis aos gritos dos outros, faz-nos viver como se fôssemos bolas de sabão: estas são bonitas mas não são nada, são pura ilusão do fútil, do provisório. Esta cultura do bem-estar leva à indiferença a respeito dos outros; antes, leva à globalização da indiferença. Neste mundo da globalização, caímos na globalização

302 Disponível em: http://www.ihu.unisinos.br/539064-papa-francisco-jesuíta-e-entao. Acesso em: 13 nov 2017.

303 BRAGA, Serviço Jesuíta a Migrantes e Refugiados: obra de misericórdia. Itaici: revista de espiritualidade inaciana, n.103, p.5-18.

304 Disponível em: www.ihu.unisinos.br/539064-papa-francisco-jesuíta-e-entao. Acesso em: 14 nov 2017.

305 Disponível em: www.ihu.unisinos.br/539064-papa-francisco-jesuíta-e-entao. Acesso em: 14 nov 2017. 
da indiferença. Habituamo-nos ao sofrimento do outro, não nos diz respeito, não nos interessa, não é responsabilidade nossa! ${ }^{306}$

Em novembro de 2013, já durante o pontificado de Francisco e após sua viagem a Lampaduza, foi instituída, pela Companhia de Jesus, a SJM (Serviço Jesuíta com Migrantes), para um trabalho específico com os migrantes. No Brasil, utiliza-se a sigla SJMR (Serviço Jesuíta a Migrantes e Refugiados) para acentuar o fato de que aqui se trabalha tanto com migrantes quanto com refugiados. $\mathrm{Na}$ América Latina e Caribe, é o SJM-LAC que congrega iniciativas de todas as províncias da região para a proteção de direitos humanos de refugiados, migrantes e outras vítimas do deslocamento forçado. ${ }^{307}$

\footnotetext{
306 Disponível em: http://www.ihu.unisinos.br/noticias/521786-qadao-onde-estas-caim-onde-esta-oteu-irmao-o-discurso-de-francisco-em-lampedusa. Acesso em: 14 nov 2017.

307 BRAGA, Serviço Jesuíta a Migrantes e Refugiados: obra de misericórdia. Itaici: revista de espiritualidade inaciana n.103, p.5-18.
} 


\section{A fronteira dos migrantes e refugiados e a Companhia de Jesus}

4.1

\section{A questão dos migrantes e refugiados}

A história da humanidade é uma história de migrações, ou seja, de grandes movimentos coordenados de pessoas entre os continentes. ${ }^{308}$ De acordo com o historiador Carlos Fouquet, ao ressaltar a importância da migração como fenômeno histórico que caracteriza o movimento dos homens em um contexto mundial desde os primórdios da civilização humana, "a história da humanidade é a história das migrações e de suas consequências"309. Assim sendo, para se compreender bem a história da humanidade, é necessário que se tenha em conta os processos migratórios que têm acompanhado a sua evolução desde o início. Como exemplo, podemos citar a chegada dos primeiros hominídeos à Europa, vindos da África, as ondas migratórias que mudaram a feição da Europa durante os primeiros séculos da civilização ocidental, a conquista das Américas e da África pela Europa, a emigração em massa japonesa após a Segunda Grande Guerra e, mais atualmente, a fuga de enormes contingentes de pessoas das guerras do Oriente Médio e do Norte da África.

De acordo como Giancarlo Pani, SJ, que é vice-diretor da La Civiltà Cattolica, os migrantes existem bem antes dos hominídeos, que apareceram há 120 mil anos, enquanto a primeira migração de que se tem registro remonta há 3,7 milhões de anos atrás, quando um macho, uma fêmea e o seu pequeno, depois de uma erupção vulcânica, deixaram a sua terra, na atual Tanzânia, buscando um outro lugar para habitar, já que lá não era mais possível viver. Esta primeira migração conhecida é atestada por pegadas da fuga dessa família, encontradas em Laoetoli, a 20 quilômetros do Vulcão Sadiman, impressas entre cinzas e lava. As pegadas desta família, de quem não se sabe mais nada, mas que adquiriu papel simbólico e universal para a história da humanidade, comprovam que o primeiro migrante nasceu muito antes do homem, que chegou à Europa somente há 40.000

\footnotetext{
308 Disponível em: http://www.alliancemagazine.org/feature/migration-the-oldest-and-still-best-toolin-the-anti-poverty-arsenal/ Acesso em: 20 jan 2018.

309 Disponível em: http://www.abep.org.br/publicacoes/index.php/anais/article/viewFile/1152/1115 Acesso em: 15 jan 2018.
} 
anos, vindo da África. ${ }^{310}$

Giancarlo Pani lembrou, em uma reflexão que fez durante as comemorações dos 37 anos de fundação do Serviço Jesuíta aos Refugiados, que até nos textos sagrados o papel dos migrantes é extremamente relevante. Para ele, a Bíblia é uma biblioteca escrita por migrantes e Abraão, um homem rico, embora não fosse um refugiado, fez-se migrante e Deus estreitou uma aliança com ele, definindo-o como "amigo". Lembrou também que esta aliança firmada com Deus continuou com Jacó, com José, com Moisés e com Israel, mostrando que Israel se torna povo de Deus como povo de refugiados, imigrantes fugindo da exploração, em busca de uma vida nova.

De acordo com Pani, os Patriarcas são descritos na Bíblia não como nômades e sim como imigrantes. Para tanto, cita alguns textos bíblicos, começando pelo livro do Êxodo, onde se lê: "Não oprima o imigrante: vocês conhecem a vida do imigrante, porque foram imigrantes no Egito", até chegar ao Levítico: "O imigrante será para vocês um concidadão: você o amará como a si mesmo, porque vocês foram imigrantes na terra do Egito"311.

O próprio Jesus, nascido como um sem-teto em Belém, filho de pais pobres, foi perseguido pelo rei Herodes e, por isso, com menos de dois anos, tornou-se refugiado no Egito, com seus pais. Quanto a isto, a Bíblia diz:

(...) eis que o Anjo do Senhor manifestou-se em sonho a José e lhe disse: "Levantase, toma o menino e sua mãe e foge para o Egito (...), porque Herodes procurará o menino para o matar". Ele se levantou, tomou o menino e sua mãe, durante a noite, e partiu para o Egito'. (Mt 2,12-13)

A denominação "refugiado" e seus direitos foram reconhecidos, em 1951, pela Convenção de Genebra, quando o mundo vivia as primeiras grandes mudanças estruturais e contabilizava as consequências de grandes conflitos. Hoje, mais de meio século depois, o número de refugiados cresceu proporcionalmente à população e reflete de maneira clara a crise dos tempos globais. Infelizmente,

310 Disponível em: http://www.ihu.unisinos.br/espiritualidade/comentario-do-evangelho/78-noticias/ 573763-a-atualidade-do-servico-jesuita-aos-refugiados-nos-37-anos-da-sua-fundacao.Acesso em: 12 dez 2017.

311 Cf. disponível em: http://www.ihu.unisinos.br/espiritualidade/comentario-do-evangelho/78noticias/573763-a-atualidade-do-servico-jesuita-aos-refugiados-nos-37-anos-da-sua-fundacao. Acesso em: 14 dez 2017. 
muitos dos países que assinaram a convenção para recebê-los não os querem mais. 312

Em 2000, a Assembleia Geral das Nações Unidas instituiu o Dia Mundial do Refugiado, que começou a ser celebrado em 2001. Com isto, a ONU pretendeu chamar a atenção do mundo para os problemas vividos por estes milhões de pessoas que são forçosamente obrigadas a deixar tudo para fugir de guerras, conflitos e perseguições, hoje majoritariamente provenientes da Síria, Afeganistão, Somália, Iraque e Sudão. ${ }^{313}$

Ultimamente, tem havido, no mundo, uma intensificação do processo migratório, desencadeado majoritariamente por motivos de guerras, perseguições políticas, étnicas, culturais, discriminação, busca de melhores condições de vida e também desastres ambientais. ${ }^{314}$

Hoje em dia, a crise política no Oriente Médio e no Norte da África e os conflitos daí derivados são os principais focos de origem de migrantes e refugiados, gerando milhões de desalojados no mundo. Para fugir de guerra e em busca de uma vida digna, estas pessoas vagueiam por países procurando algum que lhes dê refúgio. Seu destino preferido é a Europa.

Atravessar o Mediterrâneo é, hoje, a principal forma que os imigrantes e refugiados têm para alcançar a Europa e pedir asilo ou refúgio nos países da União Europeia. Segundo os dados do Alto Comissariado das Nações Unidas (ACNUR), são três as principais rotas migratórias que envolvem o Mediterrâneo. A primeira delas, e que recebe a menor quantidade de pessoas em comparação com as demais, é a rota do Mediterrâneo Ocidental ou Espanhola. Esse caminho tem início no Marrocos e termina na costa da Espanha. A quantidade de pessoas que se utilizam desta rota é menor do que a das duas outras. A segunda rota é a do Mediterrâneo Oriental ou Balcânica. Esse trajeto começa na Turquia e termina nas ilhas gregas, como a de Lesbos. Chegando em território europeu, os imigrantes costumam percorrer os países dos Bálcãs, como Hungria, Sérvia e Macedônia, até chegar a destinos pelos quais têm preferência, como Alemanha e Holanda. Por fim, a terceira e última rota migratória europeia é a do Mediterrâneo

\footnotetext{
312 Disponível em: http://www.ihuonline.unisinos.br/index.php?option=com_content\&view=article \&id $=3870 \&$ secao $=362$. Acesso em: 8 dez 2017.

313 Disponível em: http://agenciabrasil.ebc.com.br/internacional/noticia/2016-06/papa-franciscopede-que-pessoas-escutem-e-acolham-os-refugiados. Acesso em: 14 nov 2017.

314 Disponível em: http://mundoeducacao.bol.uol.com.br/geografia/migracao-internacional.htm Acesso em: 8 dez 2017.
} 
Central. Nela os imigrantes deixam a Líbia e atracam na costa italiana, principalmente em ilhas como a de Lampedusa. ${ }^{315}$

De acordo com Salil Shetty ${ }^{316}$, "somos testemunhas da pior crise de refugiados da nossa era, com milhões de homens, mulheres e crianças lutando para sobreviver a guerras brutais e redes de tráfico de pessoas, e governos que perseguem interesses políticos egoístas em vez de demonstrarem compaixão". 317

No relatório que apresentou em Beirute em junho de 2015, a Anistia Internacional acusou a comunidade internacional de um "fracasso vergonhoso" diante desta que é a pior crise de refugiados desde a Segunda Grande Guerra. Segundo esta ONG, esse fracasso tem condenado milhões de pessoas a um sofrimento insuportável e levado milhares à morte. Para Shetty, a crise dos refugiados é um dos maiores desafios do século 21, mas a resposta da comunidade internacional foi um fracasso vergonhoso. Aponta a necessidade de uma reforma radical de políticas e de práticas para criar uma estratégia mundial coerente. ${ }^{318}$

Alguns dados confirmam a preocupação do secretário-geral da Anistia Internacional. Pelo site da Organização Internacional para as Migrações (OIM ou IOM, em inglês), somente no Mediterrâneo, de $1^{\circ}$ de janeiro de 2016 a 3 de dezembro de 2017, chegaram à Europa, pelo mar, 515.655 pessoas, sendo que outras 7843 morreram ou desapareceram na tentativa de fazê-lo. ${ }^{319}$

É importante notar, no entanto, que a questão dos refugiados e migrantes é muito maior do que acontece no Mediterrâneo. Esta catástrofe humanitária faz suas vítimas por todo mundo e, em outras partes, não consegue a visibilidade dada ao tema na Europa. Milhares de pessoas, por exemplo, todos os anos, perdem suas vidas e são obrigados a suportar sofrimentos desumanos na travessia do deserto de Sonora, na fronteira sul dos Estados Unidos, na tentativa de buscar trabalho e uma

\footnotetext{
315 Disponível em: http://epocanegocios.globo.com/Mundo/noticia/2017/07/conheca-principaisrotas-migratorias-da-atualidade.html Acesso em: 8 nov 2017.

316 Secretário-geral da Anistia Internacional, ONG que defende os direitos humanos em nível internacional.

317 Disponível em: http://www.ufjf.br/ladem/2015/06/17/mundo-vive-maior-crise-de-refugiadosdesde-a-segunda-guerra-diz-anistia/. Acesso em: 7 dez 2017.

${ }^{318} \mathrm{Cf}$. disponível em: http://www.ufjf.br/ladem/2015/06/17/mundo-vive-maior-crise-de-refugiadosdesde-a-segunda-guerra-diz-anistia/. Acesso em: 7 dez 2017.

319 Cf. disponível em: https://www.iom.int/. Acesso em 7 dez 2017.
} 
vida melhor, fugindo da violência dos cartéis de droga, da pobreza opressiva e da injustiça econômica em seus países de origem. ${ }^{320}$

O deserto de Sonora, com $260.000 \mathrm{~km}^{2}$, é considerado o deserto mais quente da América do Norte e cobre grande parte do sudoeste dos Estados Unidos, no Arizona e na Califórnia, e do noroeste do México, em Sonora, Baja California e Baja California Sur. Toda a parte ocidental da fronteira dos Estados Unidos e México atravessa este deserto. De acordo com a Organização Internacional para as Migrações (OIM), esta fronteira é a mais mortífera do continente americano. Lá foram registradas 6.951 mortes entre 1998 e 2016. De acordo com dados do governo americano, cerca de 3 mil mortes aconteceram no estado do Arizona, principalmente no deserto de Sonora, um dos pontos de cruzamento mais perigosos. $^{321}$

Em 2016, a OIM contabilizou 700 migrantes mortos no continente a caminho dos Estados Unidos, sendo 75 na América Central e 400 na fronteira México-Estados Unidos. Estes números não incluem os desaparecidos contabilizados pelos comitês de familiares e que dão conta de 450 hondurenhos, 350 salvadorenhos e 80 guatemaltecos, segundo a ONG Fundación para la Justicia y el Estado Democrático de Derecho (FJEDD), do México.

O fenômeno dos desaparecimentos em massa no México está inserido no atual clima de guerra contra o tráfico de drogas e, de fato, na última década, o governo registrou o sumiço de 30 mil pessoas. Nesse número estão os próprios migrantes, especialmente vulneráveis às garras do tráfico. Na última década, observamos, no contexto da expansão do crime organizado no México, a criminalidade com foco nos migrantes. São alvos fáceis de simples identificação e que, em muitos casos, usam uma rota predeterminada. De acordo com Maureen Meyer, uma das diretoras da Wola, ONG que promove os direitos humanos no continente americano, esse problema já existe há muito tempo, embora agora esteja se tornando mais perceptível. ${ }^{322}$

Desde a posse de Donald Trump, em janeiro de 2017, houve também um grande aumento nas travessias irregulares da fronteira entre Canadá e Estados

\footnotetext{
320 Disponível em: http://www.ihu.unisinos.br/78-noticias/566289-andando-nas-pegadas-dosmigrantes. Acesso em: 23 jan 2018.

321 Disponível em: https://noticias.uol.com.br/ultimas-noticias/efe/2017/06/19/a-perigosa-tarefa-deatravessar-a-fronteira-mexico-eua.htm. Acesso em: 23 jan 2018.

322 Disponível em: https://noticias.uol.com.br/ultimas-noticias/efe/2017/06/19/a-perigosa-tarefa-deatravessar-a-fronteira-mexico-eua.htm. Acesso em: 23 jan 2018.
} 
Unidos. São pessoas evitando os postos de fronteira oficiais, de onde seriam devolvidos por causa de um acordo entre os dois países, tentando chegar a um lugar seguro por caminhos no meio da floresta, atravessando clareiras e fossos. Os riscos de uma travessia irregular são mais altos durante o inverno e há relatos de dedos congelados que precisam ser amputados na chegada ao Canadá. Desde então, as autoridades canadenses já interceptaram cerca de 17 mil migrantes de inúmeras nacionalidades, vindo dos EUA, além dos que atravessaram sem serem detectados. ${ }^{323}$

Segundo o relatório da ACNUR, em 2017, em todo o mundo, o deslocamento forçado causado por guerras, violência e perseguição atingiu, no ano de 2016, o número mais alto já registrado. No final de 2016, de acordo com este relatório, havia no mundo cerca de 65,6 milhões de pessoas que tinham sido forçadas a deixar seus locais de origem por diferentes tipos de conflitos, somando mais de 300 mil em relação ao ano anterior. Esse total aponta para a enorme quantidade de seres humano que precisam de proteção no mundo inteiro e evidenciam o imenso custo humano decorrente das guerras e perseguições em nível global: 65,6 milhões significam que, em média, 1 em cada 113 pessoas em todo mundo foi forçada a se deslocar - uma população maior que a do Reino Unido, o $21^{\circ}$ país mais populoso do mundo.

O mais preocupante é o fato das crianças representarem a metade desse total dos refugiados de todo o mundo, continuando a carregar um fardo desproporcional de sofrimento, principalmente devido à sua elevada vulnerabilidade. Tragicamente, 75 mil solicitações de refúgio foram feitas por crianças que viajavam sozinhas ou separadas de seus pais. O relatório aponta que possivelmente este número subestime a real situação real. ${ }^{324}$

\section{2 \\ O papa e os refugiados}

De acordo com Dom Claudio Hummes, "o vigor do pastoreio do papa Francisco se explica em grande parte por seu testemunho, suas atitudes, seus

\footnotetext{
323 Disponível em: https://theintercept.com/2017/11/27/haitianos-fogem-dos-eua-e-canada-seprepara-para-uma-nova-onda-de-refugiados/ Acesso em: 27 jan 2017.

324 Cf. disponível em: http://www.acnur.org/portugues/recursos/estatisticas/ Acesso em: $17 \mathrm{dez}$ 2017.
} 
gestos, que autenticam suas palavras e orientações"325. Comprovando as palavras de Dom Hummes, desde o início de seu pontificado, o papa tem dedicado atenção especial à questão dos migrantes e refugiados e dado testemunho constante de sua preocupação com o tema.

Diante das notícias de pequenos botes que naufragavam nas águas do Mediterrâneo, gerando centenas de mortes, principalmente de mulheres e crianças, em junho de 2013, o papa escolheu Lampedusa como primeira viagem apostólica do seu pontificado, para ver de mais perto a situação trágica em que estes seres humanos se encontravam. ${ }^{326}$ Esta viagem, tornou-se um marco norteador para seu pontificado: a tragédia dos migrantes e a indiferença do mundo. ${ }^{327}$

Lampedusa é uma pequena ilha italiana no Mediterrâneo, com pouco mais de $20 \mathrm{~km}^{2}$, entre a Sícilia e a costa da Líbia e da Tunísia, e uma das principais portas de entrada da União Europeia. Por suas belezas naturais, é destino de férias de muitos turistas e por sua proximidade da costa da África, a partir dos anos 1990, começou também a ser conhecida como o principal destino dos migrantes em fuga de guerras, perseguições e da miséria. ${ }^{328}$

Foi nesta época que Lampedusa entrou na rota da imigração clandestina. No início, eram somente pequenas embarcações que chegavam ao porto com cerca de dez pessoas. Sem qualquer estrutura oficial de acolhimento, os habitantes ajudavam os imigrantes como podiam e estes logo partiam em direção ao continente. No entanto, por volta de 2009, a onda imigratória começou a aumentar, alcançando seu auge em $2011^{329}$, quando já havia se tornado uma das principais rotas de refugiados do Norte da África em direção à Europa. A costa do Mediterrâneo nesta região, de acordo com a Revista IHU on line, é digna de uma versão contemporânea do Inferno de Dante. Nos poucos mais de cem quilômetros de mar que dividem a Europa do Norte da África já morreram milhares de pessoas, a maioria delas em função dos naufrágios das pequenas embarcações, mas também por fome e sede, enquanto ficavam à deriva no mar. ${ }^{330}$

\footnotetext{
325 HUMMES, As grandes metas do papa Francisco, p.11.

326 Cf. disponível em: http://www.ihu.unisinos.br/78-noticias/559581-novo-dicasterio-papa-seocupara-dos-migrantes. Acesso em: 7 dez 2017.

327 Cf. HUMMES, op. cit., p.12.

${ }^{328}$ Cf. disponível em: http://migramundo.com/lampedusa-a-porta-da-europa/. Acesso em: 8 dez 2017.

329 Cf. disponível em: https://oglobo.globo.com/mundo/lampedusa-uma-ilha-entre-extremos10532355. Acesso em: 8 dez 2017.

330 Disponível em: http://www.ihu.unisinos.br/171-noticias/noticias-2013/521701-papa-franciscovisita-lampedusa-o-inferno-no-mediterraneo. Acesso em 8 dez 2016.
} 
Nos últimos 20 anos, segundo dados do Ministério do Interior italiano e do ACNUR, mais de 300.000 pessoas chegaram à ilha. Até 1998, o principal porto de origem dos migrantes era o da Tunísia, mas, a partir de um acordo assinado, neste mesmo ano, entre Itália e Tunísia, limitando fortemente a emigração, as pessoas passaram a fugir da África pelo porto da Líbia.

No ano de 2011, Lampedusa acolheu cerca de 51.000 pessoas. Isto aconteceu depois de dois anos de redução drástica das chegadas, em que a migração diminuiu 90\%. A razão dessa diminuição foi um outro acordo, desta vez entre Itália e Líbia, pelo qual os migrantes era deportados antes de chegarem na costa italiana. Estas ações dos dois países provocaram uma condenação da Itália pelo Tribunal Europeu dos Direitos do Homem. Com o começo da chamada Primavera Árabe, logo no início de 2011, o número de refugiados que entravam na Europa por Lampadusa voltou a crescer. ${ }^{331}$

Naquela época, o Centro de Socorro e Primeiro Acolhimento (CPSA), que recebe os imigrantes assim que chegam à ilha, tinha capacidade para abrigar somente 850 pessoas e Lampedusa passou a receber, em média, 5 mil refugiados por mês. Em um certo ponto, o Estado parou de transferir os imigrantes para os centros do continente, sob a alegação que estavam lotados. Em setembro do mesmo ano, um grupo de tunisianos se revoltou e colocou fogo em dois pavilhões do centro de acolhimento, reduzindo sua capacidade para 250 pessoas. ${ }^{332}$ Dois anos depois, quando o papa chegou à ilha, o centro ainda não havia sido reconstruído e foi este cenário de calamidade que encontrou, o que fez com que Francisco se tornasse extremamente sensível ao tema.

Durante a visita a Lampedusa, Francisco manteve a sobriedade pedida pela situação em todas as cerimônias para "chorar" os mortos que ninguém chora, vítimas dos naufrágios de embarcações que transportavam imigrantes do Norte da África e Oriente Médio. Para tanto, acompanhado somente de seus secretários particulares, dos guarda-costas e do porta-voz do Vaticano, navegou em um barco que já havia socorrido 30 mil refugiados náufragos, percorrendo a costa até a Porta da Europa, monumento erguido em memória de todas as vítimas destes

${ }^{331}$ Cf. disponível em: http://migramundo.com/lampedusa-a-porta-da-europa/. Acesso em: 8 dez 2016.

332 Cf. disponível em: https://oglobo.globo.com/mundo/lampedusa-uma-ilha-entre-extremos10532355. Acesso em: 8 dez 2016. 
naufrágios. Antes de se recolher em oração, durante a travessia, lançou ao mar uma coroa de crisântemos brancos e amarelos, as cores do Vaticano. ${ }^{333}$

$\mathrm{Na}$ homilia da missa que celebrou com habitantes da ilha e refugiados, o papa agradeceu e encorajou a população a continuar a acolher os refugiados para dar exemplo ao mundo. Além disso, consolou e se solidarizou com migrantes, não deixando de denunciar e condenar a indiferença com que o mundo estava tratando esta tragédia. ${ }^{334}$ São suas as seguintes palavras:

Quem é o responsável pelo sangue destes irmãos e irmãs? Ninguém! Todos nós respondemos assim: não sou eu, não tenho nada a ver com isso; serão outros, eu não certamente. Mas Deus pergunta a cada um de nós: "Onde está o sangue do teu irmão que clama até mim?” Hoje ninguém no mundo se sente responsável por isso; perdemos o sentido da responsabilidade fraterna; caímos na atitude hipócrita do sacerdote e do levita de que falava Jesus na parábola do Bom Samaritano: ao vermos o irmão quase morto na beira da estrada, talvez pensemos "coitado" e prosseguimos o nosso caminho, não é dever nosso; e isto basta para nos tranquilizarmos, para sentirmos a consciência em ordem. A cultura do bem-estar, que nos leva a pensar em nós mesmos, torna-nos insensíveis aos gritos dos outros, (...) leva à indiferença a respeito dos outros; antes, leva à globalização da indiferença. Neste mundo da globalização, caímos na globalização da indiferença. Habituamo-nos ao sofrimento do outro, não nos diz respeito, não nos interessa, não é responsabilidade nossa! (...) Quem chorou pela morte destes irmãos e irmãs? Quem chorou por estas pessoas que vinham no barco? Pelas mães jovens que traziam os seus filhos? Por estes homens cujo desejo era conseguir qualquer coisa para sustentar as próprias famílias? Somos uma sociedade que esqueceu a experiência de chorar, de "padecer com": a globalização da indiferença tirou-nos a capacidade de chorar! $!^{335}$

A partir da ida a Lampedusa, o papa Francisco tornou-se um grande defensor dos migrantes e refugiados, insistindo sempre para que os países da Europa se abram e acolham estas pessoas. Sistematicamente retorna ao tema, insistindo que os países são pouco acolhedores, dando prioridade a seus próprios interesses, alegando problemas econômicos, sociais e de segurança. Ele repetidamente defende os direitos dos refugiados que, segundo ele, são inalienáveis. ${ }^{336}$

Entre muitas outras ocasiões nas quais trouxe à tona a crise dos refugiados e migrantes, em 25 de novembro de 2014, em visita ao Parlamento Europeu, que

\footnotetext{
333 Disponível em: https://www.publico.pt/2013/07/08/mundo/noticia/papa-francisco-escolhelampedusa-para-primeira-viagem-do-seu-pontificado-1599582. Acesso em: 8 dez 2016. 334 HUMMES, As grandes metas do papa Francisco, p.12-3.

335 Disponível em: http://w2.vatican.va/content/francesco/pt/homilies/2013/documents/papafrancesco_20130708_omelia-lampedusa.html. Acesso em: 19 dez 2017.

336 Cf. HUMMES, As grandes metas do papa Francisco, p.13.
} 
representa toda a União Europeia, voltou com ênfase ao tema, quando discursou acerca da dignidade humana:

É necessário enfrentar juntos a questão migratória. Não se pode tolerar que o Mar Mediterrâneo se torne um grande cemitério! Nos barcos que chegam diariamente às costas europeias, há homens e mulheres que precisam de acolhimento e ajuda. A falta de um apoio mútuo no seio da União Europeia arrisca-se a incentivar soluções particularistas para o problema, que não têm em conta a dignidade humana dos migrantes, promovendo o trabalho servil e contínuas tensões sociais. A Europa será capaz de enfrentar as problemáticas relacionadas com a imigração, se souber propor com clareza a sua identidade cultural e implementar legislações adequadas capazes de tutelar os direitos dos cidadãos europeus e, ao mesmo tempo, garantir o acolhimento dos imigrantes; se souber adoptar políticas justas, corajosas e concretas que ajudem os seus países de origem no desenvolvimento sociopolítico e na superação dos conflitos internos - a principal causa deste fenômeno - em vez das políticas interesseiras que aumentam e nutrem tais conflitos. É necessário agir sobre as causas e não apenas sobre os efeitos. ${ }^{337}$

Na mesma viagem, ao discursar no Conselho da Europa, disse:

De igual modo são numerosos os desafios do mundo contemporâneo que necessitam de estudo e de um empenhamento comum, a começar pelo acolhimento dos imigrantes, que precisam primariamente do essencial para viver, mas sobretudo que lhes seja reconhecida a sua dignidade de pessoas. Temos depois o grave problema do trabalho em toda a sua amplitude, especialmente pelos altos níveis de desemprego juvenil que se registam em muitos países - uma real hipoteca que grava sobre o futuro - mas também pela questão da dignidade do trabalho. ${ }^{338}$

Em abril de 2016, um mês depois da União Europeia fechar, devido ao aumento do número de imigrantes clandestinos, a rota de imigração que milhões de pessoas estavam usando para chegar à Europa fugindo dos conflitos na Síria, o papa Francico, em companhia do patriarca ecumênico de Constantinopla, Bartolomeu, e do arcebispo ortodoxo de Atenas, Hyeronimus, visitou a Ilha de Lesbos, na Grécia, para conhecer o Maria Refugee Camp. Lá, em função do que viu, convidou todas as paróquias a acolherem uma família de refugiados, e, dando ele mesmo o exemplo, levou para morar no Vaticano três famílias mulçumanas de refugiados escolhidas de forma aleatória, todas provenientes da Síria. $^{339} \mathrm{Na}$ viagem de volta, explicou que este foi um gesto humanitário, dentro a lei e às

\footnotetext{
337 Disponível em: https://w2.vatican.va/content/francesco/pt/speeches/2014/november/documents/ papa-francesco_20141125_strasburgo-parlamento-europeo.html. Acesso em: 3 dez 2017.

338 Disponível em: https://w2.vatican.va/content/francesco/pt/speeches/2014/november/documents/ papa-francesco_20141125_strasburgo-consiglio-europa.html. Acesso em: 3 dez 2017.

339 Cf. disponível em: http://www.ihu.unisinos.br/78-noticias/559581-novo-dicasterio-papa-seocupara-dos-migrantes Acesso em: 7 dez 2017.
} 
custas do Estado Pontifício, e que a ideia era ajudar estas pessoas a encontrar trabalho e uma nova vida na Europa. ${ }^{340}$

Em $1^{\circ}$ de janeiro de 2017 , o papa deu uma passo decisivo em direção a esta população quando criou um novo dicastério, chamado "Dicastério para o Serviço do Desenvolvimento Integral", presidido pelo Cardeal Peter Turkson, natural de Gana, e ex-presidente do Conselho Pontifício Justiça e Paz (CPJP). Este novo dicastério passou a responder pelos Pontificio Conselho de Justiça e Paz, Pontifício Conselho "Cor unum”, Pontifício Conselho para Pastoral dos Migrantes e Itinerantes e também pelo Pontifício Conselho para Pastoral no Campo da Saúde. ${ }^{341}$

O moto-próprio (decreto pessoal do papa) que instituiu este dicastério foi publicado em agosto de 2016, pela sala de imprensa da Santa Sé, juntamente com seu estatuto. ${ }^{342}$ Sobre o migrantes, afirma:

Portanto, a fim de implementar a solicitude da Santa Sé nos âmbitos mencionados, bem como com aqueles relacionados com a saúde e as obras de caridade, instituo o Dicastério para o Serviço do Desenvolvimento Humano Integral. Este Dicastério terá competências de modo particular nas áreas relacionadas com as migrações, com os necessitados, os enfermos e excluídos, os marginalizados e as vítimas dos conflitos armados e desastres naturais, os encarcerados, os desempregados e as vítimas de qualquer forma de escravidão e de tortura. ${ }^{343}$

Os documentos haviam sido aprovados pelo papa em 17 de agosto de 2016, acolhendo a proposta do Conselho de Cardeais (C9), composto com elementos dos cinco continentes, que aconselha o papa na renovação da Cúria Romana e no governo da Igreja Universal ${ }^{344}$. De acordo com o próprio Francisco, ao instituir este novo dicastério, sentiu necessidade de nele haver uma seção especial, momentaneamente sobre sua guia direta, "que expressasse a solicitude da Igreja para com os migrantes, os desalojados, os refugiados e as vítimas de tráfico humano"345.

\footnotetext{
${ }^{340} \mathrm{Cf}$. disponível em: http://g1.globo.com/jornal-nacional/noticia/2016/04/papa-leva-tres-familias-derefugiados-sirios-para-roma.html. Acesso em: 19 dez 2017.

${ }^{341} \mathrm{Cf}$. disponível em: https://w2.vatican.va/content/francesco/pt/motu_proprio/documents/papafrancesco-motu-proprio_20160817_humanam-progressionem.html. Acesso em: 7 dez 2017.

342 Cf. disponível em: http://www.agencia.ecclesia.pt/noticias/vaticano/vaticano-papa-criaestrutura-para-promover-desenvolvimento-humano-integral/. Acesso em: 7 nov 2017.

${ }_{343}$ Disponível em: http://w2.vatican.va/content/francesco/pt/motu_proprio/documents/papafrancesco-motu-proprio_20160817_humanam-progressionem.html. Acesso em 15 out 2017.

${ }^{344} \mathrm{Cf}$. disponível em: http://www.ihu.unisinos.br/78-noticias/559581-novo-dicasterio-papa-seocupara-dos-migrantes. Acessado em: 7 dez 2017.

${ }^{345}$ Disponível em: http://w2.vatican.va/content/francesco/pt/messages/migration/documents/papafrancesco_20170815_world-migrants-day-2018.html. Acesso em: 7 dez 2017.
} 
No parágrafo quarto do artigo primeiro do estatuto do dicastério, está especificada a inédita competência papal, sem precedentes na história recente da Santa Sé: "Uma seção do dicastério se ocupa especificamente do que concerne aos refugiados e migrantes. Esta seção é posta 'ad tempus' sob a condução do Sumo Pontífice, que a exerce nos modos que considerar oportunos". 346

Em fevereiro de 2017, por ocasião do VI Fórum de Migrações e Paz, promovido pelos padres scalabrianos, em Roma, que teve como tema "Integração e desenvolvimento: da reação à ação", o papa, mais uma vez, demonstrou com clareza seu interesse e comprometimento com a causa dos refugiados e migrantes. Em sua fala no discurso inicial, o papa aponta que a resposta diante da complexa realidade migratória atual deve ser resumida em quatro verbos: acolher, proteger, promover e integrar.

Para Maria Clara Bingemer, com estes quatro verbos, Francisco propõe "um itinerário feito de etapas possíveis e paradigmáticas que ajudem a ir marcando caminho" ${ }^{\$ 47}$ para que se possa enfrentar a problemática desta crise humanitária.

Segundo a teóloga, neste contexto, acolher significa não rejeitar o outro por considerá-lo uma ameaça, um inimigo. É necessário ultrapassar a indiferença e o medo com uma aproximação generosa de acolhida àquele que bate a nossa porta. O primeiro passo para tal é a oferta de abrigos dignos e decentes. Esta é a saída para humanizar e favorecer encontros pessoais que garantam a estas pessoas já tão sofridas uma relação humanizada e que gere humanização. ${ }^{348}$ Segundo o papa:

Há uma índole da rejeição que nos assemelha e que nos induz a olhar o próximo não como um irmão a acolher, mas como alguém deixado fora do nosso horizonte de vida pessoal, transformando-o antes num concorrente, num súdito a dominar. ${ }^{349}$

Perante esta índole da rejeição, em última análise enraizada no egoísmo e amplificada por demagogias populistas, é urgente uma mudança de atitude para

\footnotetext{
346 Cf. disponível em: http://www.ihu.unisinos.br/78-noticias/559581-novo-dicasterio-papa-seocupara-dos-migrantes. Acesso em: 7 dez 2017.

347 Cf. disponível em: http://www.celam.org/observatorio/docs/ANALISIS_COYUNTURA_Ma_Clara 170317. Acesso em: 7 dez 2017.

$\overline{3} 48 \mathrm{Cf}$. disponível em: http://www.celam.org/observatorio/docs/ANALISIS_COYUNTURA_Ma_Clara 170317.pdf. Acesso em: 7 dez 2017.

349 Discurso ao Corpo diplomático acreditado junto da Santa Sé, disponível em: w2.vatican.va/content/francesco/pt/speeches/2017/february/documents/papa-francesco_20170221 forum-migrazioni-pace.html . Acesso em: 7 nov 2017.
} 
superar a indiferença e antepor aos receios uma generosa atitude de hospitalidade em relação àqueles que batem às nossas portas. ${ }^{350}$

Proteção, no contexto da questão dos migrantes e refugiados, não se refere a qualquer forma de paternalismo e sim de defesa dos direitos e respeito à sua dignidade como ser humano. Quando o papa, em seu discurso, fala em proteção, ele traz à tona a consciência de que a experiência migratória é constitutivamente vulnerabilizante. Quem está em movimento, fora de seu habitat natural e suas referências, está muito mais exposto à exploração, abuso e violência, especialmente quando em situações irregulares ou quando se é vítima do tráfico humano. Para Francisco, a proteção destes grupos é um imperativo moral: 351

Proteger estes irmãos e irmãs é um imperativo moral que deve ser traduzido, adotando instrumentos jurídicos internacionais e nacionais, claros e pertinentes; fazendo escolhas políticas justas e clarividentes; preferindo processos construtivos, talvez mais lentos, à obtenção de consenso imediato; pondo em prática programas oportunos e humanizadores na luta contra os "traficantes de carne humana" que lucram com as desgraças dos outros; e coordenando os esforços de todos os protagonistas entre os quais, podeis estar certos disto, a Igreja estará sempre presente. ${ }^{352}$

Promover, aqui, se refere a dar a estas pessoas em situação de vulnerabilidade não só proteção, mas também trabalhar para que tenham acesso aos bens fundamentais que garantem vida plena. Esta promoção deveria começar pelas comunidades de origem, para que estas pessoas possam tanto optar por mudar como também por não migrar e continuar em sua terra. Já há desrespeito aos direitos de um ser humano quando este se vê obrigado a entrar nesta aventura migratória por não ter condições mínimas de uma vida digna. ${ }^{353}$ Segundo o papa:

É necessário promover o desenvolvimento humano integral de migrantes, refugiados e pessoas deslocadas, que "tem lugar mediante o cuidado dos bens incomensuráveis da justiça, da paz e da proteção da criação". Em conformidade com a doutrina social da Igreja, o desenvolvimento é um direito inegável de cada ser humano. Como tal, deve ser garantido, assegurando as condições necessárias para a sua prática, tanto na esfera individual como na social, conferindo a todos um acesso equitativo aos bens fundamentais e oferecendo a possibilidade de escolha e

\footnotetext{
350 Disponível em: http://w2.vatican.va/content/francesco/pt/speeches/2017/february/documents/ papa-francesco_20170221_forum-migrazioni-pace.html. Acesso em: 7 nov 2017.

351 Disponível em: http://www.celam.org/observatorio/docs/ANALISIS_COYUNTURA_Ma_Clara 170317.pdf. Acesso em: 7 dez 2017.

352 Disponível em: http://w2.vatican.va/content/francesco/pt/speeches/2017/february/documents/ papa-francesco_20170221_forum-migrazioni-pace.html . Acesso em 7 nov 2017.

353 Disponível em: http://www.celam.org/observatorio/docs/ANALISIS_COYUNTURA_Ma_Clara _170317.pdf. Acesso em 7 dez 2017.
} 
de crescimento. Também aqui, é necessária uma ação coordenada e prudente de todas as forças em jogo: da comunidade política à sociedade civil, das organizações internacionais às instituições religiosas. ${ }^{354}$

Finalmente, integrar é, neste sentido, reconhecer o valor e a riqueza da cultura do outro, favorecendo-lhe situações em que possa viver seus laços familiares. Integrar os diferentes e os diversos reflete a catolicidade da Igreja no que ela tem de mais central que é a universalidade. Assim agindo, a Igreja não só não anula a diversidade cultural e ética, como também cresce em sua vocação original. ${ }^{355}$ Quanto a isto, Francisco afirma:

A integração, que não é assimilação nem incorporação, constitui um processo bidirecional, que se baseia essencialmente no mútuo reconhecimento da riqueza cultural do outro: não se trata de nivelamento de uma cultura sobre a outra, nem sequer de isolamento recíproco, com o risco de "guetizações" nefastas e perigosas. No que se refere a quantos chegam e são chamados a não se fechar à cultura e às tradições do país anfitrião, respeitando antes de tudo as suas leis, não deve ser absolutamente ignorada a dimensão familiar do processo de integração. ${ }^{356}$

O papa, neste discurso, exortou todos a conjugarem estes quatro verbos tanto na primeira pessoa do singular quanto na primeira pessoa do plural. Para ele, este é um dever de cada um em particular e também da Igreja e da sociedade como um todo em relação àqueles em condição de migrantes ou refugiados: um dever de justiça, de civilização e de solidariedade. ${ }^{357}$ São dele as palavras:

Antes de tudo, um dever de justiça. Já não são sustentáveis as inaceitáveis desigualdades econômicas, que impedem que se ponham em prática o princípio do destino universal dos bens da terra. Todos nós somos chamados a empreender processos de partilha respeitadora, responsável e inspirada nos ditames da justiça distributiva. Por isso, é necessário encontrar o modo para que todos possam beneficiar dos frutos da terra, não só para evitar que se alargue o fosso entre aqueles que têm mais e os que devem contentar-se com as migalhas, mas também e sobretudo por uma exigência de justiça e equidade, e de respeito por cada ser humano (...) Em segundo lugar, há um dever de civilização. O nosso compromisso a favor dos migrantes, dos refugiados e das pessoas deslocadas é uma aplicação daqueles princípios e valores de acolhimento e fraternidade que constituem um patrimônio comum de humanidade e sabedoria no qual inspirar-se. (...) Finalmente, existe um dever de solidariedade. Diante das tragédias que "marcam a fogo" a vida de numerosos migrantes e refugiados — guerras, perseguições, abusos, violências e

\footnotetext{
354 Disponível em: http://w2.vatican.va/content/francesco/pt/speeches/2017/february/documents/ papa-francesco_20170221_forum-migrazioni-pace.html. Acesso em: 7 nov 2017.

${ }^{355} \mathrm{Cf}$. disponível em: http://www.celam.org/observatorio/docs/ANALISIS_COYUNTURA_Ma_Clara 170317.pdf. Acesso em: 7 nov 2017.

356 Disponível em: http://w2.vatican.va/content/francesco/pt/speeches/2017/february/documents/ papa-francesco_20170221_forum-migrazioni-pace.html. Acesso em: 7 nov 2017.

${ }^{357}$ Cf. disponível em: http://w2.vatican.va/content/francesco/pt/speeches/2017/february/documents/ papa-francesco_20170221_forum-migrazioni-pace.html. Acesso em: 7 nov 2017.
} 
mortes - não podem deixar de brotar espontaneamente sentimentos de empatia e de compaixão. "Onde está o teu irmão?" (cf. Gn 4, 9): esta pergunta, que desde as origens Deus dirige ao homem, interpela-nos hoje especialmente a respeito dos irmãos e das irmãs migrantes: "Esta não é uma pergunta feita a outrem; é uma pergunta posta a mim, a ti, a cada um de nós". A solidariedade nasce exatamente da capacidade de compreender as necessidades do irmão e da irmã em dificuldade, e de as assumir. ${ }^{358}$

Na mensagem para o Dia Internacional da Paz de 2018, celebrado no primeiro dia do ano, o papa retorna à questão do migrantes e refugiados, com o tema: "Migrantes e refugiados: homens e mulheres em busca da paz", e mais uma vez volta a propor o mesmo itinerário baseado nos verbos acolher, proteger, promover e integrar como quatro pistas de ação concreta em favor destes homens e mulheres em situação de risco absoluto: $:^{359}$

\begin{abstract}
Oferecer a requerentes de asilo, refugiados, migrantes e vítimas de tráfico humano uma possibilidade de encontrar aquela paz que andam à procura exige uma estratégia que combine quatro ações: acolher, proteger, promover e integrar. Acolher faz apelo à exigência de ampliar as possibilidades de entrada legal, de não repelir refugiados e migrantes para lugares onde os aguardam perseguições e violências, e de equilibrar a preocupação pela segurança nacional com a tutela dos direitos humanos fundamentais. (...) Proteger lembra o dever de reconhecer e tutelar a dignidade inviolável daqueles que fogem dum perigo real em busca de asilo e segurança, de impedir a sua exploração. Penso de modo particular nas mulheres e nas crianças que se encontram em situações onde estão mais expostas aos riscos e aos abusos que chegam até ao ponto de as tornar escravas. (...) Promover alude ao apoio para o desenvolvimento humano integral de migrantes e refugiados. Dentre os numerosos instrumentos que podem ajudar nesta tarefa, desejo sublinhar a importância de assegurar às crianças e aos jovens o acesso a todos os níveis de instrução: deste modo poderão não só cultivar e fazer frutificar as suas capacidades, mas estarão em melhores condições também para ir ao encontro dos outros, cultivando um espírito de diálogo e não de fechamento ou de conflito. (...) Por fim, integrar significa permitir que refugiados e migrantes participem plenamente na vida da sociedade que os acolhe, numa dinâmica de mútuo enriquecimento e fecunda colaboração na promoção do desenvolvimento humano integral das comunidades locais. ${ }^{360}$
\end{abstract}

Esta postura do papa Francisco, que é jesuíta, vai ao encontro da preocupação da Companhia de Jesus com a fronteira dos migrantes e refugiados e ao trabalho lá desenvolvido, através do SRJ - Serviço Jesuíta aos Refugiados -, organização internacional sob responsabilidade da Companhia, que há mais de 35 anos trabalha nesta frente. O JRS tem como missão "acompanhar, servir e

\footnotetext{
358 Disponível em: http://w2.vatican.va/content/francesco/pt/speeches/2017/february/documents/ papa-francesco_20170221_forum-migrazioni-pace.html. Acesso em: 7 nov 2017.

359 Disponível em: http://cnbbne2.org.br/papa-divulga-mensagem-para-o-dia-mundial-da-paz-2018/ Acesso em: 23 jan 2018.

${ }^{360}$ Cf. disponível em: https://w2.vatican.va/content/francesco/pt/messages/peace/documents/papafrancesco_20171113_messaggio-51giornatamondiale-pace2018.html Acesso em 7 nov 2017.
} 
defender" os refugiados, deslocados à força e todos os migrantes em situação de particular vulnerabilidade. Esta percepção do que seja a missão junto aos refugiados e migrantes é muito próxima da percepção de Francisco sobre o mesmo tema. Ambas encontram seus fundamentos no carisma inaciano e na compreensão de missão que a Companhia de Jesus desenvolveu através de suas seis últimas Congregações Gerais, que aconteceram já sob influência do Concílio Vaticano II.

\section{3 \\ A Companhia de Jesus e a fronteira dos migrantes e refugiados}

A Companhia de Jesus atua na fronteira dos migrantes e refugiados através do trabalho apostólico do Serviço Jesuíta aos Refugiados (SJR ou JRS - Jesuit Refugee Service, em inglês) fundado em 14 de novembro de 1980 por Pedro Arrupe SJ, então Provincial Geral dos jesuítas. ${ }^{361}$ A proposta de Arrupe, na época, era criar um serviço voltado para o humano, o educativo e o espiritual. Hoje, esses três princípios usados por Arrupe para descrever o tipo da atuação que ele esperava do SJR continuam a nortear os trabalhos e são sua base de crescimento e desenvolvimento como organização internacional pronta a enfrentar os conflitos e crises globais mais relevantes. ${ }^{362}$

\subsection{1 \\ Padre Pedro Arrupe SJ e o Serviço Jesuíta aos Refugiados}

Em 1980, a maioria dos refugiados era vietnamita, mas também havia, em menor número, alguns provenientes de outros países, tais como Etiópia, Somália, Camboja e Laos. ${ }^{363}$ No ano anterior, a situação destes refugiados que fugiam da ditadura comunista do Vietnam e do genocídio no Camboja e no Laos havia impressionado e comovido o padre Arrupe ${ }^{364}$. Estes homens e mulheres eram conhecidos como boat-people por usarem embarcações para fugir de seus países

\footnotetext{
361 Cf. disponível em: http://www.ihu.unisinos.br/78-noticias/561012-servico-jesuita-aos-refugiadosacompanhando-servindo-e-defendendo. Acesso em: $17 \mathrm{dez} 2017$.

362 Cf. BALLEIS, Um servicio humano, pedagógico y espiritual. Jesuitas: Anuario da la Compañia de Jesús, 2016. Curia Generalicia de Compañia de Jesús, Roma, p.12-5.

${ }^{363}$ Cf. disponível em: http://en.jrs.net/news_detail?TN=NEWS-20171113051504has. Acesso em: 7 nov 2017.

${ }^{364}$ Cf. BALLEIS, Um servicio humano, pedagógico y espiritual. Jesuitas: Anuario da la Compañia de Jesús, 2016. Curia Generalicia de Compañia de Jesús, Roma, p.12.
} 
de origem. Muito embora o termo seja normalmente usado em referência aos vietnamitas do Sul que fugiam da ditadura comunista, ele também se refere aos vietnamitas do Norte, com ascendência chinesa, que saíam do país em direção à Hong-Kong, fugindo da retaliação do governo de Hanói por questões étnicas. Estas pessoas, que pareciam encapsular todo o sofrimento gerado por uma guerra de 10 anos (1965-1975), haviam enfrentado o mar em barcos sem nenhuma condição para tal travessia, numa situação de enorme vulnerabilidade frente a ataques de piratas e às fortes tempestades do Mar do Sul da China e tinham, ainda, que encontrar países dispostos a acolhê-los. ${ }^{365}$

Depois do conflito com os Estados Unidos, o Vietnam se envolveu em confrontos locais com o Camboja e a China e, por isso, até 1978, era possível encontrar boat-people arriscando a vida na tentativa de encontrar uma nova situação menos sofrida, fugindo dos novos conflitos e também da perseguição política. $^{366}$

Arrupe proferiu as seguintes palavras, por ocasião da fundação do SJR:

Fiquei profundamente impressionado e comovido pelo sofrimento de milhares de fugitivos que chegavam por mar, além dos refugiados, e perguntei o que podia fazer a Companhia para aliviar, ao menos um pouco, a trágica situação. Principalmente porque a ajuda que se necessita não é apenas material: o que se espera sobretudo, da Companhia, é um serviço humano, coletivo e espiritual. ${ }^{367}$

No seu entender, o trabalho em prol dos refugiados tinha que ser uma prioridade para a Companhia. Ele estava convencido que os jesuítas, em concordância com a $31^{\mathrm{a}}$ e a $32^{\mathrm{a}} \mathrm{CGs}$ que destacavam a opção pelos pobres e pelos sem voz, deviam trabalhar para os mais pobres entre os mais pobres, em seguimento às palavras de Jesus Cristo ${ }^{368}$ :

Então dirá o rei aos que estiverem à sua direita: "Vinde benditos do meu Pai, recebei por herança o Reino preparado para vós desde a fundação do mundo. Pois tive fome e me deste de comer. Tive sede e me destes de beber. Era forasteiro e me acolheste. Estive nu e me vestiste, doente e me visitastes, preso e vieste ver-me". Então os justos lhe responderão: "Senhor, quando foi que te vimos com fome e te

365 Cf. GAVIN, P. Arrupe y la Fundación del Servício Jesuita a Refugiados. Jesuitas: Anuario da la Compañia de Jesús, 2016. Curia Generalicia de Compañia de Jesús, Roma, p.8.

366 Disponível em: https://www.historylearningsite.co.uk/vietnam-war/vietnamese-boat-people/. Acesso em: 27 nov 2017.

367 BALLEIS, op. cit., p.12 (a tradução é nossa).

${ }^{368}$ Cf. GAVIN, P. Arrupe y la Fundación del Servício Jesuita a Refugiados. Jesuitas: Anuario da la Compañia de Jesús, 2016. Curia Generalicia de Compañia de Jesús, Roma, p.8-9. 
alimentamos, com sede e lhe demos de beber? Quando foi que te vimos forasteiro e te recolhemos ou nu e te vestimos? Quando foi que te vimos doente e preso e fomos te ver?" Ao que responderá o rei: "Em verdade vos digo, cada vez que o fizestes a um desses meus irmãos mais pequeninos, a mim o fizeste". (Mt 25, 34-40)

Em carta escrita à Companhia universal por ocasião da fundação da SJR, padre Arrupe afirmou que a crise dos refugiados era um desafio que a Companhia não podia ignorar se pretendia continuar sendo fiel a convocação das recentes Congregações Gerais e aos critérios estabelecidos por Santo Inácio nas Constituições da Companhia de Jesus para o comprometimento com novas obras apostólicas: o maior bem universal, uma urgência cada vez maior, a dificuldade e complexidade do problema humano nelas implicado e a falta de outras pessoas comprometidas com a questão. ${ }^{369}$ Segundo Arrupe,

a escolha de um lugar ou outro será mais seguramente orientada, se se tiver diante dos olhos a regra do maior serviço divino e bem universal. Assim, na vinha imensa de Cristo Nosso Senhor, parece se deve escolher, em igualdade de circunstâncias, como em tudo o que segue se há de sempre entender, a região que mais necessitada estiver, quer pela falta de operários, quer pela miséria e fraqueza em que se encontra o próximo $(. . .)^{370}$

No final desta carta, afirma sua convicção de que a Companhia de Jesus, naquele momento, tinha condições privilegiadas para enfrentar tal desafio:

(...) esta situação constitui para a Companhia um desafio que não podemos ignorar se nos queremos manter fiéis aos critérios de Santo Inácio para o nosso trabalho apostólico e aos recentes apelos da $31^{\mathrm{a}}$ e $32^{\mathrm{a}}$ Congregações Gerais. Nas Constituições, Santo Inácio fala de um bem universal maior, de uma urgência crescente, da dificuldade e complexidade do problema humano envolvido, e da ausência de outras pessoas para atenderem a esta necessidade (cf Const VII, 2, n. 623). Com o nosso ideal de disponibilidade e universalidade, o número de instituições aos nossos cuidados e a colaboração ativa de muitos leigos que trabalham conosco, estamos particularmente bem preparados para ir ao encontro deste desafio e fornecer serviços que não estão a ser suficientemente desenvolvidos por outras organizações e grupos. Um incentivo adicional poderia ser o facto de o tipo de serviço requerido, porque pede períodos relativamente curtos de tempo aos jesuítas, não precisar, se bem planeado e coordenado, de interromper a vida e o progresso dos apostolados e instituições existentes. ${ }^{371}$

De acordo com K. Gavin, a data da fundação da SJR tinha um significado especial para o padre Arrupe. Além de seu próprio aniversário, era também o dia

${ }^{369} \mathrm{Cf}$. ibidem, p.9.

${ }^{370}$ Constituições da Companhia de Jesus e normas complementares, Sétima Parte, Cap. II, n.622D p.179.

${ }^{371}$ Disponível em: http://www.jrsportugal.pt/wp-content/uploads/pdf/carta-pedro-arrupe.pdf. Acesso em: 12 dez 2017. 
de São José Pignatelli, um ex-Superior Geral da Companhia, que também havia passado pela experiência de ser refugiado por ter dado apoio a vários jesuítas durante a supressão da Companhia, no final do século XVIII. ${ }^{372}$

José Pignatelli nasceu em Saragosa, na Espanha, e era descendente de família nobre. Tinha 40 anos e idade e 23 de Companhia de Jesus quando esta foi supressa, em 1773, pelo papa Clemente XIV, que cedeu às cortes maçônicas da Europa. Expulso da Espanha, viveu muitos anos em Bolonha, socorrendo e consolando os antigos jesuítas em suas penúrias e provações, mantendo sempre o espírito de jesuíta. Viveu o suficiente para ver a Ordem ser confirmada na Rússia e depois restaurada nas Sicílias. Nesta época reingressou na Companhia, trazendo consigo o espírito da antiga. Foi provincial e influenciou beneficamente as novas gerações. Enquanto Superior da Ordem, restaurou muitos colégios e despertou novas vocações. Morreu em 1811 sem ver a restauração completada, mas foi um laço de união entre a antiga e a nova Companhia. Foi canonizado em 1954 por Pio XII. ${ }^{373}$

Além do exemplo de São José de Pignatelli, a própria história pessoal de Arrupe estava ligada à fundação da SJR. Assim que ordenado padre jesuíta, foi enviado como missionário ao Japão. Em 1945, quando a bomba atômica destruiu a cidade de Hiroshima, Arrupe lá vivia e era o mestre dos noviços. Como havia estudado medicina, pode atender muitas vítimas desta enorme tragédia humana. Desta experiência lhe ficou a solidariedade para com as vítimas inocentes das guerras. $^{374}$

Em um dos últimos discursos que fez a um grupo de jesuítas que trabalhavam com refugiados, na Tailândia, pouco antes de sofrer um derrame cerebral, padre Arrupe estabeleceu um paralelo inquietante entre a situação dos refugiados vietnamitas e a devastação humana de Hiroshima. Para ele, a explosão da bomba atômica no Japão e os sofrimentos dos povos vietnamitas, obrigados a deixarem suas terras, não eram somente uma tragédia por conta das vidas humanas destruídas, mas também um crime horrível contra a humanidade. ${ }^{375}$ Diante desta constatação, Arrupe deu-se conta da dimensão do trágico êxodo dos

${ }^{372} \mathrm{Cf}$. GAVIN, P. Arrupe y la Fundación del Servício Jesuita a Refugiados. Jesuitas: Anuario da la Compañia de Jesús, 2016. Curia Generalicia de Compañia de Jesús, Roma, p.9.

373 Disponível em: http://www.taici.org.br/santos-da-companhia-de-jesus/27/14-11-sao-josepignatelli-1737-1811. Acesso em: 12 dez 2017.

${ }_{374} \mathrm{Cf}$. GAVIN, P. Arrupe y la Fundación del Servício Jesuita a Refugiados. Jesuitas: Anuario da la Compañia de Jesús, 2016. Curia Generalicia de Compañia de Jesús, Roma, p.9.

$375 \mathrm{Cf}$. ibidem, loc. cit. 
refugiados e quis que os jesuítas enfrentassem o desafio de ir ao encontro das necessidades humanas e espirituais destas pessoas. ${ }^{376}$ Desta constatação nasceu o SJR.

Em 1980, por ocasião da fundação do SJR, já haviam aproximadamente 8,5 milhões de refugiados espalhados pelo mundo. De acordo com o relatório divulgado pela ACNUR, em 2017, a situação é muito mais dramática e este número cresceu para mais de 22,5 milhões de pessoas, o mais alto de todos os tempos, sem contar os 65,5 milhões de migrantes internos que são obrigados a deixar seu lugar de origem. ${ }^{377}$

Entretanto, apesar destes números alarmantes, a solidariedade global para com estas pessoas tem diminuído vertiginosamente. Em 1980, por exemplo, os Estados Unidos deram asilo a mais de 207.000 refugiados, enquanto que, em 2017, somente cerca de 53.000 foram reassentados no país. Enquanto isto, do outro lado do Atlântico, mesmo diante desta situação calamitosa, a Europa vem, via de regra, fechando sistematicamente suas portas a migrantes e refugiados. ${ }^{378}$

Nos anos 80, o contexto da política global estava definido pela separação entre Oriente e Ocidente, entre o comunismo e o capitalismo. As guerras do Vietnam e do Camboja aconteceram em meio a uma grande divisão ideológica na região da Ásia voltada para o Pacífico. Como consequência destes conflitos, a crise dos refugiados oriundos desta área passou a ser uma parte central da política mundial.

O SJR surgiu neste contexto e começou como uma iniciativa humilde de uns poucos jesuítas e leigos que trabalhavam perto de campos de refugiados e ofereciam serviços pastorais e educativos. De acordo com Thomas Smolich ${ }^{379}$, Arrupe não teve, nesta época, nenhuma grande ideia sobre como trabalhar com os refugiados e se limitava a caminhar com estas pessoas e ver o que acontecia. No entanto, em pouco tempo, os jesuítas e colaboradores envolvidos no serviço já

\footnotetext{
376 Disponível em: http://www.mariaservadatrindade.com.br/site/index.php/not\%C3\%ADcias/483audi\%C3\%AAncia-papal-ao-servi\%C3\%A7o-dos-jesu\%C3\%ADtas-para-refugiados.html. Acesso em: 24 dez 2017.

377 Cf. disponível em: http://www.acnur.org/portugues/recursos/estatisticas/. Acesso em: 17 dez 2017.

${ }^{378}$ Cf. disponível em: http://en.jrs.net/news_detail?TN=NEWS-20171113051504has. Acesso em: 7 nov 2017.

379 Diretor Internacional do Serviço Jesuíta aos Refugiados, desde outubro de 2015.
} 
estavam formando pessoas e preparando-as para a realocação, muitas vezes em países de língua inglesa como Estados Unidos, Canadá e Austrália. ${ }^{380}$

Diante da expansão do SJR poucos anos após sua fundação, a necessidade de um espaço que possibilitasse a coordenação dos projetos e da estruturação do serviço se fez sentir e foi então criado um escritório regional em Bangkok com este fim. Concomitantemente, nesta mesma época, surgiram outras iniciativas da SJR na América Central e no Sudão, supervisionadas diretamente pelo escritório internacional com sede na Cúria da Companhia de Jesus em Roma.

Na década de 90, com a queda do muro de Berlim, houve no mundo uma onda de esperança de um futuro melhor através de acordos de desarmamento, de paz e também de ajuda para o desenvolvimento de regiões em necessidade. Embora alguns conflitos tenham realmente se resolvido, esta esperança não se concretizou e outros conflitos igualmente terríveis surgiram, entre eles, a guerra entre as etnias da ex-Iugoslávia e o massacre de Ruanda em 1994. Na tragédia humanitária que envolveu todos os países situados na região dos Grandes Lagos, como Ruanda, Burundi e Zaire, vários milhões de pessoas morreram diretamente em consequência da guerra. Os motivos ideológicos da década anterior foram substituídos por divisões de identidade étnica.

Nesta época, o SRJ se estabeleceu definitivamente na África, trabalhando com refugiados de Ruanda, Burundi e Congo que chegavam a Zâmbia, Angola, Malwi, Zimbábue e África do Sul, se somando aos refugiados da guerra do Sudão. Em um curto período de tempo, a África se tornou o principal foco de trabalho do SJR.

Em 2002, o SJR passou também a trabalhar com refugiados que chegavam à África Ocidental devido aos conflitos na Libéria, Serra Leoa e Guiné. Neste momento, o organização já tinha quatro regiões de atuação neste continente que representavam mais da metade do investimento financeiro, de trabalho e de pessoal da entidade.

Durante a década de 1990, a SJR também abriu outras frentes de trabalho em outras partes do mundo, entre elas o Sul da Ásia, Norte do Sri Lanka, no sul da Índia, na América Latina, no México e nos Bálcãs.

${ }^{380}$ Cf. disponível em: http://www.ihu.unisinos.br/78-noticias/561012-servico-jesuita-aos-refugiadosacompanhando-servindo-e-defendendo. Acesso em: 17 dez 2017. 
Durante a gestão do padre Kolvenbach como Superior Geral, o Serviço Jesuíta aos Refugiados se desenvolveu muito e conseguiu o status de Organização Internacional não-Governamental (ONG).

Embora a crise de refugiados já existisse há décadas na Palestina, a atuação da SJR nesta região é bem recente. Por ser uma instituição cristã, encontrou muita resistência para penetrar em países onde dominava o Islã. Com a guerra no Iraque, em 2005, entre sumitas e xiitas, que quase destruiu o país, levando milhões de pessoas a fugir buscando asilo em outros países, Adolfo Nicolás, recém-eleito Provincial Geral da Companhia de Jesus, instou a SJR a trabalhar com os iraquianos no Oriente Médio. Poucos anos depois, já havia projetos da SJR na Síria, Jordânia e Turquia e também no Norte da África.

A Primavera Árabe de 2011 e 2012 mudou completamente a situação do Norte da África e do Oriente Médio. As aspirações democráticas na Síria, por exemplo, se converteram em um banho de sangue, gerando, até 2016, mais de 200.000 vítimas, três milhões de refugiados e seis milhões de desalojados internos. Em meio a esta crise, que pode até ser considerada a pior crise humanitária da história desde a $2^{\mathrm{a}}$ Grande Guerra, o SJR se fixou definitivamente neste país, se expandindo com o tempo ao Líbano, Jordânia, Turquia e norte do Iraque. Hoje, o trabalho que desenvolve no Oriente Médio supera, em tudo, o realizado em todas as regiões de ação da África. ${ }^{381}$

\subsection{2 \\ O Serviço Jesuíta aos Refugiados hoje}

Atualmente, os conflitos mundiais estão determinados por divisões religiosas, pelo extremismo islâmico e pela guerra contra o terrorismo. A luta pela identidade religiosa substituiu as guerras de motivação política da década de 1980 e as lutas étnicas da década seguinte. Atualmente, um terço de todos os refugiados com quem o SJR trabalha são mulçumanos.

A experiência dos últimos anos mostrou que o SJR, como organização baseada na fé, pode trabalhar no Oriente Médio, na Ásia Central, incluindo o Afeganistão. O fato de haver muitos mulçumanos entre os colaboradores do SJR é

381 Cf. BALLEIS, Um servicio humano, pedagógico y espiritual. Jesuitas: Anuario da la Compañia de Jesús, 2016. Curia Generalicia de Compañia de Jesús, Roma, p.12-5. 
um sinal que, mesmo em época de extremismo religioso, é possível trabalhar e viver juntos, através do diálogo inter-religioso, através do respeito às tradições religiosas alheias e da noção de hospitalidade, profundamente arraigadas tanto nas tradições cristãs, como nas judias e nas islâmicas. ${ }^{382}$

Narrando sua experiência na SRJ de Aleppo, na Síria, Mourad Abu-Seif, SJ, deixa clara esta possibilidade de diálogo inter-religioso promovido pela organização:

Pessoalmente, jamais, antes da crise, tinha me ocorrido a possibilidade de construir com meus Irmãos e Irmãs mulçumanos, relações como as que temos, hoje, graças ao trabalho comum. Jamais teria imaginado que, um dia, celebraria a missa na capela de nossa residência, enquanto na sala ao lado, uma jovem mulçumana estendia seu pequeno tapete para orar, o que, por vezes, fazia até mesmo dentro da própria capela. Nunca teria sonhado que me sentiria em casa, em uma Mesquita, acolhido pelos meus Irmãos, em Alepo.

Nosso trabalho e nossa relação pelo bem comum se tornaram motivo de um encontro, no qual já não há mais lugar para preconceitos e muito menos para segregar as pessoas. Muitos dos que viveram esta experiência continuam na Síria, trabalhando em silêncio. Não são extremistas e nem terroristas. São a esperança da Síria. O trabalho em comum os guiou para a reconciliação antecipada que a Síria deseja alcançar. Mas também colocam suas esperanças no apoio do mundo todo, para poderem seguir sendo a levedura desta sociedade em prol de um futuro melhor. ${ }^{383}$

Hoje, a SJR trabalha em cerca de 50 países, servindo em torno de um milhão de refugiados e migrantes internos, $55 \%$ dos quais são mulçumanos ${ }^{384}$, fazendo a Companhia de Jesus presente nas áreas de conflito mais difíceis, tais como Síria, Afeganistão, República Centro-africana, Sudão do Sul e República Democrática do Congo. ${ }^{385}$ Conta com uma equipe de trabalho de 1800 pessoas, entre elas uns 70 jesuítas e 50 religiosas e um orçamento aproximado de 50 milhões de dólares para atender as necessidades dos refugiados nas áreas da educação, alimentação e apoio psicossocial. Estas cifras são bem modestas, se comparadas aos números do Catholic Relief Services, da Caritas Internacional, do Médicos Sem Fronteiras e do ACNUR, que também trabalham com refugiados. ${ }^{386}$

382 Cf. BALLEIS, Um servicio humano, pedagógico y espiritual. Jesuitas: Anuario da la Compañia de Jesús, 2016. Curia Generalicia de Compañia de Jesús, Roma, p.12-5.

383 ABU-SEIF, Dialogo interreligioso: esperanza y miedo. Jesuitas: Anuario da la Compañia de Jesús, 2016. Curia Generalicia de Compañia de Jesús, Roma, p.41 (a tradução é nossa).

${ }^{384} \mathrm{Cf}$. disponível em: http://www.ihu.unisinos.br/78-noticias/561012-servico-jesuita-aos-refugiadosacompanhando-servindo-e-defendendo. Acesso em: 17 dez 2017.

385 Cf. BALLEIS, Um servicio humano, pedagógico y espiritual. Jesuitas: Anuario da la Compañia de Jesús, 2016. Curia Generalicia de Compañia de Jesús, Roma, p.12-5.

${ }^{386} \mathrm{Cf}$. disponível em: http://www.ihu.unisinos.br/78-noticias/561012-servico-jesuita-aos-refugiadosacompanhando-servindo-e-defendendo. Acesso em: 17 dez 2017. 
Embora sua voz seja escutada por embaixadas e políticos, a SJR não se compromete com nenhuma agenda política. Assim sendo, sua autoridade para defender os direitos dos refugiados provém unicamente da sua capacidade de dar voz aos migrantes, ajudando-os a defender suas causas em nível local, regional e internacional.

A SJR está enraizada nos valores cristãos e também em valores e princípios humanitários, chegando a todos que necessitam, independente de sua origem étnica, política ou religiosa. Atualmente é uma das principais obras da Companhia de Jesus em áreas principalmente mulçumanas e trabalha com mulçumanos para ajudar outros mulçumanos em dificuldade, reconhecendo as profundas necessidades religiosas das pessoas a quem serve. ${ }^{387}$

Um dos focos de ação mais importantes da SJR é a educação. Seus projetos educativos seguem a mesma tradição neste campo que tem caracterizado o ministério da Companhia de Jesus ao longo de sua existência. A possibilidade de servir a pessoas marginalizadas pela sociedade oferecendo uma educação de qualidade é uma maneira de, hoje, atualizar concretamente o serviço da fé e promoção da justiça nos lugares onde haja maior necessidade, como têm preconizado as cinco últimas Congregações Gerais da Companhia de Jesus.

Ao investir na educação desde a pré-escola até o ensino superior, o SJR busca avivar a confiança dos jovens, com a intenção de formar futuros líderes, animando-os a crescerem e se desenvolverem, acreditando em si próprios e em sua capacidade. Também quer chegar àqueles mais desfavorecidos que, de outra forma, não teriam acesso à educação. ${ }^{388}$

O jesuíta Stan Fernandes, que trabalhou na SJR de Kabul, no Afeganistão, e vivenciou o sequestro do padre Alexis Premkumar SJ, pelo Talibã, e a suspensão por um mês dos serviços oferecidos a crianças e jovens afegãos, por questões de segurança em função do fato ocorrido com o jesuíta, conta porque a SJR reassumiu seus trabalhos, mesmo depois da situação vivida por padre Alexis:

Quando Prem foi sequestrado, suspendemos nossos projetos no Afeganistão durante um mês. Porém, mais tarde, os retomamos, conscientes da quantidade de

387 Cf. BALLEIS, op. cit., p.12.

${ }^{388}$ Cf. FERNANDES, Avivar la confianza mediante la educación. Jesuitas: Anuario da la Compañia de Jesús, Roma, p.26-27. 
crianças afegãs que se apegam às esperanças que os referidos projetos lhes oferecem. ${ }^{389}$

Outro foco de ação muito importante para o SJR é o acompanhamento psicológico, que, de acordo com Thomas Smolich SJ, é basicamente acompanhar as pessoas, indo à casa delas, buscando conhecer suas histórias, ouvi-las e, às vezes, criar oportunidades de reuni-las para que possam compartilhar histórias. Quando o grupo é formado por católicos, pode-se também dar ao encontro uma dimensão explicitamente religiosa. Através destes grupos é possível ajudar os refugiados a lidarem com o trauma que vivenciaram para que possam ter melhores condições de fazer a transição para o próximo estágio de suas vidas. ${ }^{390}$ De acordo com o jesuíta:

Todos nós nos sentimos melhor se tivermos um lugar onde podemos falar com alguém sobre o que nos aconteceu. Nunca esquecemos as dificuldade, mas quanto mais lidarmos com elas, maior é a chance de sucesso. ${ }^{391}$

Este acompanhamento é, inclusive, um traço característico do SJR, seguindo a intuição inicial de Arrupe, que contava: "Mesmo quando estamos distribuindo alimentos, sempre há um pouco de acompanhamento, de caminhar com as pessoas e aprender sobre a vida delas" 392 . O acompanhamento que tem, ao longo dos anos, sido a pedra angular desta organização é uma palavra com muitos significados, mas, na realidade, poucos penetram o sentido que foi bem explicitado, em 1985, no pronunciamento feito na primeira reunião dos diretores da SJR, em Chiang Mai, na Tailândia:

Ao mesmo tempo em que estamos sempre dispostos a ajudar os refugiados em suas necessidades materiais e espirituais, além de elaborar projetos que os conduzam a uma vida mais plena e mais independente, também colocamos especial ênfase em "estar com" mais do que "fazer por". Queremos que nossa presença entre os refugiados seja a de compartilhar com eles, de os acompanhar, a de andar pelo mesmo caminho. E, na medida do possível, queremos sentir o que eles têm

\footnotetext{
389 FERNANDES, Avivar la confianza mediante la educación. Jesuitas: Anuario da la Compañia de Jesús, Roma, p.27.

${ }^{390} \mathrm{Cf}$. disponível em: http://www.ihu.unisinos.br/78-noticias/561012-servico-jesuita-aos-refugiadosacompanhando-servindo-e-defendendo. Acesso em: $17 \mathrm{dez} 2017$.

391 Disponível em: http://www.ihu.unisinos.br/78-noticias/561012-servico-jesuita-aos-refugiadosacompanhando-servindo-e-defendendo. Acesso em: 17 dez 2017.

392 Cf. disponível em: http://www.ihu.unisinos.br/78-noticias/561012-servico-jesuita-aos-refugiadosacompanhando-servindo-e-defendendo. Acesso em: 17 dez 2017.
} 
sentido, sofrer como eles e compartilhar suas mesmas esperanças e aspirações, ver o mundo através de seus olhos. ${ }^{393}$

Mais tarde, o SJR abraçou o conceito de "estar com" como um dos elementos chaves de sua missão, que são acompanhar, servir e defender. ${ }^{394}$

Em setembro de 2013, quando visitou o Centro Astalli, o papa Francisco, seguindo seu carisma inaciano, depois de saudar os presentes, principalmente os refugiados, resumiu o que ele entende por estas três palavras-chave. Ressaltou que "servir é acolher a pessoa que chega com atenção, curvando-se sobre quem tem necessidade, estendendo-lhe a mão, sem cálculos, sem temor, com ternura e compreensão, como Jesus inclinou-se e lavou os pés dos apóstolos”. Servir é também "trabalhar ao lado dos mais necessitados, estabelecer com eles relações de humanas de proximidade, vínculos de solidariedade"395; significa "reconhecer e acolher os pedidos de justiça, de esperança e procurar juntos caminhos, percursos justos de libertação" ${ }^{\text {396. }}$.

Em relação a "acompanhar", Francisco destacou a evolução do caminho do Centro, que passou de uma primeira acolhida ao acompanhamento das pessoas e à sua inserção social:

Não basta o pão se não vem acompanhado da possibilidade de aprender a caminhar com as próprias pernas. A caridade que deixa o pobre assim como é não é suficiente. A misericórdia verdadeira, aquela que Deus nos dá e ensina, pede justiça, pede que o pobre encontre o caminho para não ser como tal"397.

Afirmou ainda que "ninguém mais deve ter necessidade de uma refeição, de um alojamento por sorte, de um serviço de assistência legal para ter reconhecido o próprio direito de viver e trabalhar e ser uma pessoa em plenitude." 398

Por último, Francisco disse que servir e acompanhar também quer dizer defender. Defender é ficar ao lado do mais frágil. É “dar voz à voz de quem sofreu

\footnotetext{
393 VELLA, El acompanamiento como piedra angular. Jesuitas: Anuario da la Compañia de Jesús, Roma, p. 16-7.

394 Ibidem, p.17.

395 Disponível em: https://w2.vatican.va/content/francesco/pt/speeches/2013/september/documents /papa-francesco_20130910_centro-astalli.html. Acesso em: 18 dez 2017.

${ }_{396}$ Disponível em: https://w2.vatican.va/content/francesco/pt/speeches/2013/september/documents /papa-francesco_20130910_centro-astalli.html. Acesso em: 18 dez 2017.

397 Disponível em: https://w2.vatican.va/content/francesco/pt/speeches/2013/september/documents /papa-francesco_20130910_centro-astalli.html. Acesso em: 18 dez 2017.

398 Disponível em: https://w2.vatican.va/content/francesco/pt/speeches/2013/september/documents /papa-francesco_20130910_centro-astalli.html. Acesso em: 18 dez 2017.
} 
e sofre, de quem teve seus direitos espezinhados, de quem viveu tanta violência que sufocou até o desejo de obter justiça"399.

\subsection{3 \\ As Congregações Gerais e a SJR}

Imaginar que a fundação do SJR seja simplesmente consequência de uma crise humanitária significativa é uma posição por demais simplista. Este serviço se coloca num contexto muito mais amplo de um projeto de Pedro Arrupe, de adaptar a Companhia à proposta de aggiornamento do Concílio Vaticano $\mathrm{II}^{400}$ que buscava a atualização da mensagem da salvação, procurando exprimi-la para o mundo moderno. ${ }^{401}$

A SJR nasceu, assim, através da percepção de Arrupe, como fruto da tomada de consciência da Igreja e da Companhia, na figura de seu Superior Geral, dos sinais dos tempos e da exigência da missão naquele momento histórico.

Foi padre Arrupe que, em 1974, como Provincial Geral, convocou e presidiu a $32^{\mathrm{a}}$ Congregação Geral da Companhia, que acabou se tornando um marco fundamental na história dos jesuítas, sobretudo pela proclamação que a fé em Deus precisa ser decisivamente unida à luta infatigável para abolir todas as injustiças que pesam sobre a humanidade. ${ }^{402}$

Michael Campbell-Johnston, SJ, que trabalhou com Arrupe na fundação da SJR, conta que ele, durante a congregação, reconheceu que sua maior tarefa seria ajudar os jesuítas do mundo inteiro a se renovar, segundo a visão do Concílio. ${ }^{403}$ Esta redefinição dos objetivos da Companhia está bem demonstrada no Decreto IV desta mesma congregação que diz:

A missão da Companhia de Jesus, hoje, é o serviço da fé, do qual a promoção da justiça constitui uma exigência absoluta enquanto faz parte da reconciliação dos homens, exigida pela reconciliação dos mesmos com Deus. Foi sempre missão da Companhia, embora em modalidades diferentes, mas hoje reveste sentido novo e

\footnotetext{
399 Disponível em: https://w2.vatican.va/content/francesco/pt/speeches/2013/september/documents /papa-francesco_20130910_centro-astalli.html. Acesso em: 18 dez 2017.

400 Cf. GAVIN, P. Arrupe y la Fundación del Servício Jesuita a Refugiados. Jesuitas: Anuario da la Compañia de Jesús, 2016. Curia Generalicia de Compañia de Jesús, Roma, p.10.

401 Cf. disponível em: http://faje.edu.br/periodicos/index.php/perspectiva/article/view/270/504 Acesso em: 23 dez 2017.

402 Cf. disponível em: http://www.ihu.unisinos.br/78-noticias/551413-pedro-arrupe-cronologia-deum-profeta. Acesso em: 20 jan 2018.

${ }^{403} \mathrm{Cf}$. GAVIN, P. Arrupe y la Fundación del Servício Jesuita a Refugiados. Jesuitas: Anuario da la Compañia de Jesús, 2016. Curia Generalicia de Compañia de Jesús, Roma, p.10.
} 
urgência muito especial, devido às necessidades e aspirações dos homens do nosso tempo. Efetivamente, encontramo-nos em presença de uma série de novos desafios. ${ }^{404}$

De acordo com este mesmo Decreto 4, na introdução, o serviço da fé é primário na vida apostólica da Companhia, enquanto a promoção da justiça surge como exigência absoluta deste serviço, principalmente frente às circunstâncias do mundo naquele momento histórico que convidava os jesuítas a uma autêntica e profunda conversão da mente e do coração. ${ }^{405}$ As congregações posteriores à $32^{\mathrm{a}}$ mantiveram o mesmo compromisso de repensar e atualizar a identidade do jesuíta pelo viés da fé e da justiça. Isto fica bem claro quando a $34^{\mathrm{a}} \mathrm{CG}$, em 1975 , afirmou:

O que vem a ser um jesuíta? É saber que, embora pecador, se é chamado a ser companheiro de Jesus como o foi Santo Inácio. (...) E o que significa ser companheiro de Jesus nos dias de hoje? É alistar-se, sob o estandarte da Cruz, na batalha crucial do nosso tempo: no combate pela Fé e no combate pela justiça que nele se inclui. ${ }^{406}$

A embora o tema do migrante e refugiado não apareça explicitamente no texto dos documentos da $32^{\mathrm{a}} \mathrm{CG}$ geral, a preocupação com a questão pode ser percebida nas entrelinhas quando o documento se refere aos pequenos, aos fracos e ao estrangeiro:

A missão da Companhia hoje é serviço presbiteral da fé, quer dizer, tarefa apostólica destinada a ajudar os homens a abrirem-se a Deus e a viverem segundo todas as dimensões e exigências do Evangelho, é vida purificada de todo o egoísmo e de toda a busca de vantagem própria, bem como de toda a forma de exploração do próximo. É vida que resplandece a perfeita justiça do Evangelho que dispõe não só a reconhecer e a respeitar os direitos e dignidade de todos os homens, especialmente dos mais pequenos e dos fracos, mas ainda a promover eficazmente tais direitos e tal dignidade, e a abrir-se generosamente a toda a miséria do próximo, seja ele estrangeiro ou inimigo por meio da reconciliação. ${ }^{407}$

Quase dez anos depois, num momento delicado da história da Companhia, a $33^{\mathrm{a}} \mathrm{CG}$ manteve a proposta da anterior de centralizar a missão na fronteira da fé e da justiça e convocou todos os jesuítas a prestarem atenção a alguns problemas

\footnotetext{
404 Congregação Geral XXXII, Decreto 4, n.2-3.

405 Congregação Geral XXXII, Decreto 4, Introdução, n.5.

406 Congregação Geral XXXII, Decreto 2, n.2.

407 Congregação Geral XXXII, Decreto 4, n.18.
} 
criticamente urgentes, ${ }^{408}$ entre eles " a penosa situação de milhões de refugiados, à procura de uma pátria permanente, problema que o padre Arrupe recomendara já à especial atenção da Companhia"409. Esta foi a primeira vez que o termo "refugiado" aparece nos textos das Congregações Gerais pós-concílio.

Mais recentemente, a $34^{\mathrm{a}}$, a $35^{\mathrm{a}}$ e a $36^{\mathrm{a}}$ Congregações Gerais sob a presidência dos Superiores Gerais Peter-Hans Kolvenbach, SJ, Adolf Nicolás, SJ, e Arturo Soza, SJ, respectivamente, vem adicionando, ao longo dos anos, elementos importantes ao conceito do SJR como foi inicialmente expresso por Arrupe. Nos documentos finais de cada uma delas, o SJR foi explicitamente mencionado. O êxito deste serviço se deve muito ao fato da consciência clara da Companhia acerca da missão e da ideia de que é sempre fundamental atender às necessidades dos refugiados, sejam elas de cunho físico, psicológico ou espiritual. $^{410}$

Durante os vinte e cinco anos em que dirigiu a Companhia de Jesus, Kolvenbach foi um guia incansável para a SJR e para a própria Companhia no que tange a seus serviços para com os migrantes e refugiados. Em uma carta aos jesuítas do mundo inteiro, em 1990, cinco anos antes da $34^{\mathrm{a}} \mathrm{CG}$, ele afirma claramente que fizera sua a convocação do padre Arrupe e das últimas Congregações Gerais no sentido de considerar a SJR "como expressão de (...) preocupação com os pobres e como um passo significativo em direção a (...) renovação pessoal e corporativa na disponibilidade, na mobilidade e na universalidade"411. No final da carta, Kolvenbach reitera que o serviço da Companhia aos refugiados é um teste real da disponibilidade dos jesuítas hoje e que "uma resposta generosa da companhia como corpo apostólico às necessidades dos refugiados que cruzam nossos caminhos e solicitam nossa ajuda fará com que nosso apostolado gere mais frutos, inclusive em outros campos". 412

Esta preocupação de Kolvenbach para com os migrantes e refugiados e seu comprometimento com o SJR se faz sentir novamente, anos depois, no Decreto 3 da Congregação por ele presidida:

408 Cf. disponível em: http://voluntariadopuentesjr.blogspot.com.br/2010/01/carta-del-padrekolvenbach-sj.html. Acesso em: 12 dez 2017. 409 Congregação Geral XXXIII, , Dec. 1, n.46, p.68.

410 Cf. GAVIN, P. Arrupe y la Fundación del Servício Jesuita a Refugiados. Jesuitas: Anuario da la Compañia de Jesús, 2016. Curia Generalicia de Compañia de Jesús, Roma, p.10.

${ }^{411}$ A tradução é nossa.

412 Cf. GAVIN, P. Arrupe y la Fundación del Servício Jesuita a Refugiados. Jesuitas: Anuario da la Compañia de Jesús, 2016. Curia Generalicia de Compañia de Jesús, Roma, p. 10 (a tradução é nossa). 
Atualmente, há no mundo mais de 45 milhões de pessoas refugiadas ou deslocadas de seus lugares de origem, das quais $80 \%$ são mulheres ou crianças. Acolhidos amiúde nos países mais pobres, enfrentam um empobrecimento crescente e a perda do sentido de vida e da cultura, com a consequente desesperança e desespero. O Serviço Jesuítico a Refugiados (JRS, Jesuit Refugee Service) acompanha muitos desses nossos irmãos e irmãs, servindo-os como companheiros e advogando sua causa num mundo que não se preocupa com eles. A CG 34 apela a todas as províncias para que apoiem o SJR de todas as formas possíveis e conclama a Companhia internacional a que some esforços às demais instituições e organismos internacionais para combater as injustiças que desarraigam as pessoas de sua terra $\mathrm{e}$ de suas famílias. ${ }^{413}$

Em 2008, a 35ª Congregação Geral, já presidida por Adolf Nicolás, ao citar cinco preferências globais que requerem uma atenção apostólica especial da parte da Companhia, lembrou que o padre Arrupe havia chamado a atenção da Companhia para o clamor dos refugiados e para o fato do fenômeno da migração forçada ter crescido dramaticamente. A Congregação, assim, reafirmou que a atenção às necessidades dos migrantes e refugiados deveria continuar sendo uma preferência apostólica da Companhia e que o SJR deveria continuar com seu estatuto e suas orientações atuais. ${ }^{414}$ No Decreto 3 da $35^{\text {a }} \mathrm{CG}$ encontramos:

Desde o momento em que o padre Arrupe chamou a atenção da Companhia para a situação dos refugiados, o fenômeno da migração, forçada por diferentes razões, aumentou drasticamente. Essas movimentações massivas de pessoas criaram grande sofrimento em milhões de pessoas. Por isso, esta Congregação reafirma que atender às necessidades dos migrantes, incluindo os refugiados, dos deslocados internos e das vítimas do tráfico de pessoas, continua a ser uma preferência apostólica da Companhia. Além disso, reafirmamos que o Serviço Jesuítas aos Refugiado mantenha a sua atual Carta e linhas orientadoras. ${ }^{415}$

Em 2010, dois anos depois da $35^{\mathrm{a}} \mathrm{CG}$, em mensagem ao SJR por ocasião de seu $30^{\circ}$ aniversário de fundação, o padre Nicolás reconheceu que surgiram novas formas de migração desde os tempos dos boat people vietnamitas que inspiraram o padre Arrupe e indicou fatores que são causas de novas formas de migração, como os desastres naturais e ambientais, a cobiça por minerais e recursos e o número crescente de refugiados urbanos. Ante esta nova realidade, padre Nicolás animava o SJR a promover a hospitalidade do Evangelho em ação e, ao mesmo

${ }^{413}$ Cf. Decretos da Congregação Geral XXXIV, Decreto 3, n.16, p.74.

${ }^{414}$ Cf. GAVIN, op. cit., p.10.

415 Decretos da 35ª Congregação Geral. Decreto 3, n.39. 
tempo, influenciar efetivamente e positivamente os valores das culturas onde atua. ${ }^{416} \mathrm{Na}$ ocasião, disse:

A hospitalidade é um valor profundamente humano e cristão que reconhece o clamor do outro, não porque "ele" ou "ela" sejam um membro da minha família, da minha comunidade, da minha raça ou da minha fé, mas simplesmente porque "ele" ou "ela" é um ser humano que merece ser bem-vindo e respeitado. É a virtude do bom samaritano que, em seu caminho, viu o "homem" necessitado e não um membro de outra raça. O JRS servindo aos refugiados é a tradução mesma da hospitalidade do Evangelho em ação. ${ }^{417}$

Em seu discurso aos membros da $35^{\mathrm{a}}$ Congregação Geral, o próprio papa

Bento XVI também fez uma referência específica ao trabalho da Companhia com os refugiados e ao papel de seu fundador nesta empreitada ${ }^{418}$ :

São inúmeras e dramáticas as situações de injustiça e pobreza no mundo de hoje, e é necessário que nos comprometamos a compreender e a combater, até o próprio coração do homem, as raízes profundas do mal, os pecados que o separam de Deus, sem nos esquecermos de ir ao encontro das necessidades mais urgentes, no espírito da caridade de Cristo. Retomando e desenvolvendo uma das últimas intuições, de longo alcance, do P. Arrupe, a vossa Companhia continua a comprometer-se de modo meritório, no serviço a favor dos refugiados que, muitas vezes, são os mais pobres entre os pobres, e que têm necessidade, não apenas de socorro material, mas também daquela mais profunda proximidade espiritual, humana e psicológica, que é própria do vosso serviço. ${ }^{419}$

Em 2016, a 36 CG geral, presidida por Arturo Soza, ao se referir à missão junto aos pobres e excluídos, coloca a situação dos migrantes e refugiados como uma das três formas de sofrimento que aparecem com mais insistência em muitas das Províncias e Regiões da Companhia:

O deslocamento de populações (refugiados, migrantes e deslocados internos). Face às atitudes de hostilidade para com estas pessoas, a nossa fé convida a Companhia a promover, onde quer que seja, uma mais generosa cultura de hospitalidade. A Congregação reconhece a necessidade de promover uma articulação internacional do nosso serviço aos migrantes e refugiados, encontrando formas de colaboração com o SJR. ${ }^{420}$

${ }^{416}$ Cf. GAVIN, P. Arrupe y la Fundación del Servício Jesuita a Refugiados. Jesuitas: Anuario da la Compañia de Jesús, 2016. Curia Generalicia de Compañia de Jesús, Roma, p.10.

417 NICOLÁS, Citação do Discurso proferido por ocasião do 30ำ aniversário da SJR. Anuario da la Compañia de Jesús, 2016. Curia Generalicia de Compañia de Jesús, Roma, p.7.

${ }^{418}$ Cf. GAVIN, op. cit., p.10.

419 Cf. Decretos da 35a Congregação Geral, Alocução do Santo Padre aos Membros da 35a Congregação Geral, p.287.

420 Cf. disponível em: https://mail.google.com/mail/u/0/\#inbox/16056896d5d9f70c?projector=1. Acesso em: 23 jan 2018. 
Dois meses depois de encerrada a $36^{\mathrm{a}} \mathrm{CG}$, padre Soza voltou a mostrar o comprometimento dos jesuítas com o tema dos refugiados, quando se dirigiu aos próprios, a voluntários e amigos da SJR, numa visita ao Centro Astalli, em Roma, no contexto do Dia do Refugiado, dizendo que "as raízes da Europa estão no respeito aos direitos humanos; é preciso promover um movimento de cidadãos europeus porque quem está no governo interpreta sempre interesses específicos de partidos e certas ideologias" ${ }^{21}$. E, na ocasião, ainda propôs:

Serve uma política de acolhimento e o único modo de impô-la é pressionando a partir de "baixo", do povo. Entendo que alguns defendam posições de fechamento ou rechaço, mas acredito que todos temos um coração e podemos ver as pessoas, os estrangeiros, como homens e mulheres como nós, e não como ameaças. Se as crianças são as primeiras a acolher seus coetâneos, então toda a sociedade deve voltar a ser "criança", indo ao encontro dos outros. ${ }^{422}$

Padre João Renato Eidt, atual Superior da Província do Brasil, comentando a $36^{a}$ CG, um mês antes de seu início, deixa claro a importância da SJR na missão da Companhia de Jesus hoje:

São muitos os desafios que se apresentam para a Companhia nos nossos dias. Para discerni-los, os jesuítas congregados precisam conhecer, profundamente, a realidade eclesial, social, política e econômica em que vivemos. Fazem parte dela as diversas formas de intolerância que se manifestam em todo o mundo. Como consequência, temos o drama, cada vez maior, dos refugiados e a necessidade de acolhimento. São muito claras as grandes desigualdades sociais e econômicas produzidas pela ambição do lucro e do poder. São evidentes, também, as injustiças decorrentes dessa situação e das vidas ceifadas pelas guerras. A escolha do novo Padre Geral para governar-nos nos próximos anos, reveste-se de significado muito especial para todos nós. ${ }^{423}$

\section{4}

\section{Considerações Finais do 4 ำ capítulo}

Este momento de graça e abertura ao mundo que a Igreja está vivendo sob o comando de papa Francisco parece ser o momento propício para que tanto os cristãos como todas as pessoas de boa vontade se sintam convidadas e estimuladas a se engajarem na luta em prol dos seres humanos desalojados e colocados em

\footnotetext{
${ }^{421} \mathrm{Cf}$. disponível em: http://br.radiovaticana.va/news/2017/01/14/superior_dos_jesu\%C3\%ADtas_ visita_refugiados_e_prop\%C3\%B5e_iniciativa_/1285619. Acesso em: $15 \mathrm{dez} 2017$.

${ }^{422} \mathrm{Cf}$. disponível em: http://br.radiovaticana.va/news/2017/01/14/superior_dos_jesu\%C3\%ADtas _ visita_refugiados_e_prop\%C3\%B5e_iniciativa_/1285619. Acesso em: $15 \mathrm{dez} 2017$.

${ }_{423}$ Disponível em: http://www.jesuitasbrasil.com/newportal/wp-content/uploads/2016/09/28 ${ }^{\text {a }}$ Edição.pdf. Acesso em: $16 \mathrm{dez} 2016$.
} 
situação de extrema vulnerabilidade em função de interesses egoístas de um grupo pequeno e poderoso e a omissão dos demais. O mundo não pode mais fechar os olhos a esta realidade chocante de milhares de pessoas se movimentando de país em país, nas condições mais adversas possíveis, arriscando diariamente sua vida e de suas famílias em busca de um acolhimento, e de outras tantas confinadas a acampamentos extremamente precários, muitas vezes em condições sub-humanas e sem direito nenhum à cidadania.

Os refugiados são vítimas inocentes de conflitos que não lhes dizem respeito. Não tiveram voz nenhuma nos acontecimentos que geraram o desastre humanitário que estão vivendo. Eles são simplesmente seres humanos obrigados a migrar, para defender suas famílias, dar uma possibilidade de futuro para seus filhos, para encontrar um lugar onde se sintam seguros, encontrem paz e possam viver.

A Companhia de Jesus está comprometida com esta fronteira há mais de 35 anos e atua em favor dos refugiados e migrantes através do trabalho desenvolvido pelo Serviço Jesuíta Refugiados. O SJR, através de seus programas educacionais, de seus projetos sociais, de seu acompanhamento pastoral, de sua estrutura administrativa, na busca de novos parceiros, quer encontrar a melhor forma de atuar nesta fronteira e ter êxito em seu esforço de acompanhar e apoiar os refugiados e migrantes em sua luta por uma vida digna.

Seguindo a intuição de Arrupe, a Companhia de Jesus não vê o trabalho junto aos migrantes e refugiados somente como consequência de uma crise humanitária e, sim, como resposta à convocação de aggiornamento aos sinais dos tempos feita pelo Concílio Vaticano II. Como se pode perceber pelos textos das Congregações Gerais da Companhia de Jesus pós-conciliares, há, entre os jesuítas, o esforço de atualizar a missão para as necessidades do mundo contemporâneo. O trabalho com os migrantes é parte deste esforço.

O papa Francisco, também jesuíta, e por isso imbuído dos mesmos valores da Companhia, é extremamente sensível ao tema e colocou os migrantes e refugiados no centro do pensamento e do discurso da Igreja. Para ele, a crise dos refugiados é uma crise de todos nós e, por isso, conclama todos a acolher, proteger, promover e integrar estas pessoas. Para tanto, propõe uma "cultura do encontro" no lugar da globalização da indiferença e das políticas de "rejeição e medo". Para o papa não existe crise de refugiados e sim uma crise de 
solidariedade, de recusa de homens e mulheres em abrirem suas portas ao bater daqueles que não têm um lar e o fechamento de seus corações aos irmãos e irmãs em necessidade.

A missão da Companhia de Jesus, através do SJR, é ir "além de nossas seguranças e certezas, tendo sempre em frente a si própria a vida e a esperança das pessoas que encontramos pela vida, que, com urgência, desejam dizer para nós e ao mundo: 'Eu era estrangeiro e vós me acolhestes'(Mt 25,35)". ${ }^{424}$ 


\section{5 \\ Conclusão}

A partir do percurso feito nesta dissertação, pela espiritualidade inaciana, pela história recente da Companhia de Jesus e sobre o pontificado de Francisco, o primeiro papa jesuíta, podemos chegar a algumas conclusões pertinentes acerca da missão e do carisma da Companhia de Jesus e, também, do nosso papel como cristãos no mundo de hoje.

A missão dos jesuítas junto às fronteiras onde se encontram os esquecidos da sociedade tem raízes espirituais muito profundas e sólidas que chegam à Sagrada Escritura. Estas raízes estão presentes nas intuições de Inácio de Loyola e de tantos outros homens que deixaram suas marcas na Companhia de Jesus, entre eles Jorge Mario Bergoglio e Pedro Arrupe. Tais raízes são também o pano de fundo dos documentos da instituição e dos escritos de jesuítas que chegam a nós através dos séculos de existência da Companhia.

Em Genesis, quando Deus questiona Caim e pergunta “Onde está teu irmão Abel?" (Gn 4,9), esta pergunta é, de fato, dirigida a toda a humanidade e nos compromete frente a todos os que sofrem e estão perdidos. O Deus da Bíblia sempre se mostra particularmente preocupado com os que estão à margem, lá indicados como o estrangeiro, os órfãos e as viúvas (S1 146,9; Dt 10,18, Zc 7,910) e que hoje podem ser irdentificados como os rejeitados por uma política econômica mundial que atende somente as necessidades de uma ínfima parte da sociedade. Por mais que o mundo em que vivemos nos indique caminhos de fechamento e egoísmo, como cristãos e pessoas de boa-vontade a pergunta que Deus fez a Caim continua a ecoar em nossas consciências. Não é mais possível fechar os olhos a tanto sofrimento que nos cerca, como no caso dos migrantes e refugiados, que remete mais diretamente à defesa de Deus em prol do estrangeiro. A nossa fé exige uma resposta à pergunta de Deus e a Companhia de Jesus tem tentado dá-la através de seu carisma missionário. Mas este é também dever de todos nós cristãos.

Não existe exercício da fé que não esteja atrelado à diaconia da justiça. Esta consciência, que perpassa a vida da Companhia de Jesus e que pode ser percebida através de suas Constituições e também das opções recentes por ela tomadas, 
também tem sua origem na Sagrada Escritura que é toda perpassada por esta mesma compreensão.

O Deus da Bíblia, que nos cria e salva, é um Deus justo e misericordioso ( $\mathrm{Sl}$ 140,12-13). No Primeiro Testamento, ele cuida de seu povo (Is 40,11), adverte-o (S1 80,16), mas se compadece de seu sofrimento (S1 145,9; Is 49;13; Zc 7,9-10) e, para restaurar sua vida e dignidade, envia seu próprio filho ao mundo como o Messias (Jo 13,17). Da mesma forma, conclama a toda a humanidade a fazer o mesmo, praticando a justiça para com todos, principalmente os mais pequeninos (Dt 1,17; Pv 31, 8- 9).

No Segundo Testamento, o exercício da justiça atrelada à fé e à misericórdia para com os desfavorecidos e esquecidos é determinante para Jesus Cristo (Lc 10,26-28; Mt 3,36). Isto fica bem claro em suas parábolas, discursos e atitudes. O próprio Jesus, quando, segundo Lucas, inicia sua vida pública, lê as seguintes palavras do Primeiro Testamento, relacionando-as a si mesmo:

Ele foi a Nazara, onde fora criado, e, segundo seu costume, entrou no dia de sábado na sinagoga e levantou-se para fazer a leitura. Foi-lhe entregue o livro do Profeta Isaías, desenrolou-o, encontrando o lugar onde estava escrito: "O Espírito do Senhor está sobre mim, porque ele me consagrou pela unção para evangelizar os pobres, enviou-me para proclamar a libertação dos presos e aos cegos a recuperação da vista, para restituir a liberdade aos oprimidos e para proclamar um ano de graça do Senhor". (Lc 4,16-18)

Outro exemplo bíblico bem emblemático desta relação entre fé e justiça é a parábola do Bom Samaritano, onde o estrangeiro, ele mesmo à margem da sociedade, é aquele que socorre o desconhecido em necessidade extrema, depois deste ter sido ignorado pelo sacerdote, o representante da religião, e pelo levita, o homem responsável pelas leis. Jesus não somente enxerga, no exercício de sua missão, a luta pela justiça, como também mostra, nesta parábola, que fé sem práxis é vazia. Ao fim da parábola abaliza a ação do samaritano, um estrangeiro, em detrimento da atitude do sacerdote e do levita e conclama todos a seguirem seu exemplo: "Vai, e também tu, faze o mesmo." (Lc 10, 37)

Assim como as do Pai, no Primeiro Testamento, ao se dirigir a Caim, as palavras de Jesus, na sinagoga, também se dirigem a nós e exigem um comprometimento de nossa fé com a justiça social.

A prioridade do exercício da justiça social também é determinante no discurso sobre o Juízo Final, quando os convidados a sentarem-se à direita do Pai 
são aqueles que praticaram a justiça para com os marginalizados (Mt 25, 39-40). $\mathrm{Na}$ visão de Jesus, atender as necessidades dos irmãos mais esquecidos é, na realidade, atender ao próprio Cristo, e se transforma, nesta perícope, em critério de salvação para todos os homens e mulheres de todos os tempos.

Uma outra leitura importante para os dias de hoje, que podemos tirar da descrição do Juízo Final por Mateus, é que só enxergando no irmão que sofre o próprio Cristo teremos condições reais de fazer a experiência de viver esta fé proposta pela Sagrada Escritura, que se confunde com justiça e misericórdia. A mística judaico-cristã proposta pela Bíblia é uma mística que só admite uma verdadeira contemplação de Deus se esta se der através do encontro com o outro, principalmente o irmão que sofre. Segundo Maria Clara Bingemer, "a mística cristã, se contempla Deus, só pode e só tem possibilidade de contemplá-lo pelo caminho da alteridade (...) o rosto do outro, do próximo é o único caminho que faz com que o Deus contemplado não seja uma projeção enganosa, uma fantasia alienante que afasta da realidade que clama por justiça" ${ }^{425}$.

É a partir desta intuição, usando o viés do serviço prestado pela Companhia de Jesus, que esta dissertação pretendeu abordar a questão dos migrantes e sua prioridade e relevância frente a tantas outras questões que tocam a consciência dos cristãos e demais pessoas de boa-vontade. Como, nós cristãos, devemos nos posicionar diante do mundo, frente a esta sociedade desumana que estamos construindo e que descarta povos e populações inteiras como refugo que incomoda? Estes migrantes exigem, como seres humanos, criaturas amadas e preferidas de Deus, um envolvimento de todos numa reação concreta a esta sociedade que os destrói.

A situação destes milhões de pessoas vagando pelo planeta, seja pelos mares e montanhas da Europa, seja pelos desertos norte-americanos, pelas florestas quentes da América do Sul e pelas geladas do Canadá, ou mesmo por outros lugares com menos visibilidade, que nem chegam ao nosso conhecimento, clama por uma solução. Elas caminham sem destino, sem um porto seguro a chegar, sem esperança, nos questionando em nossa própria condição antropológica: somos todos migrantes e estrangeiros buscando a terra prometida por Deus, tão ansiada e desejada por nós. O nossa própria experiência de transitoriedade, de sermos

425 Disponível em: http://nucleodememoria.vrac.puc-rio.br/primeiro_site/dhc/textos/mariaclara bingemer.pdf. Acesso em: 24 jan 2018. 
peregrinos nesta vida rumo ao cumprimento da promessa de Jesus Cristo, deveria nos fazer voltar a atenção para a causa destas pessoas e perceber, na acolhida do migrante e refugiado e na superação da estranheza, do medo e da distância que nos separa deles, o cumprimento do $2^{\circ}$ mandamento: "Amar ao próximo como a ti mesmo". Só teremos condições de enxergá-los como irmãos, na medida em que percebermos que caminhamos juntos para a terra prometida, onde haverá espaço para todos.

Para além dos questionamentos antropológicos acerca da nossa própria condição de refugiados nesta terra, a situação destas pessoas também põe em cheque os valores éticos basilares da sociedade ocidental. Entre eles podemos citar a questão da família, tão central para o atual papa (vide a Exortação Apostólica Sinodal Amoris Laeticia). No bojo do descaso em relação aos migrantes e refugiados, se encontram milhares de famílias que estão sendo destruídas e separadas não só pela violência encontrada na busca de um refúgio em condições absolutamente desumanas e cruéis, como também pelas leis de imigração igualmente cruéis e restritivas que não consideram o sofrimento das pessoas por elas atingidas. Neste mesmo bojo de descaso, está também o drama de pais de família que têm a difícil decisão de arriscar tudo, inclusive a vida de todos, em prol de um futuro melhor. Estão aí também as mulheres e homens vitimizados por questões de gênero, crianças com infâncias roubadas, idosos abandonados à própria sorte e culturas destruídas, gerando danos irreversíveis à sociedade e à humanidade como um todo.

Até quando seremos bombardeados por notícias de crianças chegando sozinhas à Europa, vindas de regiões em guerra, famílias destruídas em tentativas desesperadas de conseguir um lugar para viver, pais de famílias e jovens morrendo de fome e exaustão durante travessias de desertos, pais sendo deportados simplesmente por serem estrangeiros, deixando para trás famílias destruídas e sem condição de sobrevivência econômica digna, sem tentarmos dar uma resposta concreta à pergunta que Deus nos faz no Gênesis?

Nosso objetivo, com esta dissertação, foi mostrar como a Companhia de Jesus, através de sua índole missionária, entre erros e acertos, tem levado jesuítas e pessoas de boa-vontade a superar diferenças e estender as mãos para estes irmãos em situação de extremo risco, dando sua resposta a Deus, vivendo verdadeiramente o seguimento de Jesus Cristo, que exige o comprometimento 
com o binômio fé e justiça e com uma verdadeira práxis em favor dos pequeninos e esquecidos. Também enfatizamos, nesta dissertação, que o exemplo da Companhia de Jesus pode apontar caminhos para aqueles que se sintam chamados, ajudando-os também a encontrar formas de responder à pergunta de Deus e assim participar, já agora, da construção do Reino de Deus, lutando por um mundo mais justo em que haja espaço para todos levarem uma vida digna e tornarmos nossa sociedade realmente humana. 


\section{6 \\ Referências bibliográficas}

ABU-SEIF. M. Dialogo interreliososo: esperanza y miedo. Jesuitas: Anuario da la Compañia de Jesús, 2016. Curia Generalicia de Compañia de Jesús, Roma, Itália. (P. 36-41),

AGUNDEZ, U. V. El Proyecto de Renovación da la Compañia de Jesus (19652007). Santander e Bilbao: Mensajero e Sal Terrae, 2011.

ALTEMAYER JR, F. Os muitos partos do bispo de Roma. In: PASSOS, J. D.; SOARES, A. M. L. Francisco: renasce a esperança. São Paulo: Paulinas, 2013. p.104-19.

AQUINO Jr., F. Os pobres e a pobreza como carisma fundante da Igreja de Jesus. In: PASSOS, J. D.; SOARES, A. M. L. Francisco: renasce a esperança. São Paulo: Paulinas, 2013. p.210-22.

BALLEIS, P. Um servicio humano, pedagógico y espiritual. Jesuitas: Anuario da la Compañia de Jesús, 2016. Curia Generalicia de Compañia de Jesús, Roma, Itália. p.12-15.

BARRY, W. A.; DOHERTY, R. G. Contemplativos em ação: o caminho do jesuíta. São Paulo: Loyola, 2005.

BINGEMER, M. C. L. Esperança de futuro para a Igreja. In: PASSOS, J. D.; SOARES, A. M. L. Francisco: renasce a esperança. São Paulo: Paulinas, 2013. p.238-50.

O mistério e o mundo: Paixão por Deus em tempos de descrença. Rio de Janeiro: Rocco, 2013.

BRAGA, D. Serviço Jesuíta a migrantes e refugiados: Obra de Misericórdia. Itaici: revista de espiritualidade inaciana. n.103. p.5-18.

BRIGUENTI, A. Uma instituição em crise em uma sociedade em crise. In: PASSOS, J. D.; SOARES, A. M. L. Francisco: renasce a esperança. São Paulo: Paulinas, 2013. p.28-45.

CONSTITUIÇÕES DA COMPANHIA DE JESUS e normas complementares. São Paulo: Loyola, 2004.

CONGREGAÇÃO GERAL XXXI: Documentos. 1967. Impressão privada da Companhia de Jesus.

CONGREGAÇÃO GERAL XXXII: Decretos. Braga: Gráficas de Barbosa \& Xavier, 1975.

CONGREGAÇÃO GERAL XXXIII. Decretos e Documentos. São Paulo: Loyola, 1984. 
COSTA, A. S. Quero que tu nos sirva: a mística inaciana de serviço solidário aos pobres. Itaici: revista de espiritualidade inaciana. 2015, p.5-20.

DECRETOS DA CONGREGAÇÃO GERAL XXXIV: XV após a Restauração da Companhia. Col. Documenta S.J., 13. São Paulo: Loyola, 1996.

DECRETOS DA $35^{\mathrm{a}}$ CONGREGAÇÃO GERAL DA COMPANHIA DE JESUS: $16^{\text {a }}$ desde a Restauração da Companhia. São Paulo: Loyola, 2008.

DECRETOS DA $36^{\mathrm{a}}$ CONGREGAÇÃO GERAL: $17^{\mathrm{a}}$ desde a restauração da Companhia de Jesus. São Paulo: Loyola, 2017.

ECHANIZ, I. Paixão e glória: história da Companhia de Jesus em corpo e alma. Tomo I: Primeira Primavera (1529-1581). São Paulo: Loyola, 2006.

Paixão e glória: história da Companhia de Jesus em corpo e alma. Tomo IV: Segunda Primavera (1814-1965). São Paulo: Loyola, 2006.

EXERCÍCIOS ESPIRITUAIS DE SANTO INÁCIO. São Paulo: Loyola, 2006.

FERNANDES, S. Avivar la confianza mediante la educación. Jesuitas: Anuario da la Compañia de Jesús. Roma, Itália. p.26-8.

FRANCISCO. Evangelii Gaudium. São Paulo: Paulinas, 2013.

FRANCISCO. Laudato Si. São Paulo: Paulinas, 2015.

GASQUES, J. Coisas do papa Francisco: primeiro papa latino-americano. São Paulo: Loyola, 2015.

GAVIN, K. P. Arrupe y la Fundación del Servicio Jesuita a Refugiados. Jesuitas: Anuário de la companhia de Jesús, 2016. Roma, p.8-11.

GONZÁLEZ-QUEVEDO, L. O novo rosto da Igreja: papa Francisco. 2.ed. São Paulo: Loyola, 2015.

Quo vadis. In: Convergência, dez 2017.

HUMMES, C. Grandes metas do papa Francisco. São Paulo: Paulus, 2017.

IVERN, F. A missão da Companhia de Jesus da Congregação Geral 31 até os nossos dias. Itaici: revista de espiritualidade inaciana. n.105, 2016, p.5-18.

The Future of Faith and Justice: a critical review of Decree Four. Studies in the Spirituality of Jesuits. n.5, v.XIV, 1982.

JOSAPHAT, C. Uma reforma evangélica na plena fidelidade criativa ao Vaticano II. In: PASSOS, J. D.; SOARES, A. M. L. Francisco: renasce a esperança. São Paulo: Paulinas, 2013. p.222-37.

KLEIN, L. F. Jesuítas: Carisma e Missão. Itaici: revista de espiritualidade inaciana. n.105, p.33-44.

LOPES, R. S. S. Discernimento inaciano: a liberdade humana respondendo a Deus. Dissertação de Mestrado, Departamento de Teologia, PUC-Rio, 2015. 
MARTINEZ, B. Educacion a todos los niveles. Jesuitas: Anuario da la Compañia de Jesús. Roma, p.23-5.

MIRANDA, M. de F. A reforma de Francisco: fundamentos teológicos. São Paulo: Paulinas, 2017.

. Francisco: papa e jesuíta. In: PASSOS, J. D.; SOARES, A. M. L. Francisco: renasce a esperança. São Paulo: Paulinas, 2013. p.134-44.

PALACIO, C. Homilia da missa de ação de graças e oração pelo papa Francisco. Itaici: revista de espiritualidade inaciana. n.91, p.5-8.

Recurso a Jesus Cristo e recomposição da missão da Companhia de Jesus (1965-2015). Itaici: revista de espiritualidade inaciana. n.99, 2015, p.21-35.

"Fazer-se ao largo" na vida e na missão. Aproximação hermenêutica à Congregação Geral 36. Itaici: revista de espiritualidade inaciana. n.107, 2017, p.5-17.

PASSOS, J. D.; SOARES, A. M. L. Francisco: Renasce a Esperança. São Paulo: Paulinas, 2013. p. 18-25.

SANTO INÁCIO. O Relato do Peregrino. Trad. R. Paiva, SJ. São Paulo: Loyola, 2006. (Nova edição do título anterior: Autobiografia de Santo Inácio de Loyola).

SPADARO, A. Entrevista exclusiva do papa Francisco ao pe. Antonio Spadaro, SJ. São Paulo: Paulus e Loyola, 2013.

SOUZA, L. A. G.; RIBEIRO, L. Obstáculos e possibilidades para criar um clima de reformas: a responsabilidade de um bispo de Roma que vem da periferia. In: PASSOS, J. D.; SOARES, A. M. L. Francisco: renasce a esperança. São Paulo: Paulinas, 2013. p. 177-88.

VALETINI, D. Prefácio. In: PASSOS, J. D.; SOARES, A. M. L. Francisco: renasce a esperança. São Paulo: Paulinas, 2013. p.10-7.

VELLA, D. El acompanamiento como piedra angular. Jesuitas: Anuario da la Compañia de Jesús. Roma, p.16-9. 


\section{Sites consultados:}

www.biografiasyvidas.com/biografia/a/arrupe.htm

www.jesuitasbrasil.com/newportal/2016/12/15/discurso-do-papa-francisco-aosmembros-da-36a-cg/

www.ihu.unisinos.br/560736-jesuitas-reunem-se-em-esforco-para-apreender-oefeito-francisco

www.ihu.unisinos.br/564539-periferia-e-fronteiras-intuicao-mais-forte-dateologia-da-libertacao-entrevista-com-arturo-sosa

www.ihu.unisinos.br/images/stories/cadernos/teopublica/011 cadernosteologiapubl ica.pdf.

agape.usuarios.rdc.puc-rio.br/amai/osegredodopapajesuita.pdf.

domtotal.com/colunas/detalhes.php?artId=3497

www.ihu.unisinos.br/539064-papa-francisco-jesuíta-e-então

www.ihu.unisinos.br/78-noticias/560975-o-que-o-papa-francisco-ja-disse-aosjesuitas-artigo-de-elias-royon

books.google.com.br/books?isbn=8515042134

leonardoboff.wordpress.com/2017/04/08/o-que-significa-uma-igreja-em-saidasegundo-o-papa-francisco/

www.ihu.unisinus.br/518772-esta-e-a-intervencao-magistral-do-cardeal-

bergoglio-no-pre-conclave

w2.vatian.va/contente/francesco/pt/speeches/2013/june/documents/papafrancesco_20110614_lacivilta-cattolica.html

wa.vatican.va/contente/francesco/pt.speeches/2013/march/documents/papafrances co_2013022_corpo-diplommatico.html

www.jesuitasbrasil.com/newportal/2017/09/13/livro-de-professor-de-teologia-elancado-na-unicap

www.unicap.br/assecom1/livro-de-professor-de-teologia-aborda-a-relacao-entrefe-igreja-e-sociedade/

www.rj.gov.br/web/imprensa/exibeconteudo?article-id=1692458

www.maxwell.vrac.puc-rio.br/25797/25797_4.PDF

www.ihu.unisinos.br/78-noticias/566923-as-vezes-a-igreja-caiu-em-uma-teologiado-pode-e-do-nao-pode

www.ihu.unisinos.br/520830-sejam-pessoas-livres-a-audiencia-do-papa-aosestudantes-das-escolas-jesuitas

www.ihu.unisinos.br/78-noticias/555648-os-teologos-malditos-e-o-papafrancisco-artigo-de-victor-codina

w2.vatican.va/.../papa-francesco_20140823_messaggio-meeting-amiciziapopoli.html 
www.ihu.unisinos.br/noticias/521786-qadao-onde-estas-caim-onde-esta-o-teuirmao-o-discurso-de-francisco-em-lampedusa

www.ihu.unisinos.br/espiritualidade/comentario-do-evangelho/78-

noticias/573763-a-atualidade-do-servico-jesuita-aos-refugiados-nos-37-anos-dasua-fundacao

www.ihuonline.unisinos.br/index.php?option $=$ com_content $\&$ view $=$ article $\& i d=38$ $70 \&$ secao $=3$

agenciabrasil.ebc.com.br/internacional/noticia/2016-06/papa-francisco-pede-quepessoas-escutem-e-acolham-os-refugiados

www.ufjf.br/ladem/2015/06/17/mundo-vive-maior-crise-de-refugiados-desde-asegunda-guerra-diz-anistia/

migramundo.com/lampedusa-a-porta-da-europa/

www.iom.int/

Www.acnur.org/portugues/recursos/estatisticas/

www.ihu.unisinos.br/78-noticias/559581-novo-dicasterio-papa-se-ocupara-dosmigrantes

oglobo.globo.com/mundo/lampedusa-uma-ilha-entre-extremos-10532355

www.ihu.unisinos.br/171-noticias/noticias-2013/521701-papa-francisco-visitalampedusa-o-inferno-no-mediterraneo

w2.vatican.va/content/francesco/pt/motu_proprio/documents/papa-francescomotu-proprio_20160817_humanam-progressionem

www.agencia.ecclesia.pt/noticias/vaticano/vaticano-papa-cria-estrutura-parapromover-desenvolvimento-humano-integral/

www.ihu.unisinos.br/78-noticias/559581-novo-dicasterio-papa-se-ocupara-dosmigrantes

www.publico.pt/2013/07/08/mundo/noticia/papa-francisco-escolhe-lampedusapara-primeira-viagem-do-seu-pontificado-1599582

migramundo.com/lampedusa-a-porta-da-europa/

oglobo.globo.com/mundo/lampedusa-uma-ilha-entre-extremos-10532355

w2.vatican.va/content/francesco/pt/homilies/2013/documents/papa-

francesco_20130708_omelia-lampedusa.html

w2.vatican.va/content/francesco/pt/speeches/2014/november/documents/papafrancesco_20141125_strasburgo-parlamento-europeo.html

w2.vatican.va/content/francesco/pt/speeches/2014/november/documents/papafrancesco_20141125_strasburgo-consiglio-europa.html

g1.globo.com/jornal-nacional/noticia/2016/04/papa-leva-tres-familias-derefugiados-sirios-para-roma.html

w2.vatican.va/content/francesco/pt/motu_proprio/documents/papa-francescomotu-proprio_20160817_humanam-progressionem

www.agencia.ecclesia.pt/noticias/vaticano/vaticano-papa-cria-estrutura-parapromover-desenvolvimento-humano-integral/ 
www.ihu.unisinos.br/78-noticias/559581-novo-dicasterio-papa-se-ocupara-dosmigrantes

w2.vatican.va/content/francesco/pt/messages/migration/documents/papafrancesco_20170815_world-migrants-day-2018.html

www.missaonspaz.org/single-post/2017/02/22/Papa-Francisco-faz-discurso-naabertura-do-VI-F\%C3\%B3rum-Migra\%C3\%A7\%C3\%A3o-e-Paz-em-Roma

www.celam.org/observatorio/docs/ANALISIS_COYUNTURA_Ma_Clara_17031 7.pdf

w2.vatican.va/content/francesco/pt/speeches/2017/february/documents/papafrancesco_20170221_forum-migrazioni-pace.html

www.ihu.unisinos.br/78-noticias/561012-servico-jesuita-aos-refugiadosacompanhando-servindo-e-defendendo

en.jrs.net/Profile?PID=135

www.historylearningsite.co.uk/vietnam-war/vietnamese-boat-people/

www.jrsportugal.pt/wp-content/uploads/pdf/carta-pedro-arrupe.pdf

www.itaici.org.br/santos-da-companhia-de-jesus/27/14-11-sao-jose-pignatelli1737-1811

w2.vatican.va/content/francesco/pt/speeches/2013/september/documents/papafrancesco_20130910_centro-astalli.html

www.acnur.org/portugues/recursos/estatisticas/

en.jrs.net/news_detail?TN=NEWS-20171113051504has

www.ihu.unisinos.br/78-noticias/561012-servico-jesuita-aos-refugiadosacompanhando-servindo-e-defendendo.

www.ihu.unisinos.br/78-noticias/551413-pedro-arrupe-cronologia-de-um-profeta voluntariadopuentesjr.blogspot.com.br/2010/01/carta-del-padre-kolvenbachsj.html.

br.radiovaticana.va/news/2017/01/14/superior_dos_jesu\%C3\%ADtas_visitarefugi ados_e_prop\%C3\%B5e_iniciativa_/1285619.

cnbbne2.org.br/papa-divulga-mensagem-para-o-dia-mundial-da-paz-2018/

w2.vatican.va/content/francesco/pt/messages/peace/documents/papafrancesco_20171113_messaggio-51giornatamondiale-pace2018.html

nucleodememoria.vrac.puc-

rio.br/primeiro_site/dhc/textos/mariaclarabingemer.pdf

noticias.uol.com.br/ultimas-noticias/efe/2017/06/19/a-perigosa-tarefa-deatravessar-a-fronteira-mexico-eua.htm.

noticias.uol.com.br/ultimas-noticias/efe/2017/06/19/a-perigosa-tarefa-deatravessar-a-fronteira-mexico-eua.htm.

theintercept.com/2017/11/27/haitianos-fogem-dos-eua-e-canada-se-prepara-parauma-nova-onda-de-refugiados/ 
http://www.ihu.unisinos.br/78-noticias/568256-dez-anos-depois-de-aparecidacarriquiry-ali-nasceu-o-pontificado-de-bergoglio

http://www.ihuonline.unisinos.br/artigo/5919-juan-carlos-scannone-3 